\title{
Fertility and early pregnancy outcomes after conservative treatment for cervical intraepithelial neoplasia (Review)
}

Kyrgiou M, Mitra A, Arbyn M, Paraskevaidi M, Athanasiou A, Martin-Hirsch PPL, Bennett P, Paraskevaidis $\mathrm{E}$

Kyrgiou M, Mitra A, Arbyn M, Paraskevaidi M, Athanasiou A, Martin-Hirsch PPL, Bennett P, Paraskevaidis E. Fertility and early pregnancy outcomes after conservative treatment for cervical intraepithelial neoplasia. Cochrane Database of Systematic Reviews 2015, Issue 9. Art. No.: CD008478. DOI: 10.1002/14651858.CD008478.pub2.

www.cochranelibrary.com 
TABLE OF CONTENTS

ABSTRACT 1

PLAIN LANGUAGE SUMMARY

SUMMARY OF FINDINGS

BACKGROUND

OBJECTIVES

METHODS

RESULTS

Figure 1.

Figure 2.

Figure 3.

Figure 4.

Figure 5.

Figure 6.

DISCUSSION

AUTHORS' CONCLUSIONS

ACKNOWLEDGEMENTS

REFERENCES

CHARACTERISTICS OF STUDIES

DATA AND ANALYSES

Analysis 1.1. Comparison 1 Fertility outcomes, Outcome 1 Total pregnancy rates.

Analysis 1.2. Comparison 1 Fertility outcomes, Outcome 2 Pregnancy rate in women with intention to conceive. ...................

Analysis 1.3. Comparison 1 Fertility outcomes, Outcome 3 Conception within 0-3 months (excisional treatment versus no treatment).

Analysis 1.4. Comparison 1 Fertility outcomes, Outcome 4 Conception within 0-6 months (excisional treatment versus no treatment).

Analysis 1.5. Comparison 1 Fertility outcomes, Outcome 5 Conception within 0-9 months (excisional treatment versus no treatment).

Analysis 1.6. Comparison 1 Fertility outcomes, Outcome 6 Conception within $0-12$ months (excisional treatment versus no treatment).

Analysis 1.7. Comparison 1 Fertility outcomes, Outcome 7 Conception within 0-24 months (excisional treatment versus no treatment).

Analysis 1.8. Comparison 1 Fertility outcomes, Outcome 8 Conception $>12$ months (treatment versus no treatment). .............. Analysis 1.9. Comparison 1 Fertility outcomes, Outcome 9 Conception $>12$ months (treatment versus no treatment). .............. Analysis 1.10. Comparison 1 Fertility outcomes, Outcome 10 Conception $>12$ months (colposcopy only versus no treatment). . Analysis 1.11. Comparison 1 Fertility outcomes, Outcome 11 Conception $>12$ months (treatment versus colposcopy only). .... Analysis 1.12. Comparison 1 Fertility outcomes, Outcome 12 Conception $>12$ months (treatment versus colposcopy only). .... Analysis 1.13. Comparison 1 Fertility outcomes, Outcome 13 Conception $>36$ months (treatment versus no treatment). ......... Analysis 2.1. Comparison 2 Early pregnancy outcomes, Outcome 1 Miscarriage rates (treatment versus no treatment). .......... Analysis 2.2. Comparison 2 Early pregnancy outcomes, Outcome 2 Miscarriage rates (treatment versus no treatment). .......... Analysis 2.3. Comparison 2 Early pregnancy outcomes, Outcome 3 1st trimester Miscarriage rates (treatment versus no treatment).

Analysis 2.4. Comparison 2 Early pregnancy outcomes, Outcome 4 2nd trimester miscarriage rates (treatment versus no treatment).

Analysis 2.5. Comparison 2 Early pregnancy outcomes, Outcome 5 Ectopic pregnancy (treatment versus no treatment). ........ Analysis 2.6. Comparison 2 Early pregnancy outcomes, Outcome 6 Ectopic pregnancy (treatment versus no treatment). ......... Analysis 2.7. Comparison 2 Early pregnancy outcomes, Outcome 7 Molar pregnancy rates (treatment versus no treatment). ... Analysis 2.8. Comparison 2 Early pregnancy outcomes, Outcome 8 Termination of pregnancy rates (Treatment versus no treatment).

Analysis 2.9. Comparison 2 Early pregnancy outcomes, Outcome 9 Termination of pregnancy rates (treatment versus no treatment).

APPENDICES

WHAT'S NEW 
[Intervention Review]

\section{Fertility and early pregnancy outcomes after conservative treatment for cervical intraepithelial neoplasia}

Maria Kyrgiou ${ }^{1}$, Anita Mitra ${ }^{2}$, Marc Arbyn ${ }^{3}$, Maria Paraskevaidi4, Antonios Athanasiou ${ }^{5}$, Pierre PL Martin-Hirsch ${ }^{6}$, Phillip Bennett 7 , Evangelos Paraskevaidis 5

1Surgery and Cancer - West London Gynaecological Cancer Center, Imperial College - Queen Charlotte's \& Chelsea, Hammersmith Hospital, Imperial NHS Healthcare Trust, London, UK. 2Institute of Reproductive and Developmental Biology, Imperial College London, London, UK. ${ }^{3}$ Unit of Cancer Epidemiology, Belgian Cancer Centre, Scientific Institute of Public Health, Brussels, Belgium. ${ }^{4}$ Department of Chemistry, University of Ioannina, Ioannina, Greece. ${ }^{5}$ Department of Obstetrics and Gynaecology, loannina University Hospital, Ioannina, Greece. ${ }^{6}$ Gynaecological Oncology Unit, Royal Preston Hospital, Lancashire Teaching Hospital NHS Trust, Preston, UK.

${ }^{7}$ Parturition Research Group, Imperial College London, London, UK

Contact: Maria Kyrgiou, Surgery and Cancer - West London Gynaecological Cancer Center, Imperial College - Queen Charlotte's \& Chelsea, Hammersmith Hospital, Imperial NHS Healthcare Trust, Du Cane Road, London, W12 0NN, UK. m.kyrgiou@imperial.ac.uk, mkyrgiou@yahoo.com.

Editorial group: Cochrane Gynaecological, Neuro-oncology and Orphan Cancer Group.

Publication status and date: Edited (no change to conclusions), published in Issue 9, 2016.

Citation: Kyrgiou M, Mitra A, Arbyn M, Paraskevaidi M, Athanasiou A, Martin-Hirsch PPL, Bennett P, Paraskevaidis E. Fertility and early pregnancy outcomes after conservative treatment for cervical intraepithelial neoplasia. Cochrane Database of Systematic Reviews 2015, Issue 9. Art. No.: CD008478. DOI: 10.1002/14651858.CD008478.pub2.

Copyright @ 2016 The Cochrane Collaboration. Published by John Wiley \& Sons, Ltd.

\section{A B S T R A C T}

\section{Background}

Cervical intra-epithelial neoplasia (CIN) typically occurs in young women of reproductive age. Although several studies have reported the impact that cervical conservative treatment may have on obstetric outcomes, there is much less evidence for fertility and early pregnancy outcomes.

\section{Objectives}

To assess the effect of cervical treatment for CIN (excisional or ablative) on fertility and early pregnancy outcomes.

\section{Search methods}

We searched in January 2015 the following databases: the Cochrane Gynaecological Cancer Specialised Register, Cochrane Central Register of Controlled Trials (CENTRAL; The Cochrane Library, Issue 12, 2014), MEDLINE (up to November week 3, 2014) and EMBASE (up to week $52,2014)$.

\section{Selection criteria}

We included all studies reporting on fertility and early pregnancy outcomes (less than 24 weeks of gestation) in women with a history of $\mathrm{CIN}$ treatment (excisional or ablative) as compared to women that had not received treatment.

\section{Data collection and analysis}

Studies were classified according to the treatment method used and the fertility or early pregnancy endpoint. Pooled risk ratios (RR) and $95 \%$ confidence intervals $(\mathrm{Cl})$ were calculated using a random-effects model and inter-study heterogeneity was assessed with 12 . Two review authors (MK, AM) independently assessed the eligibility of retrieved papers and risk of bias. The two review authors then compared their results and any disagreements were resolved by discussion. If still unresolved, a third review author (MA) was involved until consensus was reached. 


\section{Main results}

Fifteen studies (2,223,592 participants - 25,008 treated and 2,198,584 untreated) that fulfilled the inclusion criteria for this review were identified from the literature search. The meta-analysis demonstrated that treatment for CIN did not adversely affect the chances of conception. The overall pregnancy rate was higher for treated (43\%) versus untreated women (38\%; RR $1.29,95 \% \mathrm{Cl} 1.02$ to $1.64 ; 4$ studies, 38,050 participants, very low quality), although the inter-study heterogeneity was considerable $(\mathrm{P}<0.01)$. The pregnancy rates in treated and untreated women with an intention to conceive ( $88 \%$ versus $95 \%$, RR $0.93,95 \% \mathrm{Cl} 0.80$ to $1.08 ; 2$ studies, 70 participants, very low quality) and the number of women requiring more than 12 months to conceive ( $14 \%$ versus $9 \%, \mathrm{RR} 1.45,95 \% \mathrm{Cl} 0.89$ to $2.37 ; 3$ studies, 1348 participants, very low quality) were no different. Although the total miscarriage rate (4.6\% versus $2.8 \%, \mathrm{RR} 1.04,95 \% \mathrm{Cl} 0.90$ to $1.21 ; 10$ studies, 39,504 participants, low quality) and first trimester miscarriage rate (9.8\% versus $8.4 \%, \mathrm{RR} 1.16,95 \% \mathrm{Cl} 0.80$ to $1.69,4$ studies, 1103 participants, low quality) was similar for treated and untreated women, CIN treatment was associated with an increased risk of second trimester miscarriage, (1.6\% versus $0.4 \%, \mathrm{RR} 2.60,95 \% \mathrm{Cl} 1.45$ to $4.67 ; 8$ studies, $2,182,268$ participants, low quality). The number of ectopic pregnancies ( $1.6 \%$ versus $0.8 \%$, RR $1.89,95 \% \mathrm{Cl} 1.50$ to $2.39 ; 6$ studies, 38,193 participants, low quality) and terminations (12.2\% versus $7.4 \%, \mathrm{RR} 1.71,95 \% \mathrm{Cl} 1.31$ to 2.22; 7 studies, 38,208 participants, low quality) were also higher in treated women.

The results should be interpreted with caution. The included studies were often small with heterogenous design. Most of these studies were retrospective and of low or very low quality (GRADE assessment) and were therefore prone to bias. Subgroup analyses for the individual treatment methods and comparison groups and analysis to stratify for the cone length was not possible.

\section{Authors' conclusions}

This meta-analysis suggests that treatment for CIN does not adversely affect fertility, although treatment was associated with an increased risk of miscarriage in the second trimester. These results should be interpreted with caution as the included studies were non-randomised and many were of low or very low quality and therefore at high risk of bias. Research should explore mechanisms that may explain the increase in mid-trimester miscarriage risk and stratify this impact of treatment by the length of the cone and the treatment method used.

\section{PLAIN LANGUAGE SUMMARY}

\section{Fertility and early pregnancy outcomes after treatment for cervical pre-cancer (cervical intra-epithelial neoplasia)}

\section{The issue}

Preterm birth risk is higher after local treatment for precancer of the neck of the womb (cervix), yet there are only a few research studies that have investigated the effect on fertility and early pregnancy outcomes following treatment.

\section{The aim of the review}

We aimed to assess whether treatment for this cancer - cervical intra-epithelial neoplasia (CIN) - adversely affects the chances of a successful conception and pregnancy outcomes in the first and second trimesters (less than 24 weeks of gestation).

\section{What are the main findings?}

We included all studies that assessed fertility and early pregnancy outcomes in women who had local treatment of CIN versus untreated women. We identified fifteen suitable studies.

\section{Fertility outcomes}

The results suggest that local treatment of the cervix does not adversely affect the ability to conceive; in fact the overall pregnancy rate was higher for treated women when compared to untreated women (43\% versus $38 \%$ ). There was no difference in the pregnancy rates in women that intended to conceive ( $88 \%$ treated versus $95 \%$ untreated) or in the number of women requiring more than 12 months to conceive (15\% treated versus $9 \%$ untreated).

\section{Early pregnancy outcomes}

The rates of total (less than 24 weeks of gestation) and first trimester (less than 12 weeks of gestation) miscarriage were no different. However, women after treatment had a significantly higher second trimester miscarriage rate (between 12 and 24 weeks of gestation) compared to untreated controls ( $1.6 \%$ versus $0.4 \%)$. The rates of ectopic pregnancies and terminations of pregnancy were higher for treated versus untreated women.

\section{What is the quality of the evidence?}

The results should be interpreted with caution as the included studies were small and of mixed design. Most of the studies were of low quality and retrospective (looking at information recorded previously). Investigation of the effect of different treatments techniques and of the size of the tissue removed (i.e. cone length) was not possible.

\section{What are the conclusions?}

The results suggest that treatment for CIN does not adversely affect the chances of a successful conception, although treatment is associated with an increased risk of miscarriage in the second trimester. These conclusions should be interpreted with caution as the quality of the included studies was low or very low. Future research should investigate the impact related to the extent of the treatment and the treatment method used. 


\section{SUMMARY OF FINDINGS}

Summary of findings for the main comparison. Fertility outcomes for cervical intraepithelial lesions

Fertility outcomes for cervical intraepithelial lesions

Patient or population: patients with cervical intraepithelial lesions

Setting: colposcopy clinic

Intervention: cervical treatment for $\mathrm{CIN}$ (excisional or ablative)

\begin{tabular}{|c|c|c|c|c|c|c|}
\hline \multirow[t]{3}{*}{ Outcomes } & \multicolumn{2}{|c|}{ Illustrative comparative risks $(95 \% \mathrm{CI})$} & \multirow{3}{*}{$\begin{array}{l}\text { Relative effect } \\
(95 \% \mathrm{Cl})\end{array}$} & \multirow{3}{*}{$\begin{array}{l}\text { Number of par- } \\
\text { ticipants } \\
\text { (studies) }\end{array}$} & \multirow{3}{*}{$\begin{array}{l}\text { Quality of the } \\
\text { evidence } \\
\text { (GRADE) }\end{array}$} & \multirow[t]{3}{*}{ Comments } \\
\hline & Assumed risk & Corresponding risk & & & & \\
\hline & Untreated & $\begin{array}{l}\text { Cervical treatment for } \\
\text { CIN (excisional or abla- } \\
\text { tive) }\end{array}$ & & & & \\
\hline \multirow{4}{*}{$\begin{array}{l}\text { Total pregnan- } \\
\text { cy rate }\end{array}$} & \multicolumn{2}{|c|}{ Study population } & \multirow{4}{*}{$\begin{array}{l}\text { RR } 1.29 \\
(1.02 \text { to } 1.64)\end{array}$} & \multirow{4}{*}{$\begin{array}{l}38050 \\
\text { (4 studies) }\end{array}$} & \multirow{4}{*}{$\begin{array}{l}\oplus \ominus \ominus \ominus \\
\text { very low } 1\end{array}$} & Observational studies only \\
\hline & 382 per 1000 & $\begin{array}{l}\mathbf{4 9 3} \text { per } 1000 \\
\text { (390 to } 627)\end{array}$ & & & & $\begin{array}{l}1 \text { study assessed as low quality. } \\
2 \text { studies downgraded to very low quality due }\end{array}$ \\
\hline & \multicolumn{2}{|c|}{ Control population } & & & & $\begin{array}{l}\text { to study design (high risk of publication bias) } \\
\text { and wide confidence intervals. }\end{array}$ \\
\hline & 368 per 1000 & $\begin{array}{l}\mathbf{4 7 5} \text { per } 1000 \\
\text { ( } 375 \text { to } 604)\end{array}$ & & & & $\begin{array}{l}11 \text { study upgraded to moderate quality due to } \\
\text { large study population and magnitude of effect. }\end{array}$ \\
\hline \multirow{4}{*}{$\begin{array}{l}\text { Pregnancy rate } \\
\text { in women with } \\
\text { intention to } \\
\text { conceive }\end{array}$} & \multicolumn{2}{|c|}{ Study population } & \multirow{4}{*}{$\begin{array}{l}\text { RR } 0.93 \\
(0.8 \text { to } 1.08)\end{array}$} & \multirow{4}{*}{$\begin{array}{l}70 \\
\text { (2 studies) }\end{array}$} & \multirow{4}{*}{$\begin{array}{l}\oplus \ominus \ominus \ominus \\
\text { very low } 2\end{array}$} & Observational studies only \\
\hline & 946 per 1000 & $\begin{array}{l}880 \text { per } 1000 \\
(757 \text { to } 1000)\end{array}$ & & & & $\begin{array}{l}2 \text { studies assessed as very low quality due to } \\
\text { study design (high risk of publication bias) and } \\
\text { wide confidence intervals. }\end{array}$ \\
\hline & \multicolumn{2}{|c|}{ Control population } & & & & \\
\hline & 950 per 1000 & $\begin{array}{l}\mathbf{8 8 3} \text { per } \mathbf{1 0 0 0} \\
\text { (760 to } 1000)\end{array}$ & & & & \\
\hline \multirow{2}{*}{$\begin{array}{l}\text { Conception at } \\
>12 \text { months }\end{array}$} & \multicolumn{2}{|c|}{ Study population } & \multirow{2}{*}{$\begin{array}{l}\text { RR } 1.45 \\
\text { (0.89 to } 2.37)\end{array}$} & \multirow{2}{*}{$\begin{array}{l}1348 \\
\text { (3 studies) }\end{array}$} & \multirow{2}{*}{$\begin{array}{l}\oplus \ominus \ominus \ominus \\
\text { very low } 3\end{array}$} & Observational studies only \\
\hline & 92 per 1000 & $\begin{array}{l}117 \text { per } 1000 \\
\text { (62 to } 222)\end{array}$ & & & & 2 studies assessed as low quality. \\
\hline
\end{tabular}

(62 to 222$)$ 
${ }^{*}$ The basis for the assumed risk (e.g. the median control group risk across studies) is provided in footnotes. The corresponding risk (and its $95 \%$ confidence interval) is based on the assumed risk in the comparison group and the relative effect of the intervention (and its $95 \% \mathrm{Cl}$ ).

Cl: confidence interval; CIN: cervical intraepithelial neoplasia; RR: risk ratio;

GRADE Working Group grades of evidence

High quality: Further research is very unlikely to change our confidence in the estimate of effect.

Moderate quality: Further research is likely to have an important impact on our confidence in the estimate of effect and may change the estimate.

Low quality: Further research is very likely to have an important impact on our confidence in the estimate of effect and is likely to change the estimate.

Very low quality: We are very uncertain about the estimate.

1Downgraded to 'very low' due to very high heterogeneity (12 88\%).

2Downgraded to 'very low' due to all included studies assessed to be at high risk of publication bias, cohorts being poorly representative of the entire population and poor response rate to study questionnaire.

3 Downgraded to 'very low' due to high heterogeneity (12 63\%).

\section{Summary of findings 2. Early pregnancy outcomes for cervical intraepithelial lesions}

\section{Early pregnancy outcomes for cervical intraepithelial lesions}

Patient or population: patients with cervical intraepithelial lesions

Settings: colposcopy clinics

Intervention: cervical treatment for CIN (excisional or ablative)

\begin{tabular}{|c|c|c|c|c|c|c|}
\hline \multirow[t]{3}{*}{ Outcomes } & \multicolumn{2}{|c|}{$\begin{array}{l}\text { Illustrative comparative risks }{ }^{\star}(95 \% \\
\mathrm{Cl})\end{array}$} & \multirow[t]{3}{*}{$\begin{array}{l}\text { Relative effect } \\
(95 \% \mathrm{Cl})\end{array}$} & \multirow{3}{*}{$\begin{array}{l}\text { Number of par- } \\
\text { ticipants } \\
\text { (studies) }\end{array}$} & \multirow{3}{*}{$\begin{array}{l}\text { Quality of the } \\
\text { evidence } \\
\text { (GRADE) }\end{array}$} & \multirow[t]{3}{*}{ Comments } \\
\hline & Assumed risk & $\begin{array}{l}\text { Corresponding } \\
\text { risk }\end{array}$ & & & & \\
\hline & Untreated & $\begin{array}{l}\text { Cervical treat- } \\
\text { ment for CIN (ex- } \\
\text { cisional or abla- } \\
\text { tive) }\end{array}$ & & & & \\
\hline \multirow{2}{*}{$\begin{array}{l}\text { Miscarriage } \\
\text { rates }\end{array}$} & \multicolumn{2}{|c|}{ Study population } & \multirow{2}{*}{$\begin{array}{l}\text { RR } 1.04 \\
(0.9 \text { to } 1.21)\end{array}$} & \multirow{2}{*}{$\begin{array}{l}39504 \\
\text { (10 studies) }\end{array}$} & \multirow{2}{*}{$\begin{array}{l}\oplus \oplus \ominus \ominus \\
\text { low } 1\end{array}$} & \multirow{2}{*}{$\begin{array}{l}\text { Observational studies only } \\
5 \text { studies assessed as low quality. }\end{array}$} \\
\hline & 28 per 1000 & 29 per 1000 & & & & \\
\hline
\end{tabular}


(25 to 34$)$

Control population

109 per $1000 \quad 113$ per 1000

(98 to 132

3 studies downgraded to very low quality due to study design (high risk of publication bias) and wide confidence intervals.

1 study upgraded to moderate quality due to large study population and magnitude of effect.

$1^{\text {study }}$ upgraded to moderate quality due to prospective follow up of large study population and magnitude of effect.

\begin{tabular}{lll}
\hline $\begin{array}{l}\text { 1st trimester } \\
\text { miscarriage } \\
\text { rates }\end{array}$ & \multicolumn{2}{l}{ Study population } \\
\cline { 2 - 3 } & $\mathbf{8 4}$ per 1000 & $\begin{array}{l}\mathbf{9 7} \text { per } 1000 \\
\text { (67 to 142) }\end{array}$ \\
\hline & & \\
&
\end{tabular}

RR 1.16

(0.8 to 1.69$)$

1103

(4 studies)

$\oplus \oplus \odot \ominus$

low 2

Observational studies only

3 studies assessed as low quality.

1 study downgraded to very low quality due to study design (high risk of publication bias) and wide confidence intervals.

Control population

83 per $1000 \quad 96$ per 1000

(66 to 140$)$

\begin{tabular}{lll}
\hline $\begin{array}{l}\text { 2nd trimester } \\
\text { miscarriage }\end{array}$ & \multicolumn{2}{l}{ Study population } \\
\cline { 2 - 3 } rates & $\mathbf{4}$ per 1000 & $\begin{array}{l}\mathbf{1 0} \text { per } 1000 \\
(6 \text { to } 18)\end{array}$
\end{tabular}

RR 2.6

(1.45 to 4.67$)$

2182268

(8 studies)

\section{$\oplus \oplus \ominus \ominus$}

low 3

(6 to 18$)$

Control population

11 per $1000 \quad 29$ per 1000

(16 to 51)

\begin{tabular}{lll}
\hline $\begin{array}{l}\text { Ectopic preg- } \\
\text { nancy }\end{array}$ & \multicolumn{2}{l}{ Study population } \\
\cline { 2 - 3 } & $\mathbf{8}$ per 1000 & $\begin{array}{l}\mathbf{1 4} \text { per } 1000 \\
(11 \text { to } 18)\end{array}$
\end{tabular}

RR 1.89

(1.5 to 2.39 )

38193

(6 studies)

$\oplus \oplus \ominus \ominus$

low2

Control population

13 per $1000 \quad 25$ per 1000

(19 to 31)

TOP rates

\begin{tabular}{l} 
Study population \\
\hline 74 per $1000 \quad 127$ per 1000
\end{tabular}

$\begin{array}{lll}\text { RR 1.71 } & 38208 & \oplus \oplus \ominus \ominus \\ \text { (1.31 to 2.22) } & \text { (7 studies) } & \text { low }^{\mathbf{3}}\end{array}$

RR 1.71 38208

(7 studies)

$\oplus \oplus \ominus \ominus$

low3

(4) 1000 p 127 per 1000




\section{Control population}

*The basis for the assumed risk (e.g. the median control group risk across studies) is provided in footnotes. The corresponding risk (and its $95 \%$ confidence interval) is

based on the assumed risk in the comparison group and the relative effect of the intervention (and its $95 \% \mathrm{Cl}$ ).

CI: Confidence interval; CIN: cervical intraepithelial neoplasia; RR: Risk ratio; TOP: termination of pregnancy

GRADE Working Group grades of evidence

High quality: Further research is very unlikely to change our confidence in the estimate of effect.

Moderate quality: Further research is likely to have an important impact on our confidence in the estimate of effect and may change the estimate.

Low quality: Further research is very likely to have an important impact on our confidence in the estimate of effect and is likely to change the estimate.

Very low quality: We are very uncertain about the estimate.

1Included three very low quality studies being poorly representative of the intended study population with wide confidence intervals and poor response rates to study questionnaires. Due to the small cohorts and good quality of the remaining included observational studies, with a large cumulative study population, however, the authors concluded that this was unlikely to significantly bias the results. In combination with the low overall heterogeneity of the analysis ( $129 \%$ ) the quality of evidence was maintained as low.

2Included one very low quality study being poorly representative of the intended study population with wide confidence intervals, however due to the small cohort, the authors concluded this was unlikely to significantly bias results. In combination with the low overall heterogeneity of the analysis ( $120 \%)$ the quality of evidence was maintained as low. 3 Included two very low quality studies being poorly representative of the intended study population with wide confidence intervals and poor response rates to study questionnaires, however due to the small cohorts and good quality of the remaining included observational studies, with a large cumulative study population the authors concluded that this was unlikely to significantly bias the results. Heterogeneity was intermediate, however the authors concluded this was unlikely to significantly bias results, therefore quality of evidence was maintained as low. 


\section{B A C K G R O U N D}

\section{Description of the condition}

Cervical cancer remains the commonest gynaecological malignancy worldwide. Over half a million new cases are diagnosed each year around the world, with the vast majority occurring in developing countries, where a woman's risk of developing cervical cancer by age 74 is $1.6 \%$, compared to $0.9 \%$ in developed countries (Ferlay 2013).

The introduction of cervical screening programmes over the last twenty years has resulted in a profound decrease in the incidence and mortality from cervical cancer through early identification and treatment of screen-detected pre-invasive lesions of the cervix, known as cervical intraepithelial neoplasia (CIN; Arbyn 2009; Quinn 1999). CIN lesions are pre-cancerous abnormalities in the cells of the cervix (neck of the womb); if left untreated, cervical cancer may develop. These lesions are asymptomatic and interventions to treat them in young women are usually offered only in highgrade disease (CIN grade 2 or 3, also known as HSIL - highgrade squamous intra-epithelial lesions; NHS Cervical Screening Programme 2010). This is because cervical treatment has been correlated to adverse obstetric sequelae (Kyrgiou 2006), while many of the low-grade lesions (also known as LSIL - low-grade squamous intra-epithelial lesions) resolve spontaneously in young individuals (NHS Cervical Screening Programme 2010).

The average age of a woman diagnosed and treated for CIN is between 25 and 30 years of age, although it may occur in women considerably younger (NHS Cervical Screening Programme 2012). As the pre-cancerous lesions typically occur in young women of reproductive age, the impact of their treatment on the outcomes of subsequent pregnancies has been an area of active research for the past decade. Whilst it is paramount that effective treatment is undertaken, it is also important that this treatment has minimal adverse effects on future fertility and pregnancy outcomes for this young female population.

\section{Description of the intervention}

Cold knife conisation (CKC), laser ablation (LA), laser conisation (LC), cryotherapy (CT), cold coagulation (CC), radical diathermy (RD), large loop excision of the transformation zone (LLETZ, also known as loop electrosurgical excisional procedure (LEEP)) and needle excision of the transformation zone (NETZ, also know as straight wire excision of the transformation zone (SWETZ); Kitchener 1995; Prendiville 1989) are all conservative local methods of treatment for CIN, which attempt to remove or destroy the transformation zone (TZ) of the cervix (the transition area from squamous to columnar epithelium in which the abnormal cells develop). These techniques use different surgical instruments (i.e. knife, laser, loop or straight wire, coagulator probe) and energy sources (i.e. laser, diathermy, coagulation) to excise or ablate a cone-shaped part of the cervix that contains the pre-cancerous cells.

The characteristics of these techniques are well described. LLETZ, LC and ablation are usually performed under local anaesthesia in an outpatient setting, while $\mathrm{CKC}$ requires general anaesthesia and hospitalisation. Theoretically, the excisional techniques (CKC, LC, LLETZ) are superior over the destructive (LA, CC, CT), as they allow a comprehensive histological evaluation of the removed tissue and the whole $\mathrm{TZ}$, with precise evaluation of excision margins. Ablative techniques destroy the TZ epithelium; they preclude histological evaluation and demand accurate pre-treatment biopsy at a separate visit. LLETZ is the most favoured technique, by combining all the advantages of the excisional techniques mentioned above together with a relatively shorter duration, low cost, good compliance, simplicity and easier learning curve for practitioners (Kitchener 1995; Prendiville 1989).

A recent Cochrane review reported that all the treatment techniques have low rates of surgical morbidity and all with the exception of CT have similar rates of pre-cancerous recurrence (Martin-Hirsch 2013; Nuovo 2000) and post-treatment invasive disease (Chew 1999; Paraskevaidis 1991; Soutter 1997).

\section{How the intervention might work}

Several meta-analyses (Arbyn 2008; Kyrgiou 2006) and large retrospective linkage studies (Albrechtsen 2008; Noehr 2009) have previously reported that women with a history of an excisional technique (CKC, LLETZ and LC) have an increased risk of preterm birth (less than 24 weeks of gestation), low-birth weight (less than 2,500 g), premature rupture of the membranes and perinatal mortality in a subsequent pregnancy. It is, however, plausible that the disease itself (CIN) and other confounders (such as smoking, occult infections etc.) may contribute to that increased risk (Bruinsma 2007; Castanon 2012; Kyrgiou 2012).

Although the impact that local treatment of the cervix has on the obstetric sequelae has been extensively described, its effect on the ability to conceive and early pregnancy outcomes has been relatively under-reported (Hammond 1990; Paraskevaidis 2007). Cervical treatment excises or ablates part of the endocervical canal and, as a result, the mucus-secreting glands, which produce secretions facilitating sperm penetration and conception. This has been suggested to adversely affect the chances of a successful conception (Kennedy 1993; Spracklen 2013; Suarez 2006). The loss of the normal functional cervical structure and the healing process in the regenerated crater after excision may also induce severe stenosis of the cervical os that may further inhibit the sperm penetration and conception (Luesley 1985; Suarez 2006).

The published evidence assessing the impact of cervical treatment fertility are somewhat inconsistent. Two small case-series (Bigrigg 1994; Weber 1979) reported that cervical treatment did not prolong the time required to conceive. A large retrospective populationbased cohort from Finland that included more than 35,000 women and a follow-up of over 250,000 women-years reported no negative effect from treatment. Treated women actually had more pregnancies and children when compared to the reference untreated population, although data for the pregnancy rates in those with the intention to conceive was not reported (Kalliala 2012). However, this study was followed by another large cohort from the USA that resulted in contradictory results. Women who were previously treated took longer to conceive than untreated women without the disease, or women who attended colposcopy but were not treated (time to conception more than 12 months $16.4 \%$ versus $8.4 \%$, adjusted odds ratio (OR) $2.09,95 \% \mathrm{Cl} 1.26$ to 3.46) (Spracklen 2013).

A systematic review that focused mainly on obstetric outcomes after cervical treatment previously reported on studies assessing the impact of treatment on fertility (Kyrgiou 2006). A meta-analysis 
on fertility outcomes was not possible due to the limited number of published reports at the time.

It has also been suggested that cervical treatment may adversely impact on early pregnancy outcomes. Although first-trimester miscarriages are usually a result of fetal malformation and abnormal karyotype (Phillipp 2003), mid-trimester losses (second trimester miscarriages) share common aetiopathogenic pathways with preterm birth related to cervical incompetence, inflammation and damage of the host's defence mechanisms (Kyrgiou 2015).

\section{Why it is important to do this review}

Authors who have assessed fertility outcomes have reached contradictory conclusions based on data from rather small populations. There are no randomised controlled trials (RCTs) that compare fertility and early pregnancy outcomes in treated versus untreated women with CIN. Due to the pre-malignant nature of the condition that is being treated, it is unlikely that one will ever be conducted. The best level of evidence may therefore be drawn from a systematic review and meta-analysis of cohort studies.

The impact that the treatment may have on conception and childbearing causes anxiety and psychological morbidity to many young women requiring local treatment of the cervix. Although the impact that cervical treatment may have on obstetric outcomes has been the subject of several large studies (Castanon 2014b; Jakobsson 2007) and meta-analyses (Arbyn 2008; Bruinsma 2011; Kyrgiou 2006), the existing evidence on the early pregnancy and fertility outcomes is limited, often contradictory and poorly documented.

A systematic review and meta-analysis focusing on fertility and early pregnancy outcomes in women who have had a local treatment of the cervix as compared to those who have not was clearly overdue. This review critically appraises the existing literature and quantifies the impact that these interventions may have on women's reproductive health. This data can help clinicians' decision making and inform patients' choice. It further allows the identification of a group at high-risk of mid-trimester loss. Although the data analysed only relies on retrospective cohorts that may be prone to bias, the results provide a comprehensive overview of the published literature.

\section{O B JE C T I VES}

To assess the effect of cervical treatment for CIN (excisional or ablative) on fertility and early pregnancy outcomes.

\section{METHODS}

\section{Criteria for considering studies for this review}

\section{Types of studies}

We included all studies reporting on fertility and early pregnancy outcomes (less than 24 weeks of gestation) in women with a history of CIN treatment as compared to women who did not received treatment.

Studies were included irrespective of the type of untreated reference population. The comparison group could include: a) untreated women from the general population matched or not for known risk factors and possible confounders; b) internal controls with self-matching pregnancies for the same women before treatment; $c$ ) women with CIN that attended colposcopy but did not receive treatment. Given the non-randomised nature of the included studies, the choice of comparison group may impact on the risk estimate for each reported outcome and may introduce bias by over-estimating the effect of treatment that may be partly attributed to other confounders (Kyrgiou 2012).

We excluded studies that did not include an untreated reference population. Studies that compared outcomes for treatments performed during pregnancy were also excluded.

\section{Types of participants}

All women of reproductive potential (fertility outcomes) and all women that had a pregnancy (early pregnancy outcomes) with or without a previous conservative local treatment of the cervix for $\mathrm{CIN}$ were eligible for inclusion. Women were included irrespective of the grade of the lesion for both squamous and glandular intraepithelial neoplasia.

\section{Types of interventions}

The interventions included any type of conservative local method of treatment, either excisional (CKC, LLETZ/LEEP, LC, NETZ/SWETZ) or ablative (LA, CT, CC, RD). In studies that reported on the impact of several different treatment techniques, as compared to untreated controls, we extracted the outcomes according to specific treatment method, where possible. If the outcomes in an individual study were not reported separately for each technique, we analysed the intervention under broader terms, i.e. excisional treatment not otherwise specified (NOS), ablative treatment NOS and treatment NOS. The detailed information on the exact treatment technique is not infrequently unavailable in national registries.

\section{Types of outcome measures}

\section{Primary outcomes}

Total pregnancy rates (fertility outcome).

\section{Secondary outcomes}

- Fertility outcomes:

- Pregnancy rates in women with an intention to conceive in an unspecified period.

- Conception rates within a given period: 0 to 3 months $(\mathrm{m}), 0$ to $6 \mathrm{~m}, 0$ to $9 \mathrm{~m}, 0$ to $12 \mathrm{~m}, 0$ to $24 \mathrm{~m},>12 \mathrm{~m},>36 \mathrm{~m}$.

- Early pregnancy outcomes (less than 24 weeks of gestation):

- Total miscarriage rates (less than 24 weeks of gestation).

- First trimester miscarriage rates (less than 12 weeks of gestation).

- Second trimester miscarriage rates (between 12 and 24 weeks of gestation).

- Ectopic pregnancy rates.

- Molar (abnormal development of foetus and placenta) pregnancy rates.

- Termination of pregnancy rates.

\section{Search methods for identification of studies}

We sought papers in all languages and carried out translations if necessary. The literature searches started in 1948 and included references published up to November 2014. 


\section{Electronic searches}

See the Cochrane Gynaecological Cancer Group methods used in reviews.

We searched the following electronic databases in January 2015:

- The Cochrane Gynaecological Cancer Specialised Register.

- Cochrane Central Register of Controlled Trials (CENTRAL; The Cochrane Library, Issue 12, 2014).

- MEDLINE (1948 to November week 3, 2014).

- EMBASE (1980 to week 52, 2014).

The MEDLINE search strategy based on terms related to the review topic is presented in Appendix 1. We used the 'related articles' feature in MEDLINE to retrieve additional references. For databases other than MEDLINE, we adapted the search strategy accordingly. The full search strategies for EMBASE and CENTRAL are attached in Appendix 2 and Appendix 3.

\section{Searching other resources}

We searched metaregister, Physicians Data Query, www.controlledtrials.com/rct, www.clinicaltrials.gov and www.cancer.gov/ clinicaltrials for ongoing studies and contacted the main investigators of any relevant ongoing trials for further information.

We searched conference proceedings and abstracts through ZETOC (http://zetoc.mimas.ac.uk) and WorldCat Dissertations. We also searched reports of conferences within the following sources:

- Annual Meeting of the British Society of Colposcopy and Cervical Pathology.

- Annual Meeting of the International Federation of Cervical Pathology and Colposcopy.

- Annual Meeting of European Federation of Colposcopy.

- Annual Meeding of the American Society of Colposcopy and Cervical Pathology.

We checked the citation lists of included studies and contacted experts in the field, including directors of UK cancer and colposcopy registries, to identify further reports of studies.

We included both published and unpublished studies that met the inclusion criteria for the review.

\section{Data collection and analysis}

\section{Selection of studies}

We downloaded all titles and abstracts retrieved by electronic searching into a database using the reference management software, EndNote. We removed duplicates and two review authors (MK, AM) independently examined the remaining references. Titles and abstracts retrieved from other sources were also added to the EndNote database. Those studies which clearly did not meet the inclusion criteria were excluded and copies of the full text of potentially relevant references were obtained. Two review authors (MK, AM) independently assessed the eligibility of retrieved papers. The two review authors then compared their results and any disagreements were resolved by discussion. If still unresolved, a third review author (MA) was involved until consensus was reached. Reasons for exclusion were documented.

\section{Data extraction and management}

We classified the studies according to treatment modality (i.e. CKC, LC, LLETZ, LA etc) and in groups of excisional or ablative techniques.

We retrieved from each study the number of events in treated and untreated women for each outcome of interest (fertility and early pregnancy outcomes). We did not need to contact authors of the included studies, as all the required data were provided in the original reports.

We distinguished the different untreated reference populations across studies: a) matched to the treated group for known risk factors, b) self-matching/internal controls, i.e. the same women before versus after treatment, c) women who attended colposcopy with or without biopsy who did not undergo treatment. The matching criteria applied for the selection of an untreated group of women were also recorded (i.e. age, parity, smoking, socioeconomic status, etc.).

For included studies, the following data were extracted:

- Author, year of publication, journal and language.

- Country.

- Setting in which the study was conducted.

- Inclusion and exclusion criteria.

- Study design, methodology.

- Study population:

- Total number enrolled and number included in each group.

- Patient characteristics.

- Age.

- Grade of CIN.

- Parity.

- Single/multiple pregnancy.

- Smoking history.

- Socioeconomic status.

- Cone size/length.

- Control for confounding factors.

- Intervention details:

- Type of procedure used (excisional or ablative)

- Pprocedure used (excisional: CKC, LLETZ/LEEP, LC, NETZ/ SWETZ; ablative: LA, RD, CC, CT).

- Details of the untreated group: (a) general population matched to the treated group for known risk factors, b) self-matching/ internal controls that compare outcomes of the same women before and after CIN treatment, c) women who attended colposcopy with or without biopsy who did not undergo treatment.

- Risk of bias (Assessment of risk of bias in included studies).

- Outcomes reported in each study:

- Primary outcomes:

- Total pregnancy rates in treated versus untreated women.

- Secondary outcomes:

- Fertility outcomes: pregnancy rates in women with an intention to conceive; conception rates within a given period: 0 to 3 months (m), 0 to $6 \mathrm{~m}, 0$ to $9 \mathrm{~m}, 0$ to $12 \mathrm{~m}, 0$ to $24 \mathrm{~m}$, more than $12 \mathrm{~m}$, more than $36 \mathrm{~m}$.

- Early pregnancy outcomes (less than 24 weeks of gestation): total miscarriage rates; first trimester 
miscarriage rates; second trimester miscarriage rates; ectopic pregnancy rates; molar pregnancy rates; termination of pregnancy rates.

- Additional outcome data:

- Outcome definition.

- Number of participants allocated to each group.

- For each outcome of interest: number of observed events and missing participants.

- For dichotomous outcomes of interest: number of observed events in each group (treated and untreated) and missing participants.

Two review authors (MK, AM) independently extracted data. The review authors resolved differences by discussion or by appeal to a third review author (MA), if necessary.

\section{Assessment of risk of bias in included studies}

To assess the risk of bias in included RCTs, we planned to use the Cochrane Collaboration's tool, comprising assessments of the following study characteristics: sequence generation; allocation concealment; blinding (of participants, healthcare providers and outcome assessors); incomplete outcome data; selective reporting of outcomes; other possible sources of bias (Higgins 2011).

As RCTs comparing women with CIN to non-treated are not feasible or ethical due to the pre-malignant nature of the condition, we anticipated that published evidence might rely only on observational cohort studies. As the comparison groups (treated for CIN with a particular procedure versus non-treated) are nonrandomised, effects and effect sizes cannot be attributed with certainty to the treatment alone. The differences in the size of the treatment effect across studies may be partly explained by the choice of control population, because women with CIN may have demographic and behavioural characteristics or even background immunological imbalances that place them at higher baseline risk of adverse reproductive outcomes.

It should also be noted that all eligible comparison groups have advantages and limitations. A recent meta-analysis showed that the use of historical external controls might produce inherent biases that could inflate the contribution of cervical treatment to adverse outcomes, even if the authors control for possible confounders (such as age, parity, smoking etc; Bruinsma 2011). The use of internal controls (pregnancies in the index woman before treatment) is an attractive alternative approach, but even this might be inadequate for confounders that are liable to change with time. Women with mild precancerous lesions that do not warrant excision treatment probably provide the best, although still imperfect, comparator. In contrast, those with high-grade disease who neglect treatment advice aimed at preventing cancer may have high risk for confounders related to low socioeconomic class that may influence fertility or pregnancy outcomes.

For non-randomised studies (NRS), the risk of bias was assessed using the Newcastle-Ottawa score (Wells 2010), according to the MOOSE checklist (Stroup 2000). This scoring system was developed for assessment of non-randomised cohort studies, based on 3 areas: a) cohort selection, b) comparability and c) assessment of outcomes, to give a maximum score of 9 (highest quality). The questions for the cohort selection assessed whether the exposed and non-exposed cohorts were representative and appropriately selected, how the exposure had been ascertained and whether there was evidence that the outcome of interest was not present at the start of the study. The comparability section assessed whether the design or analysis ensured comparability of the exposed and un-exposed cohorts. Finally the outcome section assessed how the outcome was recorded and whether there was adequate follow-up.

We used the GRADE (Grading of Recommendations, Assessment, Development and Evaluation) (GRADE Working Group 2004) approach to assess the quality of evidence provided by the included studies. We used GRADEpro (GRADE profiler) software to generate 'Summary of findings' tables to include an assessment of all outcomes analysed. All studies were observational, thus were assessed as low quality. We downgraded four studies to very low quality due to risk of publication bias and wide confidence intervals. We upgraded three studies due to large cohort size, plus prospective study design in one case.

\section{Measures of treatment effect}

We calculated the risk ratio (RR) and 95\% confidence intervals $(\mathrm{CI})$ for each reported outcome in the treated versus untreated women for dichotomous outcomes. We used a random-effects model to establish the RRs (Dersimonian 1986). In studies with zero events in the treated or control group, or both we added 0.5 in each cell of the contingency table to allow calculation of RRs.

\section{Dealing with missing data}

We had intended to contact authors to obtain additional data when only event rates were reported and the absolute number of adverse obstetrical outcomes and total group sizes could not be computed with sufficient precision from the data provided in the original report. However, all the relevant data were contained in the original reports.

\section{Assessment of heterogeneity}

We assessed inter-study heterogeneity with the Cochran $\mathrm{Q}$ test (Cochran 1954), by visual inspection of forest plots, by estimation of the percentage of heterogeneity between trials which cannot be ascribed to sampling variation ( 12 statistic; Higgins 2003) and by a formal statistical test of the significance of the heterogeneity (Deeks 2001). If there was evidence of substantial heterogeneity, the possible reasons for this were investigated and reported.

\section{Assessment of reporting biases}

We planned to assess small study effects, i.e. whether RRs are greater in studies with fewer participants, by visual exploration of asymmetry in funnel plots and by two formal statistical tests: the rank correlation test (Begg 1994) and the asymmetry regression test (Egger 1997). Given the low number of studies included in each of the meta-analyses, however, reporting bias could not be formally assessed.

\section{Data synthesis}

We pooled the results of the studies in meta-analyses. For dichotomous outcomes, we calculated RR and $95 \% \mathrm{Cl}$.

In studies with multiple treatment groups, we proportionally divided the 'shared' comparison group into the number of treatment groups; we treated comparisons between each treatment group and the split comparison group as independent comparisons. 
We used random-effects models with inverse variance weighting for all meta-analyses (Dersimonian 1986).

If data were not of suitable quality for meta-analysis, we reported the results as a narrative in the text of the review.

\section{Subgroup analysis and investigation of heterogeneity}

The protocol of this Cochrane review foresaw to assess the impact of co-variates on the effect size by performing subgroup meta-analyses and meta-regression. Moreover, we were planning to explore the influence of the following study characteristics: calendar period, continent, study type (prospective versus retrospective), type of comparison group and cone size.

Due to the limited number of studies for each outcome, subgroup analyses for the different comparison groups was not possible. Furthemore, subgroup analyses for the cone size/length or the interval from treatment to conception were also not feasible, as these data were not available in the included studies.

We separated the effects of treatment by broad treatment types (excisional NOS, ablative NOS or treatment NOS) and, if possible, by the exact treatment procedure, and compared them to untreated controls.

\section{Sensitivity analysis}

Meta-analyses were repeated by restriction to studies where comparability of treated and non-treated groups was assured.

\section{RESULTS}

\section{Description of studies}

The characteristics of the included and excluded studies and the outcomes examined are described in the Characteristics of included studies and Characteristics of excluded studies.

\section{Results of the search}

We retrieved 2027 citations from the literature search. Of those, 1816 were excluded based on the title and abstract; 211 were retrieved in full text for evaluation. We identified 15 studies that fulfilled the inclusion criteria and 196 were excluded. No unpublished studies could be identified. The details, including reasons for exclusion, are present in the PRISMA flowchart (Moher 2009; Figure 1).

\section{Figure 1. PRISMA flowchart}

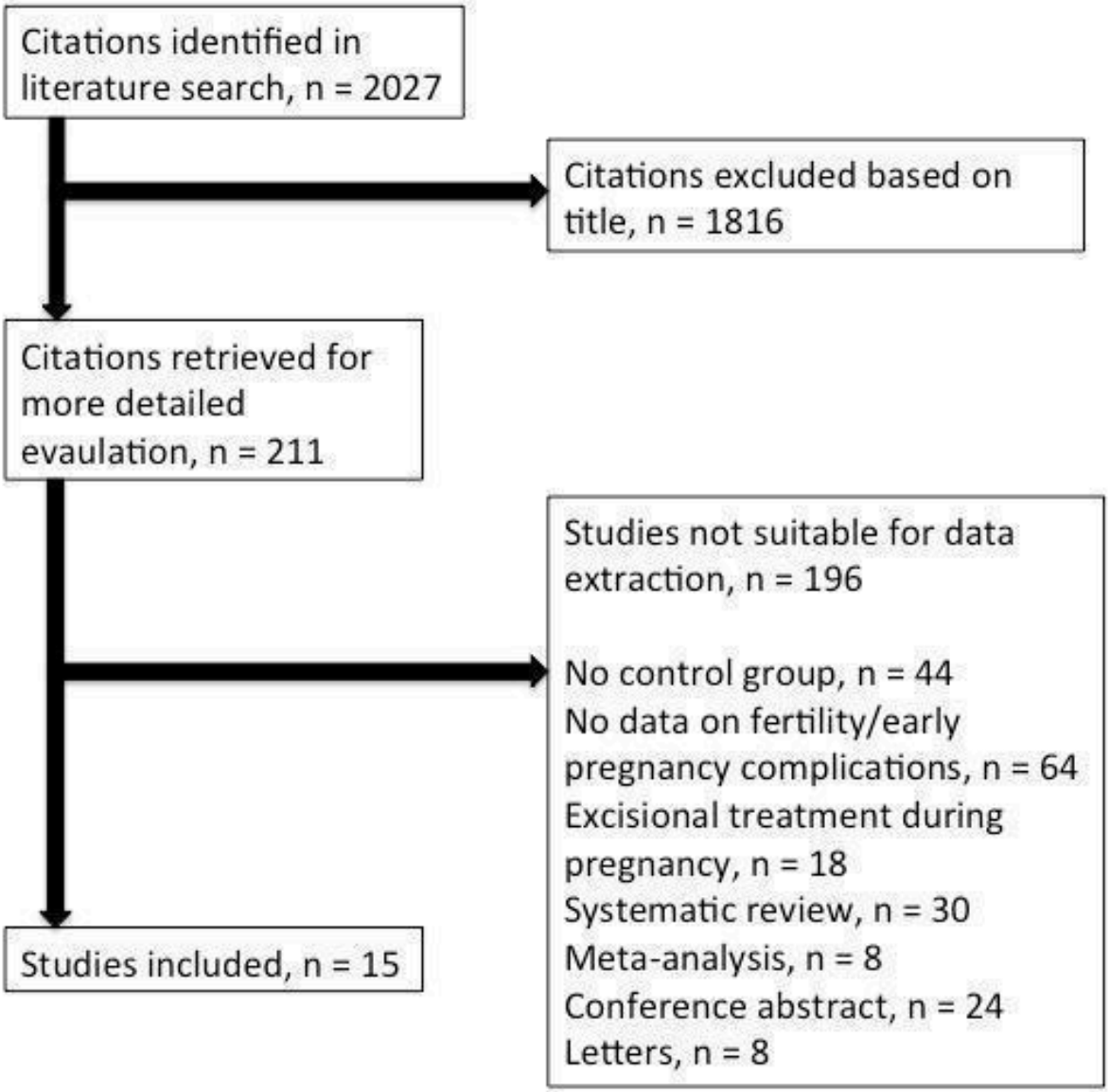




\section{Included studies}

Fifteen studies assessed fertility and early pregnancy outcomes in treated and non-treated women and were included in the analyses. All, apart from one (Frega 2013), were retrospective cohort and case-control studies. There were no RCTs.

Three studies examined the impact of CKC on the studied outcomes (Buller 1982; Larsson 1982; Weber 1979), six the impact of LLETZ (Bigrigg 1994; Blomfield 1993; Cruickshank 1995; Frega 2013; Tan 2004; Turlington 1996), one of LC (Sagot 1995) and the remaining five examined multiple treatment techniques (Albrechtsen 2008; Kallialla 2012; Sjoborg 2007; Spitzer 1995; Spracklen 2013).

Some studies used as the comparison group untreated women from the general population, matched for known risk factors leading to adverse reproductive outcomes (Bigrigg 1994; Blomfield 1993; Cruickshank 1995; Frega 2013; Tan 2004; Weber 1979). Some studies included women attending colposcopy with or without biopsy, who did not have treatment (Spracklen 2013; Turlington 1996), others used internal controls (the outcomes of the same women before treatment; Buller 1982; Larsson 1982; Sagot 1995; Spitzer 1995; Weber 1979) whilst some performed a logistic regression to control for possible confounders (Albrechtsen 2008; Kallialla 2012; Sjoborg 2007; Spracklen 2013). Specifically, Spracklen 2013 included two comparison groups: women from the general population and women who attended colposcopy but were not treated.

The data were retrieved from hospital records, questionnaires and national registries. The number of participants in the treated and untreated groups ranged from 21 to 15,108 and 20 to $2,164,006$, respectively (Characteristics of included studies).

\section{Excluded studies}

One hundred and ninety-six studies were deemed unsuitable for inclusion. Of those, 44 did not include an untreated group, 64 did not include data on the fertility and early pregnancy complications, 18 described data for excisions performed during pregnancy, 30 were systematic reviews, eight were meta-analyses and eight were letters with no relevant data (Characteristics of excluded studies). Twenty four conference abstracts were identified and classified as 'studies awaiting classification' due to a lack of sufficient detail enabling a decision regarding inclusion. We handsearched the reference lists of the identified systematic reviews and meta-analyses that assessed fertility or early pregnancy outcomes following CIN treatment (Kyrgiou 2006). No additional studies were identified.

\section{Risk of bias in included studies}

The included studies were not randomised; they described retrospective cohorts of low quality and were therefore at high risk of underlying bias. The majority of them were small (less than 500 cases and controls). The included studies varied with regard to design, the data source, the study and comparison populations, the reported outcomes, the length of follow-up and the matching for possible confounders.

The comparison group used and the adjustment for possible risk factors are important measures of study quality and risk of bias. From the 10 studies that used external comparators, four used logistic regression to adjust for possible confounders, as described previously (Albrechtsen 2008; Kallialla 2012; Sjoborg 2007; Spracklen 2013). From the ones that matched for known confounders, two matched for two factors (Bigrigg 1994; Weber 1979), and four matched for more than three factors (Blomfield 1993; Cruickshank 1995; Frega 2013; Sjoborg 2007). Four studies used internal controls (Buller 1982; Larsson 1982; Sagot 1995; Spitzer 1995) and two of those matched for further risk factors (Larsson 1982; Spitzer 1995). The comparison of treated women to women who attended colposcopy but were not treated is likely to offer the best control for possible confounders; only two small studies included such a comparison (Spracklen 2013; Turlington 1996).

The two largest studies were population-based studies from Finland (Kallialla 2012) and Norway (Albrechtsen 2008) and provided the best quality data on total pregnancy rates and second trimester miscarriages, respectively. Another large populationbased study from the USA (Spracklen 2013) reported on a clinically informative outcome: the conception rate within a given period. This study included two comparison groups: one of untreated women and another of women who attended colposcopy but did not receive treatment. Although results from telephone interviews are often at high risk of recall bias, this is an informative study of good quality, reporting on the most relevant fertility outcome. The study from Italy was prospective, describing a relatively large cohort, but only reported on the total miscarriage rate, which is a less useful clinical outcome (Frega 2013). Previous smaller studies were less informative and of lower quality.

All included studies scored at least seven points on the NewcastleOttawa Scale. More specifically, six studies scored nine points (Albrechtsen 2008; Blomfield 1993; Frega 2013; Kallialla 2012; Larsson 1982; Tan 2004), three studies scored eight points (Sjoborg 2007; Spracklen 2013; Weber 1979) and the remaining six scored seven points (Buller 1982; Bigrigg 1994; Cruickshank 1995; Sagot 1995; Sjoborg 2007; Turlington 1996). The exposed group was truly or somewhat representative of the average women in the community in all studies. All non-exposed cohorts were drawn from the same community or included the same women before and after treatment. The exposure was ascertained by the hospital or registry records in the majority of the studies; in only one study this was done by computer-assisted structured interviews (Spracklen 2013). All studies attempted to control for possible imbalances amongst the compared population (comparability of the groups) by matching (Bigrigg 1994; Blomfield 1993; Cruickshank 1995; Frega 2013; Tan 2004; Weber 1979), regression analysis for known risk factors (confounders; Albrechtsen 2008; Kallialla 2012; Sjoborg 2007; Spracklen 2013), self-matching (Buller 1982; Larsson 1982; Sagot 1995; Spitzer 1995; Weber 1979) or using as comparators women who attended colposcopy but did not receive treatment (Spracklen 2013; Turlington 1996). The majority used record linkage for the assessment of the outcome, although five relied on self-reporting (Bigrigg 1994; Cruickshank 1995; Spitzer 1995; Spracklen 2013; Turlington 1996). All studies had long follow-up and demonstrated that the outcome was not present at the start of the study. In six studies, most subjects were accounted for (adequacy of follow-up; Albrechtsen 2008; Blomfield 1993; Frega 2013; Kallialla 2012; Larsson 1982; Weber 1979), while in eight a substantial proportion of the subjects $(>20 \%)$ were not accounted for, because these women did not respond to the questionnaire, did not give consent or were lost to follow-up and data could not be retrieved (Buller 1982; Bigrigg 1994; Cruickshank 1995; Sagot 1995; 
Sjoborg 2007; Spitzer 1995; Tan 2004; Turlington 1996). A more detailed assessment is included in Appendix 4.

A description of the quality of the evidence is provided based on the GRADE assessment for the fertility (Summary of findings for the main comparison) and early pregnancy outcomes (Summary of findings 2). As RCTs allocating women with CIN to non-treatment cannot be performed due to the pre-malignant nature of the condition, the only available evidence relies on observational cohort studies. The included retrospective cohort studies are described as being of low or very low quality, as these are nonrandomised (Quality of the evidence). We used unadjusted data for the analyses. As most of the included studies were at low risk of bias and the adjusted analysis for the two largest studies reported similar results to the unadjusted one (Albrechtsen 2008; Kallialla 2012), it is unlikely that this has introduced bias.

\section{Incomplete outcome data}

All studies except for Frega 2013 described retrospective cohorts. The studies that used hospital records or national registries as their information source did not provide information on missing patient or outcome data and their risk of attrition bias was assessed to be low (Albrechtsen 2008; Blomfield 1993; Kallialla 2012; Larsson 1982). Frega 2013 reported that 18 women (3.7\%) were lost to follow-up and the risk of incomplete data was therefore low. In one study that used data drawn from interviews, there was no documentation of the response rate and the risk of attrition bias was determined to be unclear (Weber 1979). Studies that used questionnaires or required retrospective consent from patients for data use had largely high proportions of non-responders and their risk of incomplete outcome data was deemed to be high (Bigrigg 1994; Buller 1982; Cruickshank 1995; Sagot 1995; Sjoborg 2007; Spitzer 1995; Spracklen 2013; Tan 2004; Turlington 1996).

\section{Selective reporting}

The vast majority of the studies were retrospective cohort. Only Frega 2013 followed up patients prospectively. None of the studies had previously published a protocol and therefore the assessment of possible reporting bias in each one of the individual studies was difficult. There was no reason to suspect any selective reporting of patients. However, the collected data were derived from registries, clinic data sets, telephone contacts and mailed questionnaires and this may present risks of selective reporting by patients or researchers.

\section{Other potential sources of bias}

There were no other obvious sources of bias in most of the published reports (Blomfield 1993; Buller 1982; Frega 2013; Kallialla 2012; Larsson 1982; Sagot 1995; Sjoborg 2007; Tan 2004). However, some retrospective cohorts reporting on fertility outcomes collected data through questionnaires and interviews. More specifically, six studies sourced information from patient telephone interviews or mail questionnaires (Bigrigg 1994; Cruickshank 1995; Spitzer 1995; Spracklen 2013; Turlington 1996; Weber 1979). This study design may not provide a good crosssection of patients and may be subject to a greater degree of recall bias (Bigrigg 1994; Cruickshank 1995; Spitzer 1995; Spracklen 2013; Turlington 1996; Weber 1979) and misclassification bias (Albrechtsen 2008; Bigrigg 1994; Cruickshank 1995; Spitzer 1995; Spracklen 2013; Turlington 1996; Weber 1979) when compared to studies obtaining information from hospital records (Blomfield 1993; Buller 1982; Larsson 1982; Sagot 1995; Tan 2004) or national registries (Albrechtsen 2008; Kallialla 2012; Sjoborg 2007).

\section{Effects of interventions}

See: Summary of findings for the main comparison Fertility outcomes for cervical intraepithelial lesions; Summary of findings 2 Early pregnancy outcomes for cervical intraepithelial lesions

\section{Fertility outcomes}

The results of the individual studies on the overall pregnancy rate varied. Two studies did not report any significant differences between groups (Bigrigg 1994; Turlington 1996), while the remaining two described significantly higher overall pregnancy rates for the treated population (Bigrigg 1994; Spitzer 1995). Specifically, Spitzer 1995 reported that women treated with LC or LA had high pregnancy rates compared to untreated women (277/433; $64 \%$ versus $177 / 433 ; 40.9 \%$; RR $1.56,95 \% \mathrm{Cl} 1.37$ to 1.79 ). Similarly, Kallialla 2012 reported higher pregnancy rates for treated (CKC, LLETZ, LC, LA or CT) versus untreated women (2578/6179; $41.7 \%$ versus $11,642 / 30,463 ; 38.2 \%$; RR $1.09,95 \% \mathrm{Cl} 1.06$ to 1.13$)$. The pooled analysis for the overall pregnancy rate assessed in four studies was higher for treated versus untreated women ( $43 \%$ versus $38 \%$; RR $1.29,95 \% \mathrm{Cl} 1.02$ to 1.64 , 4 studies, 38,050 participants; Analysis 1.1; Figure 2), although the heterogeneity of the studies was considerable ( $1288 \%$, P value $<0.00001$, very low quality evidence; Bigrigg 1994; Kallialla 2012; Spitzer 1995; Turlington 1996). 
Figure 2. Forest plot of comparison: 1 Fertility outcomes, outcome: 1.1 Total pregnancy rates.

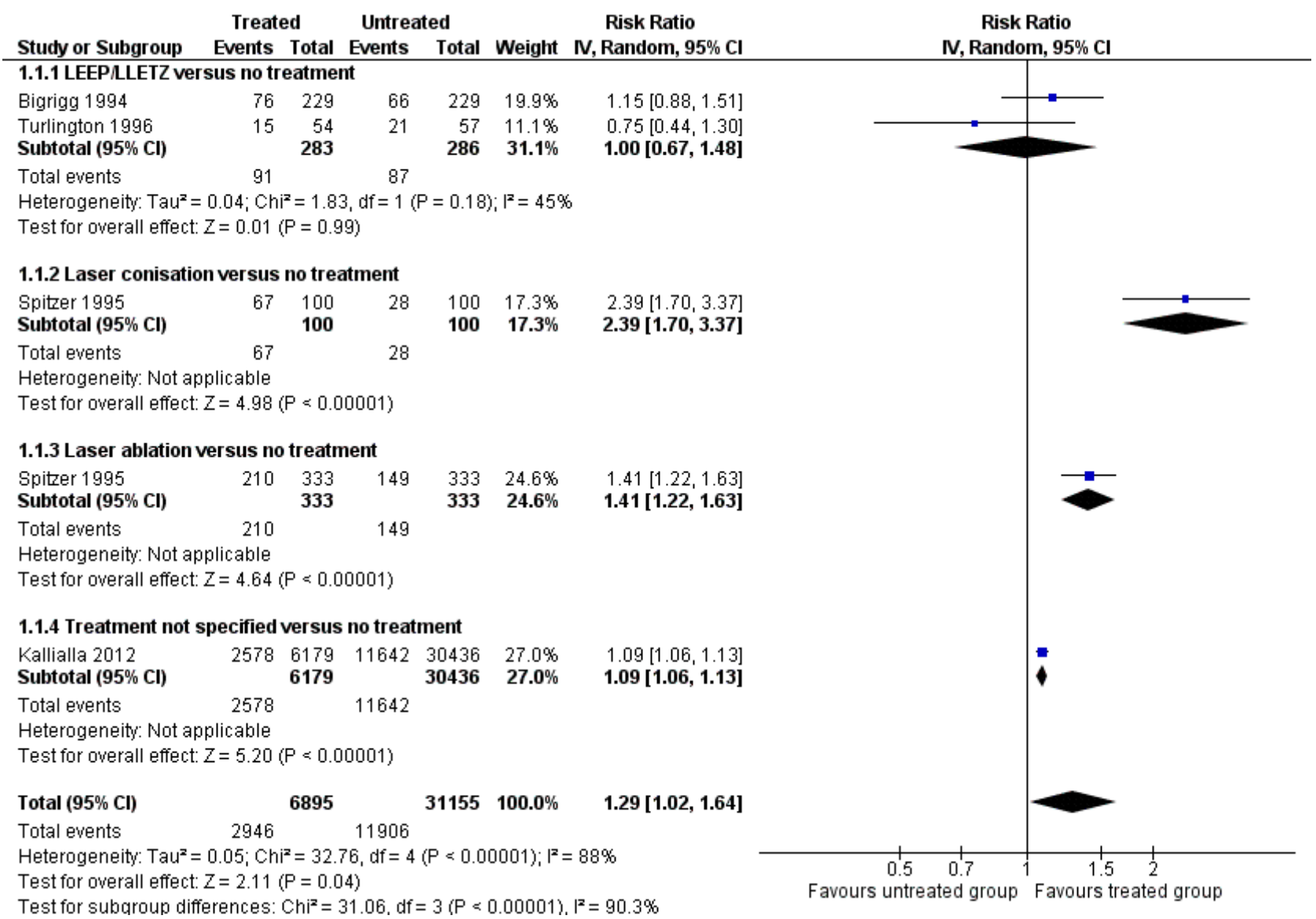

The pregnancy rate in women with an intention to conceive was assessed in two small studies (Turlington 1996; Weber 1979) and was no different for treated compared to untreated women in either study. The pooled meta-analysis also confirmed that there were no significant differences between treated and untreated women ( $87.9 \%$ versus $94.6 \%$; RR $0.93,95 \% \mathrm{Cl} 0.80$ to 1.08 , 2 studies, 70 participants, $120 \%$, P value $=0.77$, very low quality evidence). Both studies were at high risk of publication bias(Analysis 1.2).

The conception rate within a given period was described in three small studies (Bigrigg 1994; Spracklen 2013; Weber 1979). Two studies reported non-significant differences (Bigrigg 1994; Weber 1979), while the third suggested that the proportion of women who required more than 12 months to conceive was significantly higher for treated (all methods, not specified) versus all untreated women (25/152; $16.4 \%$ versus $86 / 1021 ; 8.4 \%$; RR $1.95,95 \% \mathrm{Cl} 1.29$ to 2.95 ) or versus non-treated women attending for colposcopy (13/151; 8.6\%; RR 1.91, 95\% Cl 1.02 to 3.59; Spracklen 2013).
The meta-analysis suggested that treatment did not adversely affect the proportion of women who required more than 12 months to conceive as compared to untreated controls $(14.7 \%$ versus $9.2 \%$, RR $1.45,95 \% \mathrm{Cl} 0.89$ to $2.37, \mathrm{P}$ value $=0.14,3$ studies, 1348 participants, $1246 \%$, very low quality evidence; Analysis 1.8 ; Analysis 1.9) or as compared to women attending colposcopy without receiving treatment $(16.4 \%$ versus $8.6 \%$, RR $1.88,95 \%$ $\mathrm{Cl} 0.99$ to 3.55, 1 study, 303 participants, $\mathrm{I}^{2} 0 \%$, $\mathrm{P}$ value $=0.88$; Analysis 1.11; Analysis 1.12; Figure 3). The proportion of women who required more than 12 months to conceive was also no different for women that had colposcopy as compared to women without CIN (8.6\% versus 8.4\%, RR $1.02,95 \% \mathrm{Cl} 0.59$ to $1.79,1$ study, 1172 participants, $\left.\right|^{2}$ not estimable (NE), P value NE; Analysis 1.10). This comparison demonstrated moderate heterogeneity (12 46\%). The remainder of the intervals to conception that were assessed were also not significantly affected: 
Figure 3. Forest plot of comparison: 1 Fertility outcomes, outcome: 1.9 Conception >12 months (treatment versus no treatment).

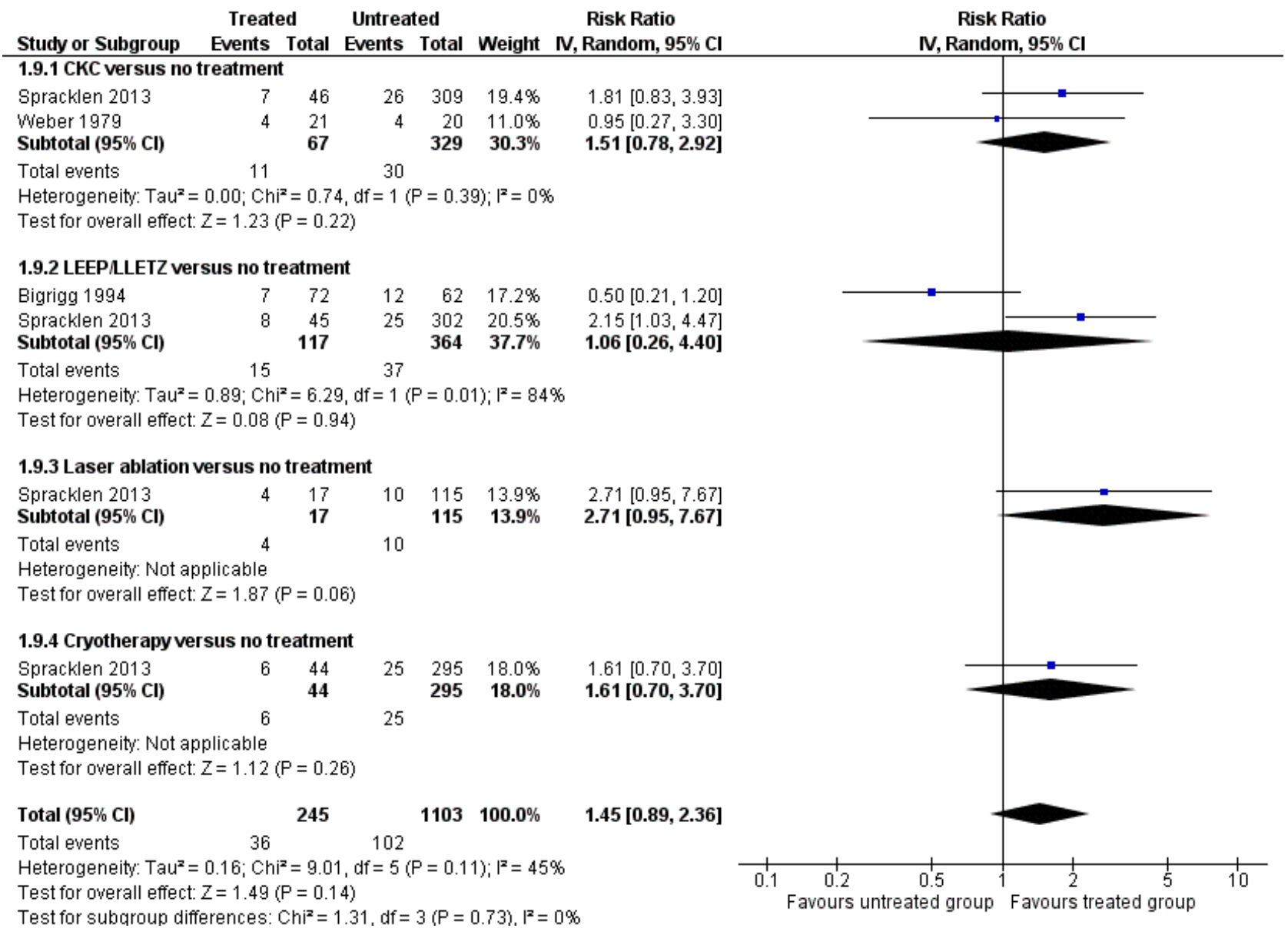

- Conception within 0 to 3 months: $49.5 \%$ versus $54.9 \%$, RR 0.89 , $95 \% \mathrm{Cl} 0.67$ to $1.19,2$ studies, 175 participants, $\mathrm{I}^{2} 0 \%$, $\mathrm{P}$ value $=$ 0.58 (Analysis 1.3);

- Conception within 0 to 6 months: $78.5 \%$ versus $75.6 \%$, RR 1.03 , $95 \% \mathrm{Cl} 0.89$ to $1.19,2$ studies, 175 participants, $120 \%$, $\mathrm{P}$ value $=$ 0.97 (Analysis 1.4);

- Conception 0 to 9 months: $66.7 \%$ versus $65.0 \%, \mathrm{RR} 1.03,95 \% \mathrm{Cl}$ 0.66 to $1.59,1$ study, 41 participants, $I^{2} \mathrm{NE}, \mathrm{P}$ value NE (Analysis 1.5);

- Conception within 0 to12 months: $87.1 \%$ versus $84.1 \%$, RR 1.04 , $95 \% \mathrm{Cl} 0.94$ to $1.16,2$ studies, 175 participants, $120 \%$, $\mathrm{P}$ value $=$ 0.62 (Analysis 1.6);

- Conception within 0 to 24 months: $85.7 \%$ versus $90.0 \%$, RR 0.95, $95 \% \mathrm{Cl} 0.76$ to $1.20,1$ study, 41 participants, I2 NE, P value NE (Analysis 1.7);

- Conception within more than 36 months: $5.5 \%$ versus $8.0 \%$, RR $0.69,95 \% \mathrm{Cl} 0.19$ to $2.45,1$ study, 134 participants, I2 NE, P value NE (Analysis 1.13).

\section{Early pregnancy outcomes}

Early pregnancy outcomes were assessed in 14 studies (Albrechtsen 2008; Bigrigg 1994; Blomfield 1993; Buller 1982; Cruickshank 1995; Frega 2013; Kallialla 2012; Larsson 1982; Sagot 1995; Sjoborg 2007; Spitzer 1995; Tan 2004; Turlington 1996; Weber 1979).

All the studies that reported on the overall miscarriage rate suggested that there was no difference between treated and untreated populations (Bigrigg 1994; Buller 1982; Frega 2013; Kalliala 2012; Larsson 1982; Sagot 1995; Tan 2004; Turlington 1996; Weber 1979), apart from one (Spitzer 1995). Spitzer 1995 reported a protective effect for treated women as compared to untreated controls (11.4\% versus $18.6 \%$; RR $0.60,95 \% \mathrm{Cl} 0.38$ to 0.94 , $\mathrm{P}$ value $=0.03$ ). The pooled analysis for the total miscarriage rate between treated and untreated women demonstrated no significant difference (4.6\% versus $2.8 \%$, RR $1.04,95 \% \mathrm{Cl} 0.90$ to $1.21,10$ studies, 39504 participants, $129 \%$, P value $=0.36$, low quality evidence; Analysis 2.1; Analysis 2.2; Figure 4) for any of the methods assessed. 
Figure 4. Forest plot of comparison: 2 Early pregnancy outcomes, outcome: 2.2 Miscarriage rates (treatment versus no treatment).

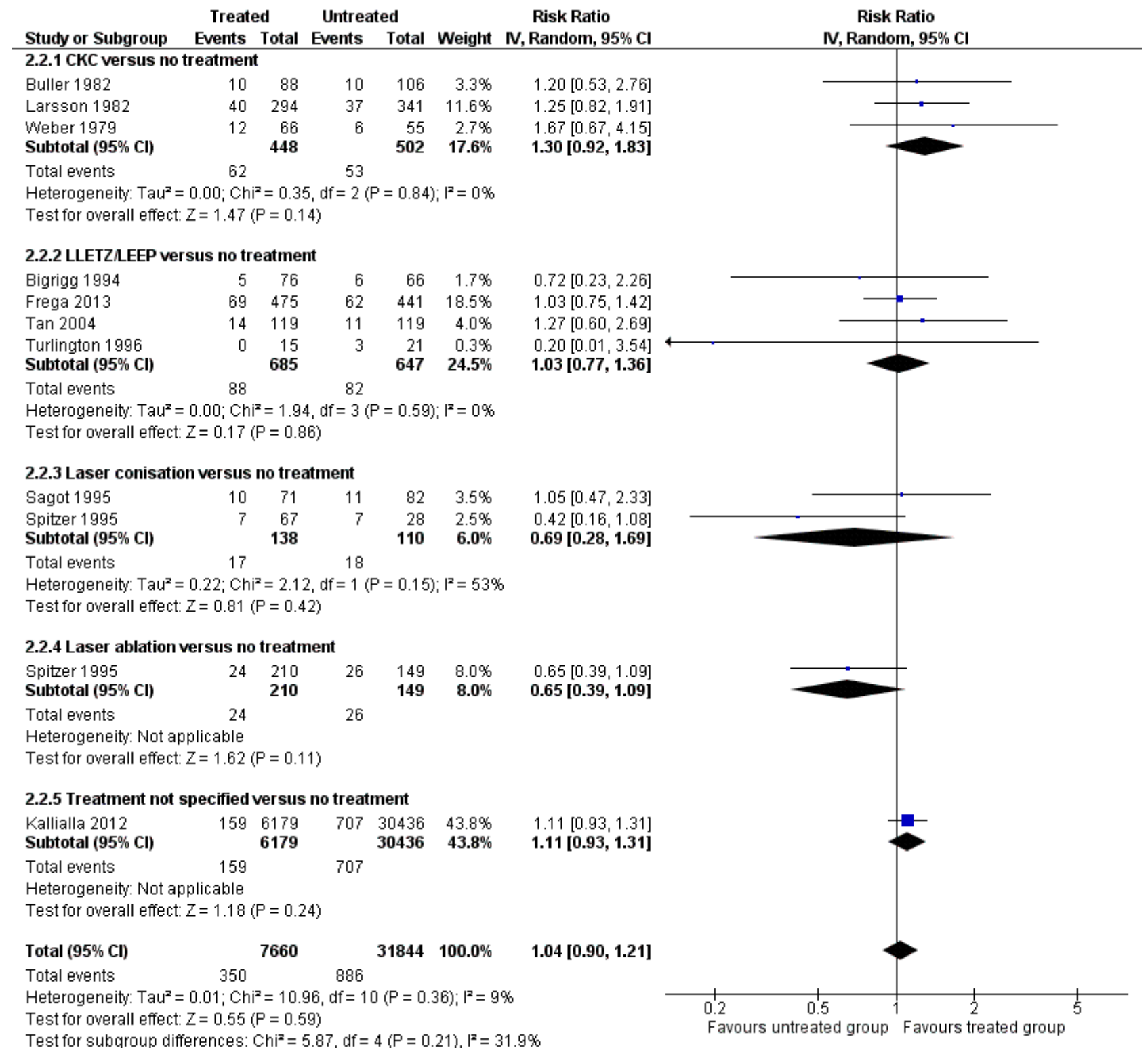

Four studies reported on first trimester miscarriage rates separately (Buller 1982; Larsson 1982; Sagot 1995; Weber 1979); there were no significant differences in any of the included studies. The pooled meta-analysis for first trimester miscarriage rate did not demonstrate a significant difference between treated and untreated women $(9.8 \%$ versus $8.4 \%, \mathrm{RR} 1.16,95 \% \mathrm{Cl} 0.80$ to 1.69 , 4 studies, 1103 participants; $120 \%$, P value $=0.97$, low quality evidence; Analysis 2.3; Figure 5). 
Figure 5. Forest plot of comparison: 2 Early pregnancy outcomes, outcome: 2.3 1st trimester Miscarriage rates (treatment versus no treatment).

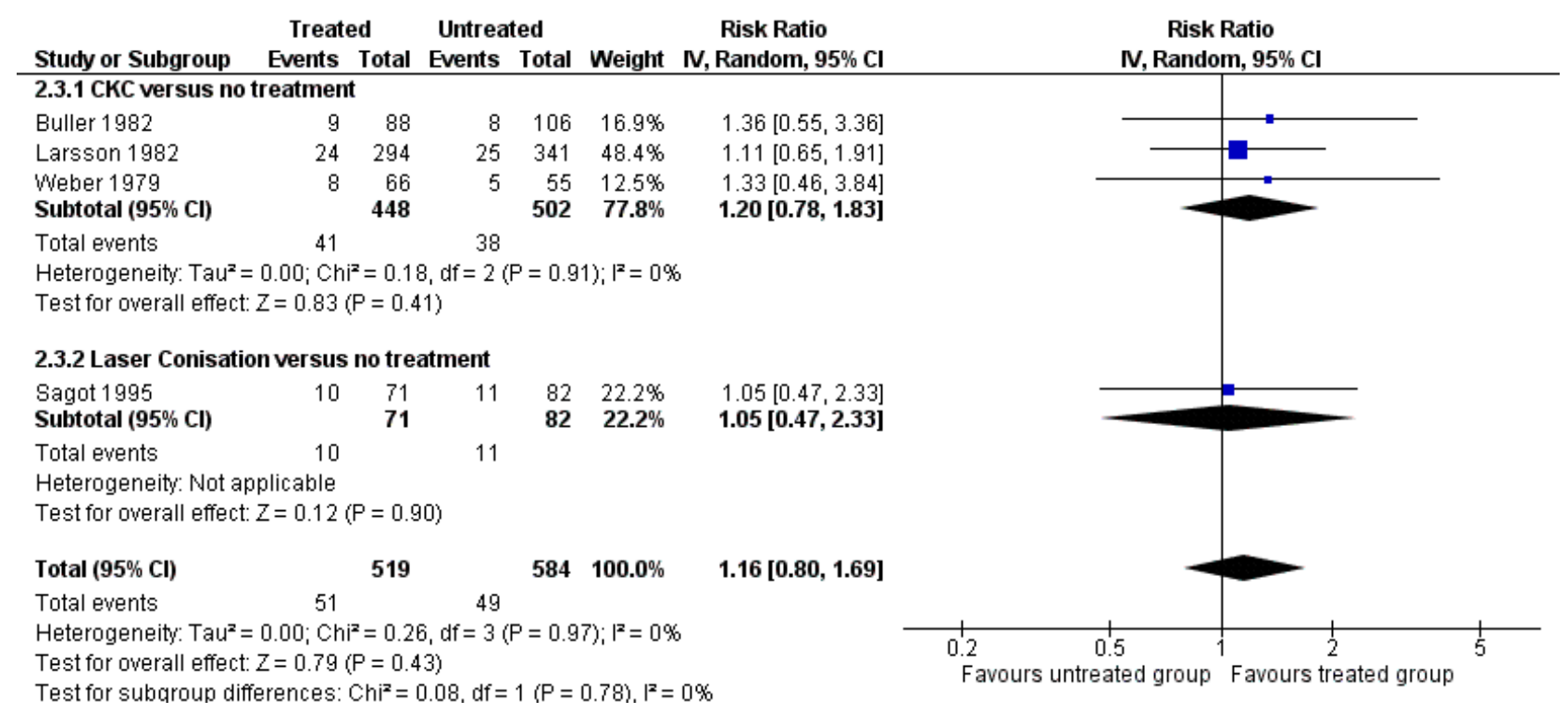

Eight studies reported on second trimester miscarriage rates (Albrechtsen 2008; Blomfield 1993; Buller 1982; Cruickshank 1995; Larsson 1982; Sagot 1995; Sjoborg 2007; Weber 1979). Seven did not report significant differences, whilst one with a large sample size (Albrechtsen 2008) demonstrated that treated women had a higher second trimester miscarriage rate compared to untreated women (226/15,108; $1.5 \%$ versus 8501/2,164,006; 0.4\%; RR 3.81, 95\% Cl 3.34 to 4.34 ) or internal controls $(209 / 57136 ; 0.4 \%$; RR 4.09, 95\% Cl 3.39 to 4.93$)$. In the meta-analysis, we found that cervical treatment significantly increased the risk of second trimester miscarriage.
This outcome was assessed in eight studies and 16,558 treated women. The rate was higher for treated versus untreated women (1.6\% versus $0.4 \%$; RR $2.60,95 \% \mathrm{Cl} 1.45$ to 4.67 , 8 studies, $2,182,268$ participants, $1241 \%$, P value $=0.12$, low quality evidence; Figure 6 , Analysis 2.4). There was moderate inter-study heterogeneity. These results were largely dominated by one large study from Norway that did not control for smoking (Albrechtsen 2008). A sensitivity analysis with the exclusion of this study revealed a similar direction, but smaller magnitude, of the effect size (RR $1.78,95 \% \mathrm{Cl} 0.98$ to 3.20). 
Figure 6. Forest plot of comparison: 2 Early pregnancy outcomes, outcome: 2.4 2nd trimester miscarriage rates (treatment versus no treatment).

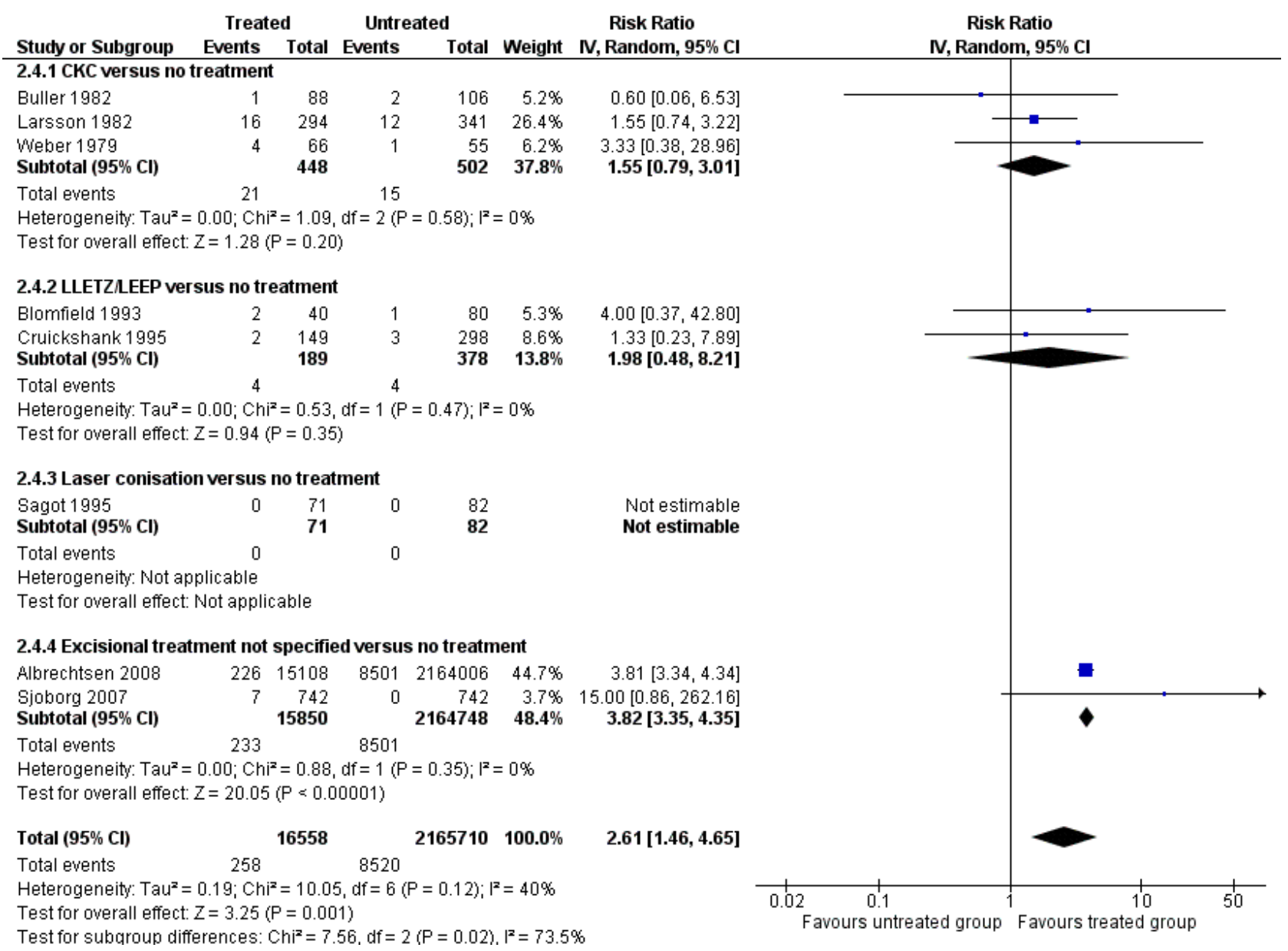

The rate of ectopic pregnancy was also higher for treated compared to untreated women $(1.6 \%$ versus $0.8 \%$; $\mathrm{RR} 1.89,95 \% \mathrm{Cl} 1.50$ to $2.39,6$ studies, 38,193 participants, $120 \%$, P value $=0.44$, low quality evidence; Analysis 2.5; Analysis 2.6), while the molar pregnancy rate did not differ ( Analysis 2.7). The termination of pregnancy rate was higher in women with a history of treatment compared to untreated controls (12.2\% versus $7.4 \%$ ) with moderate heterogeneity (RR 1.71, $95 \% \mathrm{Cl} 1.31$ to $2.22,7$ studies, 38,208 participants, $1241 \%$, $\mathrm{P}$ value $=$ 01.0, low quality evidence; Analysis 2.8; Analysis 2.9).

\section{DISCUSSION}

\section{Summary of main results}

This systematic review and meta-analysis suggests that local conservative cervical treatment for $\mathrm{CIN}$ does not adversely affect fertility outcomes. Pregnancy rates for treated women with an intention to conceive were comparable and the overall pregnancy rate was higher as compared to untreated controls. However, heterogeneity across studies was considerable. The higher pregnancy rate noted in the treated population may be explained by behavioural characteristics in women with $\mathrm{CIN}$ (Kallialla 2012), possibly affected by their increased anxiety with regard to their future fertility. The conception rate within a given post-treatment period did not differ for treated and untreated women. There was a suggestion that treated women took longer to conceive, but the number of studies was small and the difference was not significant. Although these findings raise the question as to whether treatment prolongs the time to conception, the results may also be explained by clinicians' recommendations and patients' preference to avoid conception during the early postoperative period or until the first follow-up assessment confirms the absence of residual disease.

The meta-analysis also suggested that conservative cervical treatment for CIN may increase the risk of second trimester miscarriage. The results of the analysis on mid-trimester losses were dominated by one large study (Albrechtsen 2008). This study did not control for smoking and did not provide data for the individual treatment techniques (knife, laser, LLETZ). The results of this study were consistent with the remaining studies, and its exclusion from the analysis did not change the direction of the effect. The total and first trimester miscarriage rates were similar for treated and untreated populations. The higher number of ectopic pregnancies and terminations in the treated population possibly reflects the characteristics of women with $\mathrm{CIN}$, who are known to be at a higher risk of sexually transmitted disease and unplanned pregnancies (Kallialla 2012). This also highlights the limitations of cohort studies, since the groups are not identical for other risk factors likely to affect pregnancy outcomes. 
The results of this review should be interpreted with caution, as the included studies were often retrospective, at high risk of recall bias and with inadequate adjustment for possible confounders. The analysis included studies with different designs, using comparisons between and among women and mixed matching.

\section{Overall completeness and applicability of evidence}

The choice of comparison group may substantially affect the result of the analysis. Six studies matched for known confounders, three adjusted for these in a regression analysis, five used comparisons of the same women before and after treatment and only two used as comparators women who attended colposcopy, had a biopsy, but were not treated. The use of untreated controls without the CIN may not account for occult confounders and may over-inflate the effect of treatment (Bruinsma 2011; Kyrgiou 2012). A sensitivity analysis that excluded the studies that used internal controls and another that excluded old and/or poor quality studies did not change the direction or the magnitude of the effect of the meta-analysis. It was not possible to carry out subgroup analyses for the comparison groups separately, due to the limited number of studies in each group.

We analysed the results for the individual treatment techniques separately for excision and ablation, and for all the techniques jointly. The numbers of studies was small and the analyses of the individual techniques did not have sufficient sample sizes to support definite conclusions.

Analyses that would stratify according to the length of the cone or parity were also not feasible, as these data were not reported by the individual studies. It is likely that the risk of second trimester miscarriage increases with increasing cone length or/and cervical proportion removed, similar to the effect seen for the risk of preterm birth (Castanon 2014b; Kyrgiou 2012; Kyrgiou 2015; Khalid 2012). The inability to adjust for the cone length may mask the true effect that deep cervical treatments may have on fertility and may, conversely, over-inflate the risk that small treatments $(<10 \mathrm{~mm}$ in cone length) may have on the risk of mid-trimester loss.

Furthermore, an analysis of the second trimester miscarriage risk or the ability to conceive stratified by the length of the interval from treatment to pregnancy, or first attempt to conceive, was not possible, as these data were not reported and could not be extrapolated from any of the included studies. It is likely that some women were advised by their clinicians to delay conception for a few months post-treatment. A large population-based Finnish cohort recently documented that the interval between treatment and pregnancy does not impact on the risk of preterm birth (Heinonen 2013). Assuming that the mechanism for mid-trimester loss and preterm birth after cervical treatment is common, this may also be the case for second trimester miscarriages.

\section{Quality of the evidence}

The included studies were heterogeneous in their design, comparison group and outcomes. The number of studies and the study size were small for many of the reported outcomes and the outcomes of interest were difficult to objectively measure. Although the inter-study heterogeneity was non-significant (apart from the analysis of the total pregnancy rates), the number of studies was small and the effect of the meta-analysis could be affected by the addition of one large study. The sensitivity analysis that excluded some of the largest studies did not change the results.

The quality of the evidence based on the GRADE assessment was very low for the fertility outcomes (Summary of findings for the main comparison) and low for all early pregnancy analyses (Summary of findings 2). All of the included studies described retrospective non-randomised cohorts; there was only one prospective study (Frega 2013). Two of the observational cohort studies were population-based studies from Finland and Norway (Albrechtsen 2008; Kallialla 2012) with big populations and large magnitudes of effect and could be upgraded to moderate quality. Some other studies had limitations in the design with high risk of bias: they were small with a study group that was not representative of the whole population, had a low response rate to questionnaires and had wide confidence intervals; these were downgraded to very low quality (Bigrigg 1994; Cruickshank 1995; Turlington 1996; Weber 1979).

\section{Potential biases in the review process}

All the included studies, apart from one (Frega 2013), described retrospective cohorts that are prone to bias. As the evidence is not based on RCTs, this analysis demonstrates an association but not necessarily a causative relationship.

The data were derived from self-reports, clinic data sets, telephone contacts, postal questionnaires or national registries and may represent incomplete and selected data. Early pregnancy outcomes (before the age of viability) are less well reported than outcomes in the third trimester. The level of over-reporting or under-reporting may be different for treated and untreated women and the impact that this may have is difficult to assess. Reporting may be better in the treated group owing to easier access to gynaecological services, or it could be lower in women with CIN, who often belong to lower socioeconomic classes that are likely to be less compliant with recommended medical care. It is also often difficult to accurately assess fertility end-points, as the causes of subfertility may vary substantially (i.e. partner's fertility, tubal factor, age, ovarian reserve, lifestyle) and elimination of all confounders may be impossible.

Given the non-randomised nature of the included studies, the choice of comparison group may impact on the risk estimate for each reported outcome (Kyrgiou 2012). Baseline imbalances in the compared groups may substantially impact on the results. For example, the lack of control for smoking is likely to introduce bias, as smoking has been correlated with adverse reproductive outcomes. A meta-analysis on the impact of cervical treatment on preterm birth reported that studies using external comparators may over-inflate the effect caused by treatment (Bruinsma 2011). This effect is less pronounced for studies using internal controls, while those using women with CIN but no treatment as a comparison group are less likely to report an effect size largely affected by confounders (Bruinsma 2011). There were only two studies in this meta-analysis that used women who had colposcopy and biopsy, but no treatment as comparators (Spracklen 2013; Turlington 1996), and they reported on different outcomes.

Many of the studies relied on data collected from structured interviews and mailed questionnaires with low response rates, at high risk of incomplete outcome data (attrition bias). These studies were also at risk of misclassification and recall bias. 
We only included cohorts comparing treated women with untreated populations. As treatment is offered on the basis of a precancerous disease, randomised studies are unlikely to be conducted. Randomised studies comparing different techniques with regard to reproductive outcomes were not found and may never be conducted. Although the comparisons of treated versus untreated women are prone to bias, this analysis provides the best possible level of evidence to date, despite limitations.

We used for the analyses unadjusted data and this may have introduced bias. The adjusted analysis for the two largest studies (Albrechtsen 2008; Kallialla 2012) had similar results to the unadjusted one and therefore it is unlikely that adjustment would alter the results of the meta-analysis.

In order to minimise bias whilst undertaking the review, the retrieved citations and the extracted data were independently reviewed by two authors (MK and AM). There were no discrepancies in the included studies; some minor discrepancies in the data extraction were resolved with discussion and the involvement of a third reviewer (MA) when necessary.

\section{Agreements and disagreements with other studies or reviews}

Treatment of CIN has been associated with an increased risk of adverse obstetric sequelae and preterm birth in subsequent pregnancies (Arbyn 2008; Bruinsma 2011; Kyrgiou 2006; Kyrgiou 2012; Jakobsson 2007). More recent data suggests that CIN itself, or confounders in women that have the disease, may partly contribute to that risk (Bruinsma 2011; Castanon 2012). Increasing evidence also suggests that the size (length) of the cone influences the frequency and severity of premature birth (Arbyn 2014; Castanon 2014b; Founta 2010; Khalid 2012; Kyrgiou 2012; Noehr 2009).

A systematic review that focused mainly on obstetric outcomes after cervical treatment also reported on studies assessing the impact of treatment on fertility (Kyrgiou 2006). A meta-analysis on fertility outcomes was not possible due to the limited number of published reports at the time. Assessment of the individual studies in this review did not suggest any impact of treatment on fertility. No systematic review and meta-analysis reported on the risk of second trimester miscarriage. The results are consistent with a previously published version of this review (Kyrgiou 2014).

The results are also consistent with large population-based studies included in the review (Albrechtsen 2008; Kallialla 2012).

\section{AUTHORS' CONCLUSIONS}

\section{Implications for practice}

This meta-analysis suggests that treatment for CIN is unlikely to have an adverse effect on fertility, although treatment was associated with an increased risk of miscarriage in the second trimester. These results should be interpreted with caution, as the included studies were non-randomised and many were of low/very low quality and at high risk of bias. Although we did demonstrate an association between treatment and mid-trimester miscarriage, we did not prove causality.

The risk of second trimester miscarriages for less aggressive local treatments and small cone length (i.e. a small LLETZ) and conversely the risk of subfertility following more aggressive treatment could not be stratified and remains unclear. Furthermore, we were not able to assess whether the interval from treatment to pregnancy or first attempt to conceive affects the outcomes. These were not found to be important determinants of the obstetric outcomes in a previously published population-based study (Heinonen 2013).

Women with subfertility and a history of cervical treatment should be informed that this is unlikely to be related to their treatment. Women enquiring about the impact that cervical treatment may have on their fertility should be advised that fertility is not compromised. Women in the early weeks of pregnancy or preconception should be informed that cervical treatment may be related to an increased risk of second trimester loss (as well as preterm birth) and that they may require more intensive surveillance antenatally.

Although we were unable to stratify the risk of second trimester miscarriages according to the length of the cone, there is evidence that the amount of tissue removed correlates to the risk of preterm birth in women after excisional treatment of the cervix (Castanon 2014a; Founta 2010; Kyrgiou 2006; Kyrgiou 2015; Noehr 2009). It would seem prudent to remove as little tissue as necessary, especially in nulliparous women with a small cervix, without compromising the eradication of the disease. More sensitive tests, such as those for human papillomavirus (HPV) DNA, should be used to improve the detection of residual or recurrent lesions after treatment and to minimise the risk of future cancer in young women (Arbyn 2012). Every effort should be made to optimise both reproductive and oncological outcomes for women requiring treatment (Arbyn 2014; Strander 2014).

\section{Implications for research}

It may be that intrinsic deficiencies in the immune defences of some women make them more prone to ascending infections and persistent HPV infection. Conversely, HPV infection itself may have an effect on antimicrobials in the cervical mucus (Kyrgiou 2015).

Future large, well designed, non-randomised studies are required to carefully explore possible associations between treatment for CIN and subsequent fertility and early and late pregnancy outcomes, stratifying by cone length, proportion of cervix excised or ablated, interval from treatment to conception and treatment technique. Research activities should include prospective collection of cohorts with careful documentation of confounders and should include only women with an intention to conceive for the reporting of the fertility outcomes. As the impact of ablative techniques on the risk of second trimester miscarriage has never been explored, this should be further evaluated or explored in the context of a randomised head-to-head comparison of excision versus ablation.

The exact mechanism that explains the increased risk of second trimester loss and preterm birth associated with CIN and its treatment is unclear. Although most obstetricians would think that this increase in risk is related to cervical incompetence, histological changes in the healed cervix (Phadnis 2011) or changes in the innate immune system and the vaginal microenvironment are probably important contributors. The uterus in pregnancy is protected from ascending infection by the cervix, its mucous plug and its synthesis of antibacterial compounds and by a 'benign' Lactobacillusdominated vaginal microflora (Ravel 2011). There is a clear link 
between infection/inflammation and preterm birth. Removing part of the cervix, or simply its infection with HPV, may impair the host's defence mechanisms, the chemical microenvironment and, as a result, the vaginal microbiome producing natural antimicrobials (Human Microbiome Project Consortium 2012). It may also be that intrinsic deficiencies in the immune defences of certain individuals make them more prone to ascending infections when pregnant, but also HPV persistence and precancer (Kyrgiou 2015).

A better understanding of these factors may enable selection of women at risk for $\mathrm{CIN}$, and prevention with cause-directed strategies (Holmes 2012a; Holmes 2012b; Jimenez 2013; Li 2011; Nicholson 2012).

\section{ACK N O WLEDGEMENTS}

We thank Jo Morrison, Clare Jess, Jane Hayes and Andy Bryant of the CGCRG editorial team for their contribution to the editorial process. We thank the referees for their many helpful suggestions.

This project was supported by the National Institute for Health Research (NIHR), via Cochrane Infrastructure funding to the Cochrane Gynaecological, Neuro-oncology and Orphan Cancer Group. The views and opinions expressed herein are those of the authors and do not necessarily reflect those of the Systematic Reviews Programme, NIHR, National Health Service or the Department of Health. 


\section{REFERE N CES}

\section{References to studies included in this review}

Albrechtsen 2008 \{published data only\}

Albrechtsen S, Rasmussen S, Thoresen S, Irgens LM, Iversen OE. Pregnancy outcome in women before and after cervical conisation: population based cohort study. BMJ 2008;337:a1343

\section{Bigrigg 1994 \{published data only\}}

Bigrigg A, Haffenden DK, Sheehan AL, Codling BW, Read MD. Efficacy and safety of large loop excision of the transformation zone. Lancet 1994;343:32-4.

\section{Blomfield 1993 \{published data only\}}

Blomfield PI, Buxton J, Dunn J, Luesley DM. Pregnancy outcome after large loop excision of the cervical transformation zone. American Journal of Obstetrics and Gynecology 1993;169(3):620-5

\section{Buller 1982 \{published data only\}}

Buller RE, Jones HW. Pregnancy following cervical conization. American Journal of Obstetrics and Gynecology 1982;142(5):506-12.

\section{Cruickshank 1995 \{published data only\}}

Cruickshank ME, Flannelly G, Campbell DM, Kitchener HC. Fertility and pregnancy outcome following large loop excision of the cervical transformation zone. British Journal of Obstetrics and Gynaecology 1995;102(6):467-70.

Frega 2013 \{published data only\}

Frega A, Sesti F, De Sanctis L, Pacchiarotti A, Votano S, Biamonti A, et al. Pregnancy outcome after loop electrosurgical excision procedure for cervical intraepithelial neoplasia. International Journal of Gynecology \& Obstetrics 2013;122(2):145-9.

Kallialla 2012 \{published data only\}

Kalliala I, Anttila A, Dyba T, Hakulinen T, Halttunen M, Nieminen P. Pregnancy incidence and outcome among patients with cervical intraepithelial neoplasia: a retrospective cohort study. British Journal of Obstetrics and Gynaecology 2012;119(2):227-35.

\section{Larsson 1982 \{published data only\}}

Larsson G, Grundsell H, Gullberg B, Svennerud S. Outcome of pregnancy after conization. Acta Obstetricia et Gynecologica Scandinavica 1982;61(5):461-6.

\section{Sagot 1995 \{published data only\}}

Sagot P, Caroit Y, Winer N, Lopes P, Boog G. Obstetrical prognosis for carbon dioxide laser conisation of the uterine cervix. European Journal of Obstetrics \& Gynecology andReproductive Biology 1995;58(1):53-8.

\section{Sjoborg 2007 \{published data only\}}

Sjøborg KD, Vistad I, Myhr SS, Svenningsen R, Herzog C, Kloster-Jensen A, et al. Pregnancy outcome after cervical cone excision: a case-control study. Acta Obstetricia et Gynecologica Scandinavica 2007;86(4):423-8.

Spitzer 1995 \{published data only\}

Spitzer M, Herman J, Krumholz BA, Lesser M. The fertility of women after cervical laser surgery. Obstetrics \& Gynecology 1995;86(4):504-8.

\section{Spracklen 2013 \{published data only\}}

Spracklen CN, Harland KK, Stegmann BJ, Saftlas AF. Cervical surgery for cervical intraepithelial neoplasia and prolonged time to conception of a live birth: a case-control study. British Journal of Obstetrics and Gynaecology 2013;120(8):960-5.

\section{Tan 2004 \{published data only\}}

Tan L, Pepra E, Haloob RK. The outcome of pregnancy after large loop excision of the transformation zone of the cervix. Journal of Obstetrics \& Gynaecology 2004;24(1):25-7.

Turlington 1996 \{published data only\}

Turlington WT, Wright BD, Powell JL. Impact of the loop electrosurgical excision procedure on future fertility. The Journal of Reproductive Medicine 1996;41(11):815-8.

Weber 1979 \{published data only\} Weber T, Obel EB. Pregnancy complications following conization of the uterine cervix. Acta Obstetricia et Gynecologica Scandinavica 1979;58:347-51.

\section{References to studies excluded from this review}

Acharya 2004 \{published data only\}

Acharya G, Kjeldberg I, Hansen SM, Sørheim N, Jacobsen BK, Maltau JM. Pregnancy outcome after loop electrosurgical excision procedure for the management of cervical intraepithelial neoplasia. Archives of Gynecology and Obstetrics 2005;272(2):109-12.

Anderson 1984 \{published data only\}

Anderson MC, Horwell DH, Broby Z. Outcome of pregnancy after laser vaporization conization. Journal of Gynecologic Surgery 1984;1 (1):35-9.

\section{Armarnik 2011 \{published data only\}}

Armarnik S, Sheiner E, Piura B, Meirovitz M, Zlotnik A, Levy A. Obstetric outcome following cervical conization. Archives of Gynecology and Obstetrics 2011;283:765-9.

\section{Berretta 2013 \{published data only\}}

Berretta R, Gizzo S, Dall'Asta A, Mazzone E, Monica M, Franchi L, et al. Risk of preterm delivery associated with prior treatment of cervical precancerous lesion according to the depth of the cone. Disease Markers 2013;35(6):721-6.

Braet 1994 \{published data only\}

Braet PG, Peel JM, Fenton DW. A case controlled study of the outcome of pregnancy following loop diathermy excision of 
the transformation zone. Journal of Obstetrics and Gynaecology 1994; 19:79-82.

\section{Conner 2013 \{published data only\}}

Conner SN, Cahill AG, Tuuli MG, Stamilio DM, Odibo AO, Roehl KA, et al. Interval from loop electrosurgical excision procedure to pregnancy and pregnancy outcomes. Obstetrics \& Gynecology 2013;122(6):1154-9.

\section{Ferenczy 1995 \{published data only\}}

Ferenczy A, Choukroun D, Falcone T, Franco E. The effect of cervical loop electrosurgical excision on subsequent pregnancy outcome: North American experience. American Journal of Obstetrics and Gynecology 1995;172(4):1246-50.

\section{Forsmo 1996 \{published data only\}}

Forsmo S, Hansen MH, Jacobsen BK, Oian P. Pregnancy outcome after laser surgery for cervical intraepithelial neoplasia. Acta Obstetricia et Gynecologica Scandinavica 1996;75(1):139-43.

\section{Gordon 1991 \{published data only\}}

Gordon HK, Duncan ID. Effective destruction of cervical intraepithelial neoplasia (CIN) 3 at $100^{\circ}$ Cusing the Semm cold coagulator: 14 years experience. British Journal of Obstetrics and Gynaecology 1991;98(1):14-20.

\section{Haffenden 1993 \{published data only\}}

Haffenden DK, Bigrigg A, Codling BW, Read MD. Pregnancy following large loop excision of the transformation zone. British Journal of Obstetrics and Gynaecology 1993;100(11):1059-60.

\section{Hagen 1993 \{published data only\}}

Hagen B, Skjeldestad FE. The outcome of pregnancy after CO, laser conisation of the cervix. British Journal of Obstetrics and Gynaecology 1993;100:717-20.

\section{Jones 1979 \{published data only\}}

Jones JM, Sweetnam P, Hibbard BM. The outcome of pregnancy after cone biopsy of the cervix: a case-control study. British Journal of Obstetrics and Gynaecology 1979;86(12):913-6.

\section{Keijser 1992 \{published data only\}}

Keijser KG, Kenemans P, van der Zanden PH, Schijf CP, Vooijs GP, Rolland R. Diathermy loop excision in the management of cervical intraepithelial neoplasia: diagnosis and treatment in one procedure. American Journal of Obstetrics \& Gynecology 1992;166(4):1281-7.

\section{Khalid 2012 \{published data only\}}

Khalid S, Dimitriou E, Conroy R, Paraskevaidis E, Kyrgiou M, Harrity $C$, et al. The thickness and volume of LLETZ specimens can predict the relative risk of pregnancy-related morbidity. British Journal of Obstetrics and Gynaecology 2012;119(6):685-91.

\section{Kuoppala 1986 \{published data only\}}

Kuoppala T, Saarikoski S. Pregnancy and delivery after cone biopsy of the cervix. Archives of Gynecology and Obstetrics 1986;237(3):149-54.

\section{Luesley 1985 \{published data only\}}

Luesley DM, McCrum A, Terry PB, Wade-Evans T, Nicholson HO, Mylotte MJ, et al. Complications of cone biopsy related to the dimensions of the cone and the influence of prior colposcopic assessment. British Journal of Obstetrics and Gynaecology 1985;92(2):158-64.

Macvicar 1968 \{published data only\}

Macvicar J, Willocks J. The effect of diathermy conization of the cervix on subsequent fertility, pregnancy and delivery. Journal of Obstetrics \& Gynaecology of the British Commonwealth 1968;75(3):355-6.

\section{Mathevet 2003 \{published data only\}}

Mathevet P, Chemali E, Roy M, Dargent D. Long-term outcome of a randomized study comparing three techniques of conization: cold knife, laser, and LEEP. European Journal of Obstetrics \& Gynecology and Reproductive Biology 2003;106(2):214-8.

\section{Mazouni 2005 \{published data only\}}

Mazouni C, Porcu G, Haddad O, Dalès JP, Taranger-Charpin C, Piana $L$, et al. Conservative treatment of cervical intraepithelial neoplasia using a cold-knife section technique. European Journal of Obstetrics \& Gynecology and Reproductive Biology 2005;121(1):86-93.

\section{Michelin 2009 \{published data only\}}

Michelin MA, Merino LM, Franco CA, Murta EF. Pregnancy outcome after treatment of cervical intraepithelial neoplasia by the loop electrosurgical excision procedure and cold knife conization. Clinical and Experimental Obstetrics \& Gynecology 2009;36(1):17-9.

\section{Paraskevaidis 2002 \{published data only\}}

Paraskevaidis E, Koliopoulos G, Lolis E, Papanikou E, MalamouMitsi V, Agnantis NJ. Delivery outcomes following loop electrosurgical excision procedure for microinvasive (FIGO stage IA1) cervical cancer. Gynecologic Oncology 2002;86(1):10-3.

\section{Raio 1997 \{published data only\}}

Raio L, Ghezzi F, Di Naro E, Gomez R, Lüscher KP. Duration of pregnancy after carbon dioxide laser conization of the cervix: influence of cone height. Obstetrics \& Gynecology 1997;90(6):978-82.

\section{Shanbhag 2009 \{published data only\}}

Shanbhag S, Clark H, Timmaraju V, Bhattacharya S, Cruickshank M. Pregnancy outcome after treatment for cervical intraepithelial neoplasia. Obstetrics \& Gynecology 2009;114(4):727-35.

\section{van de Vijver 2010 \{published data only\}}

van de Vijver A, Poppe W, Verguts J, Arbyn M. Pregnancy outcome after cervical conisation: a retrospective cohort study in the Leuven University Hospital. British Journal of Obstetrics and Gynaecology 2010;117(3):268-73. 


\section{References to studies awaiting assessment}

\section{Castanon 2013 \{published data only\}}

Castanon A. Risk of preterm delivery after treatment for cervical intraepithelial neoplasia in England, United Kingdom. Conference: RCOG World Congress 2013 Liverpool United Kingdom. BJOG: An International Journal of Obstetrics and Gynaecology. 2013.

\section{Castanon 2014a \{published data only\}}

Castanon A, Landy R, Brocklehurst P, Evans H, Peebles D, Singh N, et al. Risk of preterm delivery with increasing depth of excision for cervical intraepithelial neoplasia in England: nested case-control study. Conference: Perinatal Medicine 2014 Harrogate United Kingdom. Archives of Disease in Childhood: Fetal and Neonatal Edition. 2014.

\section{Chatterjee 2014 \{published data only\}}

Chatterjee S. Oncological and obstetric outcomes of excisional treatment for cervical cancer precursors in reproductive age women. 61st Annual Scientific Meeting of the Society for Gynecologic Investigation, SGI 2014 Florence Italy. Reproductive sciences. 2014

\section{Gay 2009 \{published data only\}}

Gay C. Cervical intraepithelial neoplasia (CIN2+) management: Post treatment complications. Conference: 19th FIGO World Congress of Gynecology and Obstetrics Cape Town South Africa. International Journal of Gynecology and Obstetrics. 2009.

\section{Hong 2014 \{published data only\}}

Hong J. Comparison of clinical outcomes in patients with high-grade cervical intraepithelial neoplasia undergoing bovie electroknife conization versus cold knife conization. Conference: 15th Biennial Meeting of the International Gynecologic Cancer Society Melbourne, VIC Australia. International Journal of Gynecological Cancer. 2014.

\section{Hongo 2012 \{published data only\}}

Hongo A. Analysis of pregnancy outcome after laser conization. Conference: 14th Biennial Meeting of the International Gynecologic Cancer Society, IGCS 2012 Vancouver, BC Canada. International Journal of Gynecological Cancer. 2012.

\section{Jolley 2010 \{published data only\}}

Jolley, J. The relationship between previous cervical surgery and gestational age at delivery in twin gestations. Conference: 2010 30th Annual Meeting of the Society for Maternal-Fetal Medicine, SMFM Chicago, IL United States. American Journal of Obstetrics and and Gynecology. 2010.

\section{Khan 2014 \{published data only\}}

Khan N. Reproductive outcome after cone biopsy in a low resource setting in Nigeria. Conference: 3rd Regional International Gynecologic Cancer Society, IGCS Meeting 2014 Cape Town South Africa. International Journal of Gynecological Cancer. 2014

\section{Kundu 2014 \{published data only\}}

Kundu R. Pregnancy outcome following large loop excision of transformation zone treatment in an University Hospital,
Ireland. Conference: RCOG World Congress 2014 Hyderabad India. BJOG: An International Journal of Obstetrics and Gynaecology. 2014.

\section{Kyrgiou 2013 \{published data only\}}

Kyrgiou M. Proportion of excision, cervical healing and pregnancy outcomes after large loop excision of the transformation zone for cervical intraepithelial Neoplasia. Conference: 60th Annual Scientific Meeting of the Society for Gynecologic Investigation, SGI 2013 Orlando, FL United States. Reproductive Sciences. 2013.

\section{Kyrgiou 2013b \{published data only\}}

Kyrgiou M. Cervical-length indicated cervical cerclage versus routine antenatal care after treatment for cervical precancer. Conference: 60th Annual Scientific Meeting of the Society for Gynecologic Investigation, SGI 2013 Orlando, FL United States. Reproductive Sciences. 2013.

\section{Kyrgiou 2014 \{published data only\}}

Kyrgiou M. Proportion of cervical excision for $\mathrm{CIN}$ as a predictor of future pregnancy outcomes: A prospective study. 61st Annual Scientific Meeting of the Society for Gynecologic Investigation, SGI 2014 Florence Italy. Reproductive Sciences. 2014.

\section{Liu 2009 \{published data only\}}

Liu Z. Data analysis of 18 cases of the pregnancy with cervical epithelial neoplasia. Conference: 19th FIGO World Congress of Gynecology and Obstetrics Cape Town South Africa. International Journal of Gynecology and Obstetrics. 2009.

\section{McGee 2012 \{published data only\}}

McGee J. Adverse obstetrical outcomes associated with treatment for cervical intraepithelial Neoplasia. Conference: 14th Biennial Meeting of the International Gynecologic Cancer Society, IGCS 2012 Vancouver, BC Canada. International Journal of Gynecological Cancer. 2012.

\section{Mozo De Rosales 2009 \{published data only\}}

Mozo De Rosales, F. Conization vs cervical pathology. Which is the real risk factor for prematurity? Conference: 19th FIGO World Congress of Gynecology and Obstetrics Cape Town South Africa. International Journal of Gynecology and Obstetrics. 2009.

\section{Nehls 2010 \{published data only\}}

Nehls K. Conization of the cervix during pregnancy: A retrospective study. Conference: 58th Congress of the German Society for Gynecology and Obstetrics. Archives of Gynecology and Obstetrics. 2010.

\section{Papoutsis 2013 \{published data only\}}

Papoutsis D. The SATH study: Preterm delivery rates in women following a first and second LLETZ conisation for CIN pathology. Conference: RCOG World Congress 2013 Liverpool United Kingdom. BJOG: An International Journal of Obstetrics and Gynaecology. 2013.

\section{Peebles 2013 \{published data only\}}

Peebles D. Risk of preterm delivery after treatment for cervical intraepithelial neoplasia. Conference: 59th Annual Scientific 
Meeting of the Society for Gynecologic Investigation, SGI 2012 San Diego, CA United States. Reproductive Sciences. 2012.

\section{Pinborg 2014 \{published data only\}}

Pinborg A, Ortoft G, Loft A, Ingerslev HJ. Cervical conisation doubles the risk of preterm and very preterm delivery in ART twins-national controlled cohort study. Conference: 70th Annual Meeting of the American Society for Reproductive Medicine, ASRM 2014 Honolulu, HI, United States. Fertility \& sterility. 2014.

\section{Ruengkhachorn 2013 \{published data only\}}

Ruengkhachorn I. Long term outcomes of loop electrosurgical excision procedure for cervical Neoplasia in a high-incidence country. Conference: 18th International Meeting of the European Society of Gynaecological Oncology, ESGO 2013 Liverpool United Kingdom. International Journal of Gynecological Cancer. 2013.

\section{Smrkolj 2009 \{published data only\}}

Smrkolj Eren M. The conservative management of patients with microinvasive cervical cancer. Conference: 19th FIGO World Congress of Gynecology and Obstetrics Cape Town South Africa. International Journal of Gynecology and Obstetrics. 2009.

\section{Song 2009 \{published data only\}}

Song F. Natural evolution and clinical management of cervical intraepithelial neoplasia during pregnancy and postpartum. Conference: 19th FIGO World Congress of Gynecology and Obstetrics Cape Town South Africa. International Journal of Gynecology and Obstetrics. 2009.

\section{Underwood 2013 \{published data only\}}

Underwood M. Thermo-coagulation for the treatment of cervical intraepithelial neoplasia: A successful alternative to cervical excision? Treatment success rates and obstetric outcomes. Conference: RCOG World Congress 2013 Liverpool United Kingdom. BJOG: An International Journal of Obstetrics and Gynaecology. 2013.

\section{Vasiliu 2010 \{published data only\}}

Vasiliu C. Cervical surgery and the risk of preterm birth. Conference: 22nd European Congress of Perinatal Medicine, 2010 Granada Spain. Journal of Maternal-Fetal and Neonatal Medicine. 2010.

\section{Additional references}

\section{Arbyn 2008}

Arbyn M, Kyrgiou M, Simoens C, Raifu AO, Koliopoulos G, MartinHirsch $P$, et al. Perinatal mortality and other severe adverse pregnancy outcomes associated with treatment of cervical intraepithelial neoplasia: meta-analysis. BMJ 2008;337:a1284.

\section{Arbyn 2009}

Arbyn M, Raifu AO, Bray F, Weiderpass E, Anttila A. Trends of cervical cancer mortality in the member states of the European Union. European Journal of Cancer 2009;45:2640-8.

\section{Arbyn 2012}

Arbyn M, Ronco G, Anttila A, Meijer CJ, Poljak M, Ogilvie G, et al. Evidence regarding human papillomavirus testing in secondary prevention of cervical cancer. Vaccine 2012;30(Supp 5):F88-99.

\section{Arbyn 2014}

Arbyn M, Kyrgiou M, Gondry J, Petry KU, Paraskevaidis E. Long term outcomes for women treated for cervical precancer. BMJ 2014;348:f7700.

\section{Begg 1994}

Begg CB, Mazumdar M. Operating characteristics of a rank correlation test for publication bias. Biometrics 1994;50(4):1088-101.

\section{Bruinsma 2007}

Bruinsma F, Lumley J, Tan J, Quinn M. Precancerous changes in the cervix and risk of subsequent preterm birth. British Journal of Obstetrics and Gynaecology 2007;114(1):70-80.

\section{Bruinsma 2011}

Bruinsma FJ, Quinn MA. The risk of preterm birth following treatment for precancerous changes in the cervix: a systematic review and meta-analysis. British Journal of Obstetrics and Gynaecology 2011;118(9):1031-41.

\section{Castanon 2012}

Castanon A, Brocklehurst P, Evans H, Peebles D, Singh N, Walker $P$, et al. Risk of preterm birth after treatment for cervica intraepithelial neoplasia among women attending colposcopy in England: retrospective-prospective cohort study. BMJ 2012;345:e5174.

\section{Castanon 2014b}

Castanon A, Landy R, Brocklehurst P, Evans H, Peebles D, Singh N, et al and the PaCT Study Group. Risk of preterm delivery with increasing depth of excision for cervical intraepithelial neoplasia in England: nested case-control study. BMJ 2014;349:g6223.

\section{Chew 1999}

Chew GK, Jandial L, Paraskevaidis E, Kitchener HC. Pattern of $\mathrm{CIN}$ recurrence following laser ablation treatment: longterm follow-up. International Journal of Gynecological Cancer 1999;9:487-90.

\section{Cochran 1954}

Cochran WG. The combination of estimates from different experiments. Biometrics 1954;10:101-29.

\section{Deeks 2001}

Deeks JJ, Altman DG, Bradburn MJ. Statistical methods for examining heterogeneity and combining results from several studies in meta-analysis. In: 2nd editor(s). Systematic Reviews in Health Care: Meta-Analysis in Context. London: BMJ Publication Group: In: Egger M, Davey Smith G, Altman DG (eds), 2001.

\section{Dersimonian 1986}

Dersimonian R, Laird NM. Meta-analysis in clinical trials. Controlled Clinical Trials 1986;7:177-88. 


\section{Egger 1997}

Egger M, Smith GD, Schneider M, Minder C. Bias in meta-analysis detected by a simple, graphical test. BMJ 1997;315:629-35.

\section{Ferlay 2013}

Ferlay J, Soerjomataram I, Ervik M, Dikshit R, Eser S, Mathers C, et al. GLOBOCAN 2012 v1.0, Cancer Incidence and Mortality Worldwide. IARC CancerBase No. 11 [Internet]. Lyon, France. International Agency for Research on Cancer. 2013. http:// globocan.iarc.fr.

\section{Founta 2010}

Founta C, Arbyn M, Valasoulis G, Kyrgiou M, Tsili A, MartinHirsch P, et al. Proportion of excision and cervical healing after large loop excision of the transformation zone for cervical intraepithelial neoplasia. British Journal of Obstetrics and Gynaecology 2010;117(12):468-74.

\section{GRADE Working Group 2004}

GRADE Working Group 2004 GRADE Working Group. Grading quality of evidence and strength of recommendations. BMJ 2004;7454:1490-4.

\section{Hammond 1990}

Hammond RH, Edmonds DK. Does treatment for cervical intraepithelial neoplasia affect fertility and pregnancy?. BMJ 1990;301(6765):344-5.

\section{Heinonen 2013}

Heinonen A, Gissler M, Riska A, Paavonen J, Tapper AM, Jakobsson M. Loop electrosurgical excision procedure and the risk for preterm delivery. Obstet Gynecol 2013;121(5):1063-8.

\section{Higgins 2003}

Higgins JP, Thompson SG, Deeks JJ, Altman DG. Measuring inconsistency in meta-analyses. BMJ 2003;327(7414):557-60.

\section{Higgins 2011}

Higgins JPT, Green S (editors). Cochrane Handbook of Systematic Reviews of Interventions Version 5.1.0 [updated March 2011]. The Cochrane Collaboration. Available from www.cochrane-handbook.org.

\section{Holmes 2012a}

Holmes E, Kinross J, Gibson GR, Burcelin R, Jia W, Pettersson S, et al. Therapeutic modulation of microbiota-host metabolic interactions. Science Translational Medicine 2012;4(137):rv6.

\section{Holmes 2012b}

Holmes E, Li JV, Marchesi JR, Nicholson JK. Gut microbiota composition and activity in relation to host metabolic phenotype and disease risk. Cell Metabolism 2012;16(5):559-64.

\section{Human Microbiome Project Consortium 2012}

Human Microbiome Project Consortium. Structure, function and diversity of the healthy human microbiome. Nature 2012;486(7402):207-14.

\section{Jakobsson 2007}

Jakobsson M, Gissler M, Sainio S, Paavonen J, Tapper AM. Preterm delivery after surgical treatment for cervical intraepithelial neoplasia. Obstetrics and Gynecology 2007;109(2 Pt 1):309-13.

\section{Jimenez 2013}

Jiménez B, Mirnezami R, Kinross J, Cloarec O, Keun HC, Holmes E, et al. 1H HR-MAS NMR spectroscopy of tumorinduced local metabolic "field-effects" enables colorectal cancer staging and prognostication. Journal of Proteome Research 2013;12(2):959-68.

\section{Kalliala 2012}

Kalliala I, Anttila A, Dyba T, Hakulinen T, Halttunen M, Nieminen P. Pregnancy incidence and outcome among patients with cervical intraepithelial neoplasia: a retrospective cohort study. British Journal of Obstetrics and Gynaecology 2012;119(2):227-35

\section{Kennedy 1993}

Kennedy S, Robinson J, Hallam N. LLETZ and infertility. British Journal of Obstetrics and Gynaecology 1993;100(10):965.

\section{Kitchener 1995}

Kitchener HC, Cruickshank ME, Farmery E. The 1993 British Society for Colposcopy and Cervical Pathology/National Coordinating Network United Kingdom Colposcopy Survey Comparison with 1988 and the response to introduction of guidelines. British Journal of Obstetrics and Gynaecology 1995;102:549-52.

\section{Kyrgiou 2006}

Kyrgiou M, Koliopoulos G, Martin-Hirsch P, Arbyn M, Prendiville W, Paraskevaidis E. Obstetric outcomes after conservative treatment for intraepithelial or early invasive cervical lesions: systematic review and meta-analysis. Lancet 2006;367(9509):489-98.

\section{Kyrgiou 2012}

Kyrgiou M, Arbyn M, Martin-Hirsch P, Paraskevaidis E. Increased risk of preterm birth after treatment for CIN. BMJ 2012;345:e5847.

\section{Kyrgiou 2015}

Kyrgiou M, Valasoulis G, Stasinou SM, Founta C, Athanasiou A, Bennett $P$, et al. Proportion of cervical excision for CIN as a predictor of pregnancy outcomes: a prospective study. International Journal of Gynecology and Obstetrics 2015;128(2):141-7.

\section{Li 2011}

Li JV, Ashrafian H, Bueter M, Kinross J, Sands C, le Roux CW, et al. Metabolic surgery profoundly influences gut microbial-host metabolic cross-talk. Gut 2011;60(9):1214-23.

\section{Martin-Hirsch 2013}

Martin-Hirsch PP, Paraskevaidis E, Bryant A, Dickinson HO. Surgery for cervical intraepithelial neoplasia. Cochrane Database of Systematic Reviews 2013, Issue 12. [DOI: 10.1002/14651858.CD001318.pub3] 


\section{Moher 2009}

Moher D, Liberati A, Tetzlaff J, Altman DG, PRISMA Group. Preferred reporting items for systematic review and meta-analyses: the PRISMA statement. Journal of Clinical Epidemiology 2009;62(10):1006-12.

\section{NHS Cervical Screening Programme 2010}

NHS Cervical Screening Programme. Document No 20. Colposocopy and Programme Management. 2010. Available from www.cancerscreening.nhs.uk/cervical/publications/ index.html.

\section{NHS Cervical Screening Programme 2012}

NHS Cervical Screening Programme. Annual Review. Available from http://www.cancerscreening.nhs.uk/cervical/ publications/2012review.html, 2012.

\section{Nicholson 2012}

Nicholson JK, Holmes E, Kinross J, Burcelin R, Gibson G, Jia W, et al. Host-gut microbiota metabolic interactions. Science 2012;336(6086):1262-7.

\section{Noehr 2009}

Noehr B, Jensen A, Frederiksen K, Tabor A, Kjaer SK. Depth of cervical cone removed by loop electrosurgical excision procedure and subsequent risk of spontaneous preterm delivery. Obstetrics \& Gynecology 2009;114(6):1232-8.

\section{Nuovo 2000}

Nuovo J, Melnikow J, Willan AR, Chan BK. Treatment outcomes for squamous intraepithelial lesions. International Journal of Gynaecology and Obstetrics 2000;68:25-33.

\section{Paraskevaidis 1991}

Paraskevaidis E, Jandial L, Mann EM, Fisher PM, Kitchener HC. Pattern of treatment failure following laser for cervical intraepithelial neoplasia: implications for follow-up protocol. Obstetrics and Gynecology 1991;78:80-3.

\section{Paraskevaidis 2007}

Paraskevaidis E, Kyrgiou M, Martin-Hirsch P. Have we dismissed ablative treatment too soon in colposcopy practice?. British Journal of Obstetrics and Gynaecology 2007;114(1):3-4.

\section{Phadnis 2011}

Phadnis SV, Atilade A, Bowring J, Kyrgiou M, Young MP, Evans $\mathrm{H}$, et al. Regeneration of cervix after excisional treatment for cervical intraepithelial neoplasia: a study of collagen distribution. British Journal of Obstetrics and Gynaecology 2011;118(13):1585-91.

\section{Phillipp 2003}

Philipp T, Philipp K, Reiner A, Beer F, Kalousek DK. Embryoscopic and cytogenetic analysis of 233 missed abortions: factors involved in the pathogenesis of developmental defects of early failed pregnancies. Human Reproduction 2003;18:1724-32.

\section{Prendiville 1989}

Prendiville W, Cullimore J, Norman S. Large loop excision of the transformation zone (LLETZ). A new method of management for women with cervical intraepithelial neoplasia. British Journal of Obstetrics and Gynaecology 1989;96(9):1054-60.

\section{Quinn 1999}

Quinn M, Babb P, Jones J, Allen E. Effect of screening on incidence of and mortality from cancer of cervix in England: evaluation based on routinely collected statistics. BMJ 1999;318(7188):904-8.

\section{Ravel 2011}

Ravel J, Gajer P, Abdo Z, Schneider GM, Koenig SS, McCulle SL, et al. Vaginal microbiome of reproductive-age women. Proceedings of the National Academy of Sciences of the United States of America 2011;108(Suppl 1):4680-7.

\section{Soutter 1997}

Soutter WP, de Barros Lopes A, Fletcher A, Monaghan JM, Duncan ID, Paraskevaidis E, et al. Invasive cervical cancer after conservative therapy for CIN. Lancet 1997;349:978-80.

\section{Steichen 1998}

Steichen TJ. Tests for publication bias in meta-analysis. Stata Technical Bulletin 1998;7:125-33.

\section{Strander 2014}

Strander B, Hällgren J, Sparén P. Effect of ageing on cervical or vaginal cancer in Swedish women previously treated for cervical intraepithelial neoplasia grade 3: population based cohort study of long term incidence and mortality. BMJ 2014;348:f7361.

\section{Stroup 2000}

Stroup DF, Berlin JA, Morton SC, Olkin I, Williamson GD, Rennie D, et al. Meta-analysis of observational studies in epidemiology: a proposal for reporting. Meta-analysis of Observational Studies in Epidemiology (MOOSE) group. JAMA 2000;283:2008-12.

\section{Suarez 2006}

Suarez S, Pacey A. Sperm transport in the female reproductive tract. Human Reprod Update 2006;12:23-37.

\section{Wells 2010}

Wells GA, Shea B, O'Connell D, Peterson J, Welch V, Losos M, et al. The Newcastle-Ottawa Scale (NOS) for assessing the quality of nonrandomised studies in meta-analyses. 2010. www.ohri.ca/ programs/clinical_epidemiology/nos_manual.pdf..

\section{References to other published versions of this review}

Kyrgiou 2010

Kyrgiou M, Arbyn M, Koliopoulos G, Martin-Hirsch PPL, Alamanos YP, Prendiville WJ, at al. Obstetric outcomes and fertility after conservative treatment for cervical intraepithelial lesions. Cochrane Database of Systematic Reviews 2010, Issue 4. [DOI: 10.1002/14651858.CD008478]

\section{Kyrgiou 2014}

Kyrgiou M, Mitra A, Arbyn M, Stasinou SM, Martin-Hirsch P, Bennett $P$, et al. Fertility and early pregnancy outcomes after 
treatment for cervical intraepithelial neoplasia: systematic review and meta-analysis. BMJ 2014 Oct;349:g6192.

\section{CHARACTERISTICS OF STUDIES}

\section{Characteristics of included studies [ordered by study ID]}

Albrechtsen 2008

Rethods
Comparison group: external - unmatched, regression analysis for age and birth order
Information source - Cancer Registry of Norway and the National Birth Registry of Norway
Control group identified from National Birth Registry of Norway

Control group identified from National Birth Registry of Norway

Treated group - 15,108 women who had undergone cervical treatment between 1967-2003 and had a
subsequent pregnancy
Control group - 2,164,006 women with no history of cervical treatment who had a pregnancy

\begin{tabular}{ll}
\hline Interventions & Excision NOS (CKC, LC, LLETZ) \\
\hline Outcomes & Early pregnancy outcome - 2nd trimester miscarriage
\end{tabular}

Notes

\begin{tabular}{|c|c|c|}
\hline \multicolumn{3}{|l|}{ Risk of bias } \\
\hline Bias & Authors' judgement & Support for judgement \\
\hline $\begin{array}{l}\text { Incomplete outcome data } \\
\text { (attrition bias) } \\
\text { All outcomes }\end{array}$ & Low risk & Data obtained from national registry \\
\hline $\begin{array}{l}\text { Selective reporting (re- } \\
\text { porting bias) }\end{array}$ & Low risk & No obvious reporting bias \\
\hline Other bias & Unclear risk & $\begin{array}{l}\text { During 1980-1985 the Cancer registry included only the grade of CIN and did } \\
\text { not include the treatment. The researchers excluded those women from the } \\
\text { treated group and included them in the untreated group, even though they } \\
\text { might have had treatment. Given the large population of this study, it is not ex- } \\
\text { pected that this potential misclassification bias has affected the results of the } \\
\text { study to a significant extent. }\end{array}$ \\
\hline $\begin{array}{l}\text { Relevant assignment de- } \\
\text { scribed? }\end{array}$ & Low risk & Yes, treatment performed on clinical grounds \\
\hline $\begin{array}{l}\text { Representative interven- } \\
\text { tion group? }\end{array}$ & Low risk & $\begin{array}{l}\text { All patients who gave birth between } 1967-2003 \text { and had a previous cervical } \\
\text { conisation were included. }\end{array}$ \\
\hline $\begin{array}{l}\text { Representative compari- } \\
\text { son group? }\end{array}$ & Low risk & $\begin{array}{l}\text { All patients who gave birth between } 1967-2003 \text { and did not have previous cer- } \\
\text { vical conisation were included. Patient information was obtained from the } \\
\text { same national registry. }\end{array}$ \\
\hline $\begin{array}{l}\text { Comparability of treat- } \\
\text { ment groups? }\end{array}$ & Low risk & Regression analysis was performed for age and birth order. \\
\hline
\end{tabular}




\section{Bigrigg 1994}

\begin{tabular}{ll} 
Methods & Retrospective cohort study \\
& Comparison group: external - matching for age, geographic location, all controls had negative smears \\
& Information source - questionnaires through telephone interview \\
& Control group identified from Family Health Services Authorities cervical smear database. \\
\hline Participants & Treated group - 76 to $229^{*}$ women who had undergone cervical treatment \\
& Control group - 66 to $229^{*}$ women with no history of cervical treatment and a negative cervical smear \\
& *Ranges represent different number of cases and controls for every outcome in the same study \\
\hline Interventions & LLETZ \\
\hline Outcomes & Fertility outcomes - total pregnancy rate; conception rates within given time periods \\
\hline Notes & Early pregnancy complications - total miscarriages rates; ectopic pregnancy rates
\end{tabular}

\section{Risk of bias}

\begin{tabular}{lll}
\hline Bias & Authors' judgement & Support for judgement \\
\hline $\begin{array}{l}\text { Incomplete outcome data } \\
\text { (attrition bias) } \\
\text { All outcomes }\end{array}$ & High risk & Only a proportion of the patients answered the questionnaire (24.2\%). \\
\hline $\begin{array}{l}\text { Selective reporting (re- } \\
\text { porting bias) }\end{array}$ & Low risk & No obvious reporting bias \\
\hline $\begin{array}{l}\text { Other bias } \\
\text { Relevant assignment de- } \\
\text { scribed? }\end{array}$ & Low risk & Potential recall or misclassification bias \\
\hline $\begin{array}{l}\text { Representative interven- } \\
\text { tion group? }\end{array}$ & High risk & Yes, treatment performed on clinical grounds \\
\hline $\begin{array}{l}\text { Representative compari- } \\
\text { son group? }\end{array}$ & Low risk & $\begin{array}{l}\text { Only a proportion of the patients answered the questionnaire so this may not } \\
\text { be a representative group. }\end{array}$ \\
\hline $\begin{array}{l}\text { Comparability of treat- } \\
\text { ment groups? }\end{array}$ & Low risk & Drawn from the same source as the treated group \\
\hline
\end{tabular}

\section{Blomfield 1993}

Retrospective cohort study
Comparison group: external - matching for age, parity, ethnicity
Information source - hospital records, 1989-1992
Control group identified and matched from women delivered immediately before or after index cases


Blomfield 1993 (Continued)

Participants

Treated group - 40 women who had undergone cervical treatment and had a subsequent pregnancy

Control group - 80 women with no history of cervical treatment who had a pregnancy

\begin{tabular}{ll}
\hline Interventions & LLETZ \\
\hline Outcomes & Early pregnancy complications - 2nd trimester miscarriages \\
\hline Notes & \\
\hline
\end{tabular}

\section{Risk of bias}

\begin{tabular}{lll}
\hline Bias & Authors' judgement & Support for judgement \\
\hline $\begin{array}{l}\text { Incomplete outcome data } \\
\text { (attrition bias) } \\
\text { All outcomes }\end{array}$ & Low risk & Information obtained from hospital records \\
\hline $\begin{array}{l}\text { Selective reporting (re- } \\
\text { porting bias) }\end{array}$ & Low risk & No obvious reporting bias \\
\hline $\begin{array}{l}\text { Other bias } \\
\text { Relevant assignment de- } \\
\text { scribed? }\end{array}$ & Low risk & No other source of bias identified \\
\hline $\begin{array}{l}\text { Representative interven- } \\
\text { tion group? }\end{array}$ & Low risk & Yes, treatment performed on clinical grounds \\
\hline $\begin{array}{l}\text { Representative compari- } \\
\text { son group? }\end{array}$ & Low risk & $\begin{array}{l}\text { All women who were eligible for the study who had LLETZ at Dudley Road Hos- } \\
\text { pital between January 1982 and January 1992. However, more than 60\% of the } \\
\text { women delivering at Dudley Road Hospital are nonwhite. }\end{array}$ \\
\hline $\begin{array}{l}\text { Comparability of treat- } \\
\text { ment groups? }\end{array}$ & Low risk & $\begin{array}{l}\text { Control group matched from women delivered immediately before or after in- } \\
\text { dex cases }\end{array}$ \\
\hline
\end{tabular}

Buller 1982

\begin{tabular}{ll}
\hline Methods & Retrospective cohort study \\
& Comparison group: internal (self-matching) \\
& Information source - hospital records \\
\hline Participants & $\begin{array}{l}\text { Treated group - } 88 \text { women who had undergone cervical treatment under the age of } 39 \text { years and had a } \\
\text { subsequent pregnancy } \\
\text { Control group - } 106 \text { treated women who had a pregnancy prior to their cervical treatment }\end{array}$ \\
\hline Interventions & CKC \\
\hline Outcomes & $\begin{array}{l}\text { Early pregnancy complications - total, 1st and 2nd trimester miscarriage rates; ectopic pregnancy rates; } \\
\text { molar pregnancy rates; termination of pregnancy rates }\end{array}$
\end{tabular}

Notes 
Buller 1982 (Continued)

\section{Risk of bias}

\begin{tabular}{lll}
\hline Bias & Authors' judgement & Support for judgement \\
\hline $\begin{array}{l}\text { Incomplete outcome data } \\
\text { (attrition bias) } \\
\text { All outcomes }\end{array}$ & High risk & $\begin{array}{l}227 \text { women were eligible for the study. Of these, 61 (26.9\%) were lost to fol- } \\
\text { low-up. }\end{array}$ \\
\hline $\begin{array}{l}\text { Selective reporting (re- } \\
\text { porting bias) }\end{array}$ & Low risk & No obvious reporting bias \\
\hline $\begin{array}{l}\text { Other bias } \\
\text { Relevant assignment de- } \\
\text { scribed? }\end{array}$ & Low risk & No other source of bias identified \\
\hline $\begin{array}{l}\text { Representative interven- } \\
\text { tion group? }\end{array}$ & Low risk & Yes, treatment performed on clinical grounds \\
\hline $\begin{array}{l}\text { Representative compari- } \\
\text { son group? }\end{array}$ & Low risk & $\begin{array}{l}\text { All women who were eligible for the study who had CKC in two hospitals be- } \\
\text { tween 1968-1978 }\end{array}$ \\
\hline $\begin{array}{l}\text { Comparability of treat- } \\
\text { ment groups? }\end{array}$ & Low risk & Internal matching to provide control group \\
\hline
\end{tabular}

\section{Cruickshank 1995}

\begin{tabular}{ll}
\hline Methods & Retrospective cohort study \\
& $\begin{array}{l}\text { Comparison group: external - matching for maternal age, parity, height, smoking and partner's social } \\
\text { class } \\
\text { Information source - postal questionnaires and the Aberdeen Maternity and Neonatal Databank } \\
(1989-1991)\end{array}$ \\
\hline Participants & Treated group - 149 women who had undergone previous LLETZ. \\
& $\begin{array}{l}\text { Control group - } 298 \text { women with no history of cervical treatment, identified from Aberdeen Maternity } \\
\text { and Neonatal Databank }\end{array}$ \\
\hline Interventions & LLETZ \\
\hline Outcomes & Early pregnancy complications - miscarriages (2nd trimester) \\
\hline Notes & $\begin{array}{l}\text { The study included } 1000 \text { women who had undergone previous LLETZ between } 1989 \text { and } 1991.653 \\
\text { treated women responded to a postal questionnaire, of which } 149 \text { had a subsequent singleton preg- } \\
\text { nancy and were included in the analysis. Two controls were matched for each treated case. }\end{array}$ \\
\hline
\end{tabular}

\section{Risk of bias}

\begin{tabular}{lll}
\hline Bias & Authors' judgement & Support for judgement \\
\hline $\begin{array}{l}\text { Incomplete outcome data } \\
\text { (attrition bias) } \\
\text { All outcomes }\end{array}$ & High risk & $\begin{array}{l}\text { Only a proportion of the patients who were contacted by post responded } \\
(34.7 \%) .\end{array}$
\end{tabular}


Cruickshank 1995 (Continued)

\begin{tabular}{lll}
$\begin{array}{l}\text { Selective reporting (re- } \\
\text { porting bias) }\end{array}$ & Low risk & No obvious reporting bias \\
\hline Other bias & High risk & Potential recall or misclassification bias \\
\hline $\begin{array}{l}\text { Relevant assignment de- } \\
\text { scribed? }\end{array}$ & Low risk & Yes, treatment performed on clinical grounds \\
\hline $\begin{array}{l}\text { Representative interven- } \\
\text { tion group? }\end{array}$ & High risk & Only a proportion of the patients who were contacted by post responded. \\
\hline $\begin{array}{l}\text { Representative compari- } \\
\text { son group? }\end{array}$ & Low risk & Drawn from the same source as the treated group \\
\hline $\begin{array}{l}\text { Comparability of treat- } \\
\text { ment groups? }\end{array}$ & Low risk & Matching for maternal age, parity, height, smoking and partner's social class \\
\hline
\end{tabular}

\section{Frega 2013}

\begin{tabular}{ll} 
Methods & $\begin{array}{l}\text { Prospective cohort study } \\
\text { Comparison group: external - controls had similar age, ethnicity, they were all nulliparous and all had } \\
\text { spontaneous pregnancies } \\
\text { Information source - prospective follow-up 2003-2007 }\end{array}$ \\
\hline Participants & $\begin{array}{l}\text { Treated group - } 1329 \text { women who had undergone LLETZ } \\
\text { Control group - } 462 \text { pregnant women with no history of cervical treatment, identified from general gy- } \\
\text { naecology out-patient clinics in the same hospital }\end{array}$ \\
\hline Interventions & LLETZ \\
\hline Outcomes & $\begin{array}{l}\text { Early pregnancy complications - total miscarriages rates } \\
\text { Notes }\end{array}$ \\
\hline 462 untreated controls were enrolled, of whom 21 were lost to follow-up.
\end{tabular}

\section{Risk of bias}

\begin{tabular}{lll}
\hline Bias & Authors' judgement & Support for judgement \\
\hline $\begin{array}{l}\text { Incomplete outcome data } \\
\text { (attrition bias) } \\
\text { All outcomes }\end{array}$ & Low risk & The number of women lost to follow-up was low (3.7\%). \\
\hline $\begin{array}{l}\text { Selective reporting (re- } \\
\text { porting bias) }\end{array}$ & Low risk & No obvious reporting bias \\
\hline $\begin{array}{l}\text { Other bias } \\
\text { Relevant assignment de- }\end{array}$ & Low risk & No other source of bias identified \\
\hline scribed? & Yes, treatment performed on clinical grounds \\
\hline
\end{tabular}


Frega 2013 (Continued)

\begin{tabular}{|c|c|c|}
\hline $\begin{array}{l}\text { Representative interven- } \\
\text { tion group? }\end{array}$ & Low risk & $\begin{array}{l}\text { All patients who had a cervical conisation from 2003-2007 who met the inclu- } \\
\text { sion and exclusion criteria were included. }\end{array}$ \\
\hline
\end{tabular}
tion group? sion and exclusion criteria were included.

Representative compari- Low risk

Control group were non-pregnant women referred to the general gynaecology son group? out-patient clinics in the same hospital.

\begin{tabular}{ll}
\hline $\begin{array}{l}\text { Comparability of treat- } \\
\text { ment groups? }\end{array}$ & Low risk \\
& $\begin{array}{l}\text { Each cervical treatment was performed by the same surgeon. Controls were } \\
\text { unmatched. }\end{array}$
\end{tabular}

Kallialla 2012

\begin{tabular}{ll}
\hline Methods & Retrospective cohort study \\
& Comparison group: external - unmatched with regression analysis for number of pregnancies and chil- \\
dren, age, municipality & \\
Information source - hospital records (1974-2001); National registers: Finnish Population Register (to \\
identify controls), THL, Care Registers for Social Welfare and Health Care (pregnancy outcomes)
\end{tabular}

\begin{tabular}{ll}
\hline Participants & Treated group - 6179 women who had undergone cervical treatment \\
& Control group - 30,436 women with no history of cervical treatment \\
& Five control women were matched to every treated woman. \\
\hline Interventions & Treatment NOS (CKC, LC, LLETZ, LA, CT) \\
\hline Outcomes & Fertility outcomes - total pregnancy rates \\
\hline Notes & $\begin{array}{l}\text { CKC was used from } 1974 \text { to 1978, CT was used from } 1978 \text { to 1988, LC or LA was used from 1979 to 1991, } \\
\text { and LLETZ has been used from 1991 onwards }\end{array}$ \\
\hline
\end{tabular}

\section{Risk of bias}

\begin{tabular}{|c|c|c|}
\hline Bias & Authors' judgement & Support for judgement \\
\hline $\begin{array}{l}\text { Incomplete outcome data } \\
\text { (attrition bias) } \\
\text { All outcomes }\end{array}$ & Low risk & Use of a national registry \\
\hline $\begin{array}{l}\text { Selective reporting (re- } \\
\text { porting bias) }\end{array}$ & Low risk & No obvious reporting bias \\
\hline Other bias & Low risk & No other source of bias identified \\
\hline $\begin{array}{l}\text { Relevant assignment de- } \\
\text { scribed? }\end{array}$ & Low risk & Yes, treatment performed on clinical grounds \\
\hline $\begin{array}{l}\text { Representative interven- } \\
\text { tion group? }\end{array}$ & Low risk & All patients who had a cervical conisation from 1974-2001 were included. \\
\hline $\begin{array}{l}\text { Representative compari- } \\
\text { son group? }\end{array}$ & Low risk & $\begin{array}{l}\text { Control group were non-pregnant women identified from the Finnish Popula- } \\
\text { tion Register. }\end{array}$ \\
\hline $\begin{array}{l}\text { Comparability of treat- } \\
\text { ment groups? }\end{array}$ & Low risk & Regression analysis for number of pregnancies and children, age, municipality \\
\hline
\end{tabular}


Larsson 1982

Methods

Retrospective cohort study

Comparison group: internal (self-matching), comparable for age, parity, socioeconomic status, smok-

ing, surgical interventions, various disease

Information source - South Swedish Regional Tumour Registry, hospital records

\begin{tabular}{ll}
\hline Participants & Treated group - 294 women who had undergone cervical treatment \\
Control group - 341 treated women prior to their cervical treatment
\end{tabular}

\begin{tabular}{ll}
\hline Interventions & CKC \\
\hline Outcomes & $\begin{array}{l}\text { Early pregnancy outcomes - total, 1st and 2nd trimester miscarriages rates; ectopic pregnancy rates; } \\
\text { termination of pregnancy rates }\end{array}$
\end{tabular}

Notes

\section{Risk of bias}

\begin{tabular}{|c|c|c|}
\hline Bias & Authors' judgement & Support for judgement \\
\hline $\begin{array}{l}\text { Incomplete outcome data } \\
\text { (attrition bias) } \\
\text { All outcomes }\end{array}$ & Low risk & Use of hospital records \\
\hline $\begin{array}{l}\text { Selective reporting (re- } \\
\text { porting bias) }\end{array}$ & Low risk & No obvious reporting bias \\
\hline Other bias & Low risk & No other source of bias identified \\
\hline $\begin{array}{l}\text { Relevant assignment de- } \\
\text { scribed? }\end{array}$ & Low risk & Yes, treatment performed on clinical grounds \\
\hline $\begin{array}{l}\text { Representative interven- } \\
\text { tion group? }\end{array}$ & Low risk & $\begin{array}{l}\text { The treated group was pooled from the South Swedish Regional Tumour Reg- } \\
\text { istry. }\end{array}$ \\
\hline $\begin{array}{l}\text { Representative compari- } \\
\text { son group? }\end{array}$ & Low risk & Internal matching to provide control group \\
\hline $\begin{array}{l}\text { Comparability of treat- } \\
\text { ment groups? }\end{array}$ & Low risk & $\begin{array}{l}\text { Internal matching for age, parity, socioeconomic status, smoking, surgical in- } \\
\text { terventions, various diseases }\end{array}$ \\
\hline
\end{tabular}

Sagot 1995

\begin{tabular}{ll}
\hline Methods & Retrospective cohort study \\
& Comparison group: internal \\
Information source - hospital records $(1982-1992)$
\end{tabular}


Sagot 1995 (Continued)

Interventions
LC - before 1986, hand-held laser (10/54) under GA with 2 stitches, cone-shaped 1-2 cm deep, radius $1-1.5 \mathrm{~cm}$

LA for haemostasis - after 1986, micromanipulator (44/54), less radical, cylinder, 0.8-1.8 cm deep, radius $0.6-0.8 \mathrm{~cm}$

Outcomes

Early pregnancy complications - total, 1st and 2nd trimester miscarriage rates; ectopic pregnancy rates; molar pregnancy rates; termination of pregnancy rates

\section{Notes}

\section{Risk of bias}

\begin{tabular}{lll}
\hline Bias & Authors' judgement & Support for judgement \\
\hline $\begin{array}{l}\text { Incomplete outcome data } \\
\begin{array}{l}\text { (attrition bias) } \\
\text { All outcomes }\end{array}\end{array}$ & High risk & $\begin{array}{l}\text { Of the } 222 \text { women who underwent LC between 1 July 1982 and 30 June 1992, } \\
48(21.6 \%) \text { could not be contacted. }\end{array}$ \\
\hline $\begin{array}{l}\text { Selective reporting (re- } \\
\text { porting bias) }\end{array}$ & Low risk & No obvious reporting bias \\
\hline $\begin{array}{l}\text { Other bias } \\
\text { Relevant assignment de- }\end{array}$ & Low risk & No other source of bias identified \\
\hline $\begin{array}{l}\text { Reribed? } \\
\text { tion group? }\end{array}$ & Yes, treatment performed on clinical grounds \\
\hline $\begin{array}{l}\text { Representative compari- } \\
\text { son group? }\end{array}$ & Low risk & $\begin{array}{l}\text { All patients who had a cervical conisation from 1983-1992, were considered } \\
\text { fertile (under 39 years, no history of hysterectomy or female sterilization) and } \\
\text { had one or more pregnancies since treatment were contacted to participate. }\end{array}$ \\
\hline $\begin{array}{l}\text { Comparability of treat- } \\
\text { ment groups? }\end{array}$ & Low risk & \begin{tabular}{l} 
Internal matching to provide control group \\
\hline
\end{tabular} \\
\hline
\end{tabular}

\section{Sjoborg 2007}

\begin{tabular}{ll}
\hline Methods & Retrospective cohort study \\
& $\begin{array}{l}\text { Comparison group: external - matching for age, parity, plurality and regression analysis for smoking, } \\
\text { marital status and education } \\
\text { Information source - national registry with written patient consent (1990-1999) } \\
\text { Control group identified from National Birth Registry of Norway }\end{array}$ \\
\hline Participants & Treated group - 742 women who had undergone cervical treatment and had a subsequent pregnancy \\
& Control group - 742 women with no previous history of cervical treatment who had a pregnancy \\
\hline Interventions & LC, LLETZ \\
\hline Outcomes & Early pregnancy complications - 2nd trimester miscarriage rates \\
\hline
\end{tabular}


Sjoborg 2007 (Continued)

Notes

2393 treated women contacted via post, of which 742 responded to provide written consent to participate and were included

\section{Risk of bias}

\begin{tabular}{|c|c|c|}
\hline Bias & Authors' judgement & Support for judgement \\
\hline $\begin{array}{l}\text { Incomplete outcome data } \\
\text { (attrition bias) } \\
\text { All outcomes }\end{array}$ & High risk & $\begin{array}{l}\text { Only a proportion of the patients who were contacted by post responded } \\
(69 \%) \text {. }\end{array}$ \\
\hline $\begin{array}{l}\text { Selective reporting (re- } \\
\text { porting bias) }\end{array}$ & Low risk & No obvious reporting bias \\
\hline Other bias & Low risk & No other source of bias identified \\
\hline $\begin{array}{l}\text { Relevant assignment de- } \\
\text { scribed? }\end{array}$ & Low risk & Yes, treatment performed on clinical grounds \\
\hline $\begin{array}{l}\text { Representative interven- } \\
\text { tion group? }\end{array}$ & Unclear risk & $\begin{array}{l}\text { Because it is a multi-centre study, the treated group is probably representa- } \\
\text { tive. However, only a proportion of the patients that were contacted by post } \\
\text { responded. }\end{array}$ \\
\hline $\begin{array}{l}\text { Representative compari- } \\
\text { son group? }\end{array}$ & Low risk & Drawn from the same source \\
\hline $\begin{array}{l}\text { Comparability of treat- } \\
\text { ment groups? }\end{array}$ & Low risk & $\begin{array}{l}\text { Matching for age, parity, plurality and regression analysis for smoking, marital } \\
\text { status and education }\end{array}$ \\
\hline
\end{tabular}

\section{Spitzer 1995}

\begin{tabular}{ll} 
Methods & $\begin{array}{l}\text { Retrospective cohort study } \\
\text { Comparison group: internal (self-matching) matched for age and parity } \\
\text { Information source - hospital records and questionnaires (by mail, telephone or in person) }\end{array}$ \\
\hline Participants & $\begin{array}{l}\text { Treated group - } 433 \text { women who had undergone cervical treatment } \\
\text { Control group - } 433 \text { treated women prior to their cervical treatment }\end{array}$ \\
\hline Interventions & LC, LA \\
\hline Outcomes & $\begin{array}{l}\text { Fertility outcomes - total pregnancy rates } \\
\text { Early pregnancy complications - total miscarriage rates; ectopic pregnancy rates; termination of preg- } \\
\text { nancy rates }\end{array}$
\end{tabular}

\section{Notes}

\section{Risk of bias}

\begin{tabular}{lll}
\hline Bias & Authors' judgement & Support for judgement \\
\hline $\begin{array}{l}\text { Incomplete outcome data } \\
\text { (attrition bias) }\end{array}$ & High risk & Only $47.9 \%$ responded to the questionnaires \\
\hline
\end{tabular}


Spitzer 1995 (Continued)

All outcomes

\begin{tabular}{lll}
\hline $\begin{array}{l}\text { Selective reporting (re- } \\
\text { porting bias) }\end{array}$ & Low risk & No obvious reporting bias \\
\hline Other bias & High risk & Potential recall or misclassification bias \\
\hline $\begin{array}{l}\text { Relevant assignment de- } \\
\text { scribed? }\end{array}$ & Low risk & Yes, treatment performed on clinical grounds \\
\hline $\begin{array}{l}\text { Representative interven- } \\
\text { tion group? }\end{array}$ & High risk & Only a proportion of the patients responded to the questionnaires. \\
\hline $\begin{array}{l}\text { Representative compari- } \\
\text { son group? }\end{array}$ & Low risk & Internal matching to provide control group \\
\hline $\begin{array}{l}\text { Comparability of treat- } \\
\text { ment groups? }\end{array}$ & Low risk & Internal matching \\
\hline
\end{tabular}

\section{Spracklen 2013}

\begin{tabular}{ll}
\hline Methods & Retrospective cohort study \\
Comparison group: \\
\begin{tabular}{l} 
A) External - unmatched but includes regression analysis for age, education, household income, race, \\
parity, pre-pregnancy BMI, smoking, cervical surgery, case status \\
B) Women attending colposcopy but not treated \\
Information source - birth register, telephone interview \\
All potential case and control subjects were identified and selected from the lowa electronic birth cer- \\
tificate file. \\
\hline Preated group - 152 women who had undergone cervical treatment and had a subsequent pregnancy \\
Control groups - 1021 women with no history of cervical treatment or colposcopy who had a pregnan- \\
cy; 152 women who underwent colposcopy and had a subsequent pregnancy
\end{tabular} \\
\hline Interventions & Fertility outcomes - conception within a given period \\
\hline Outcomes &
\end{tabular}

\section{Risk of bias}

\begin{tabular}{|c|c|c|}
\hline Bias & Authors' judgement & Support for judgement \\
\hline $\begin{array}{l}\text { Incomplete outcome data } \\
\text { (attrition bias) } \\
\text { All outcomes }\end{array}$ & High risk & $\begin{array}{l}\text { Only a proportion of the women were reached by phone and then gave their } \\
\text { consent }(52.6 \%) \text {. }\end{array}$ \\
\hline $\begin{array}{l}\text { Selective reporting (re- } \\
\text { porting bias) }\end{array}$ & Low risk & No obvious reporting bias \\
\hline
\end{tabular}


Spracklen 2013 (Continued)

\begin{tabular}{lll} 
Other bias & High risk & Potential recall or misclassification bias \\
\hline $\begin{array}{l}\text { Relevant assignment de- } \\
\text { scribed? }\end{array}$ & Low risk & Yes, treatment performed on clinical grounds \\
\hline $\begin{array}{l}\text { Representative interven- } \\
\text { tion group? }\end{array}$ & Unclear risk & $\begin{array}{l}\text { Because this is a population-based study, the treated group is probably repre- } \\
\text { sentative. However, only a proportion of the women were reached by phone } \\
\text { and then gave their consent. }\end{array}$ \\
\hline $\begin{array}{l}\text { Representative compari- } \\
\text { son group? }\end{array}$ & Low risk & Drawn from the same source \\
\hline $\begin{array}{l}\text { Comparability of treat- } \\
\text { ment groups? }\end{array}$ & Low risk & $\begin{array}{l}\text { Regression analysis for age, education, household income, race, parity, pre- } \\
\text { pregnancy BMl, smoking, cervical surgery, case status }\end{array}$ \\
\hline
\end{tabular}

Tan 2004

$\begin{array}{ll}\text { Methods } & \text { Retrospective cohort study } \\ \text { Comparison group: external - matching for age, parity } \\ \text { Information source - hospital records for women under } 35 \text { years of age from 1995-1998 }\end{array}$

\begin{tabular}{ll}
\hline Participants & Treated group - 119 women under 35 years of age who had undergone cervical treatment \\
Control group - 119 women with no previous history of cervical treatment
\end{tabular}

\begin{tabular}{|c|c|c|}
\hline Interventions & \multicolumn{2}{|l|}{ LLETZ } \\
\hline Outcomes & \multicolumn{2}{|c|}{ Early pregnancy complications - total miscarriage rates } \\
\hline \multicolumn{3}{|l|}{ Notes } \\
\hline \multicolumn{3}{|l|}{ Risk of bias } \\
\hline Bias & Authors' judgement & Support for judgement \\
\hline $\begin{array}{l}\text { Incomplete outcome data } \\
\text { (attrition bias) } \\
\text { All outcomes }\end{array}$ & High risk & $\begin{array}{l}168 \text { women were eligible for the study. Of these, } 49(29.2 \%) \text { were excluded be- } \\
\text { cause their notes could not be retrieved, with no further details given by the } \\
\text { authors. }\end{array}$ \\
\hline $\begin{array}{l}\text { Selective reporting (re- } \\
\text { porting bias) }\end{array}$ & Low risk & No obvious reporting bias \\
\hline Other bias & Low risk & No other source of bias identified \\
\hline $\begin{array}{l}\text { Relevant assignment de- } \\
\text { scribed? }\end{array}$ & Low risk & Yes, treatment performed on clinical grounds \\
\hline $\begin{array}{l}\text { Representative interven- } \\
\text { tion group? }\end{array}$ & Low risk & $\begin{array}{l}\text { All patients who had a cervical conisation from 1995-1998, were under } 35 \text { years } \\
\text { of age and had hospital records available for review were included. }\end{array}$ \\
\hline $\begin{array}{l}\text { Representative compari- } \\
\text { son group? }\end{array}$ & Low risk & Drawn from the same source \\
\hline
\end{tabular}


Tan 2004 (Continued)

Comparability of treat- Low risk Matching for age and parity ment groups?

Turlington 1996

Methods Retrospective cohort study

Comparison group: women attending colposcopy with biopsy but no treatment

Information source - telephone interview, mail questionnaire

Control group identified in colposcopy clinics; all had colposcopy +/- punch biopsy

Participants Treated group - 54 women who had undergone cervical treatment

Control groups - 57 women seen in colposcopy clinic with no previous history of cervical treatment

\begin{tabular}{ll}
\hline Interventions & LLETZ \\
\hline Outcomes & Fertility outcomes - total pregnancy rates; pregnancy rates in women wishing to conceive \\
& Early pregnancy outcomes - total miscarriages rates; termination of pregnancy rates \\
\hline
\end{tabular}

Notes

\section{Risk of bias}

\begin{tabular}{|c|c|c|}
\hline Bias & Authors' judgement & Support for judgement \\
\hline $\begin{array}{l}\text { Incomplete outcome data } \\
\text { (attrition bias) } \\
\text { All outcomes }\end{array}$ & High risk & $\begin{array}{l}\text { Only a proportion of the patients responded to the postal questionnaire or } \\
\text { telephone interview (29.7\%). }\end{array}$ \\
\hline $\begin{array}{l}\text { Selective reporting (re- } \\
\text { porting bias) }\end{array}$ & Low risk & No obvious reporting bias \\
\hline Other bias & High risk & Potential recall or misclassification bias \\
\hline $\begin{array}{l}\text { Relevant assignment de- } \\
\text { scribed? }\end{array}$ & Low risk & Yes, treatment performed on clinical grounds \\
\hline $\begin{array}{l}\text { Representative interven- } \\
\text { tion group? }\end{array}$ & High risk & $\begin{array}{l}\text { Only a proportion of the patients responded to the postal questionnaire or } \\
\text { telephone interview. }\end{array}$ \\
\hline $\begin{array}{l}\text { Representative compari- } \\
\text { son group? }\end{array}$ & Low risk & Control population also recruited from colposcopy clinic \\
\hline $\begin{array}{l}\text { Comparability of treat- } \\
\text { ment groups? }\end{array}$ & Unclear risk & $\begin{array}{l}\text { No description of matching, although the comparison group was taken from } \\
\text { women who were seen in colposcopy and had biospy but no treatment. }\end{array}$ \\
\hline
\end{tabular}

Weber 1979

$\begin{array}{ll}\text { Methods } & \text { Retrospective cohort study } \\ & \text { Comparison group: partly external - matching for age, parity; partly internal (self-matching) }\end{array}$


Weber 1979 (Continued)

Information source - interview, postal questionnaire

Participants Treated group - 21 women who had undergone cervical treatment

Control groups - 20 women with no history of cervical treatment

\begin{tabular}{ll}
\hline Interventions & CKC \\
\hline Outcomes & Fertility outcomes - pregnancy rates in women wishing to conceive; conception rates within given time \\
& Early pregnancy outcomes - total, 1st and 2nd miscarriage rates; termination of pregnancy rates \\
\hline
\end{tabular}

Notes

\section{Risk of bias}

\begin{tabular}{|c|c|c|}
\hline Bias & Authors' judgement & Support for judgement \\
\hline $\begin{array}{l}\text { Incomplete outcome data } \\
\text { (attrition bias) } \\
\text { All outcomes }\end{array}$ & Unclear risk & $\begin{array}{l}\text { Data acquired from hospital records and interviews; at risk of incomplete out- } \\
\text { comes data }\end{array}$ \\
\hline $\begin{array}{l}\text { Selective reporting (re- } \\
\text { porting bias) }\end{array}$ & Unclear risk & No obvious reporting bias \\
\hline Other bias & High risk & Potential recall or misclassification bias \\
\hline $\begin{array}{l}\text { Relevant assignment de- } \\
\text { scribed? }\end{array}$ & Low risk & Yes, treatment performed on clinical grounds \\
\hline $\begin{array}{l}\text { Representative interven- } \\
\text { tion group? }\end{array}$ & Low risk & The treated group was pooled from the records of two hospitals \\
\hline $\begin{array}{l}\text { Representative compari- } \\
\text { son group? }\end{array}$ & Low risk & Same source as treated group \\
\hline $\begin{array}{l}\text { Comparability of treat- } \\
\text { ment groups? }\end{array}$ & Low risk & Matching for age, parity and partly self-matching \\
\hline
\end{tabular}

CKC: cold knife conisation

BMI: body mass index

$\mathrm{CT}$ : computerized tomography

$\mathrm{GA}$ : general anaesthetic

LA: laser ablation

LC: laser conisation

LLETZ: large loop excision of the transformation zone

NOS: not otherwise specified

THL: National Institute for Health and Welfare

Characteristics of excluded studies [ordered by study ID]

\begin{tabular}{ll}
\hline Study & Reason for exclusion \\
\hline Acharya 2004 & No untreated control group \\
\hline Anderson 1984 & No untreated control group \\
\hline
\end{tabular}




\begin{tabular}{|c|c|}
\hline Study & Reason for exclusion \\
\hline Armarnik 2011 & No untreated control group \\
\hline Berretta 2013 & No untreated control group \\
\hline Braet 1994 & No untreated control group \\
\hline Conner 2013 & No untreated control group \\
\hline Ferenczy 1995 & No untreated control group \\
\hline Forsmo 1996 & No untreated control group \\
\hline Gordon 1991 & No untreated control group \\
\hline Haffenden 1993 & No untreated control group \\
\hline Hagen 1993 & No untreated control group \\
\hline Jones 1979 & No untreated control group \\
\hline Keijser 1992 & No untreated control group \\
\hline Khalid 2012 & No untreated control group \\
\hline Kuoppala 1986 & No untreated control group \\
\hline Luesley 1985 & No untreated control group \\
\hline Macvicar 1968 & No untreated control group \\
\hline Mathevet 2003 & No untreated control group \\
\hline Mazouni 2005 & No untreated control group \\
\hline Michelin 2009 & No untreated control group \\
\hline Paraskevaidis 2002 & No untreated control group \\
\hline Raio 1997 & No untreated control group \\
\hline Shanbhag 2009 & Does not include early pregnancy complications \\
\hline van de Vijver 2010 & No untreated control group \\
\hline
\end{tabular}

Characteristics of studies awaiting assessment [ordered by study ID]

Castanon 2013

\begin{tabular}{ll}
\hline Methods & Cohort study with a nested case-control study \\
\hline Participants & Women with a histological sample taken at colposcopy between 1989 and 2011 \\
\hline Interventions & Unclear \\
\hline
\end{tabular}


Castanon 2013 (Continued)

\begin{tabular}{ll} 
Outcomes & Early pregnancy outcomes - 2nd trimester miscarriage \\
\hline Notes & Conference abstract
\end{tabular}

\section{Castanon 2014a}

\begin{tabular}{ll}
\hline Methods & Nested case-control study \\
\hline Participants & Women with a histological sample taken at colposcopy between 1989 and 2011 \\
\hline Interventions & Unclear \\
\hline Outcomes & Early pregnancy outcomes - 2nd trimester miscarriage \\
\hline Notes & Conference abstract \\
\hline
\end{tabular}

\section{Chatterjee 2014}

\begin{tabular}{ll}
\hline Methods & Retrospective cohort study \\
\hline Participants & $\begin{array}{l}\text { Women age }<49 \text { who underwent an excisional procedure for cervical dysplasia between } 2000 \text { and } \\
2010\end{array}$ \\
\hline Interventions & Excisional treatment \\
\hline Outcomes & Early pregnancy outcomes - 2nd trimester miscarriage \\
\hline Notes & Conference abstract \\
\hline
\end{tabular}

Gay 2009

\begin{tabular}{ll}
\hline Methods & Unclear \\
\hline Participants & Unclear \\
\hline Interventions & Unclear \\
\hline Outcomes & Unclear \\
\hline Notes & Conference abstract \\
\hline
\end{tabular}

\section{Hong 2014}

\begin{tabular}{ll}
\hline Methods & Retrospective cohort \\
\hline Participants & Women undergoing treatment for high grade CIN \\
\hline Interventions & Bovie electroknife conization and cold knife conization \\
\hline \hline
\end{tabular}


Hong 2014 (Continued)

Outcomes Early pregnancy outcomes - unclear

Notes Conference abstract

Hongo 2012

\begin{tabular}{ll}
\hline Methods & Retrospective cohort \\
\hline Participants & Women with history of laser conisation prior to pregnancy \\
\hline Interventions & Laser conisation \\
\hline Outcomes & Early pregnancy outcomes - miscarriage \\
\hline Notes & Conference abstract \\
\hline
\end{tabular}

Jolley 2010

\begin{tabular}{ll}
\hline Methods & Retrospective cohort study \\
\hline Participants & Women with history of previous cervical surgery \\
\hline Interventions & Cervical surgery NOS \\
\hline Outcomes & Early pregnancy outcomes - unclear \\
\hline Notes & Conference abstract \\
\hline
\end{tabular}

Khan 2014

\begin{tabular}{ll}
\hline Methods & Prospective cohort study \\
\hline Participants & Women undergoing cone biopsy from January 2008 to December 2010 \\
\hline Interventions & Conisation NOS \\
\hline Outcomes & Fertility outcomes - pregnancy rates \\
& Early pregnancy outcomes - miscarriage, 2nd trimester miscarriage \\
\hline Notes & Conference abstract \\
\hline
\end{tabular}

Kundu 2014

\begin{tabular}{ll}
\hline Methods & Retrospective cohort study \\
\hline Participants & $\begin{array}{l}252 \text { patients, who had undergone LLETZ previously and delivered in Galway University Hospital be- } \\
\text { tween January } 2010 \text { and December } 2012\end{array}$ \\
\hline
\end{tabular}


Kundu 2014 (Continued)
Interventions
LLETZ

Outcomes Early pregnancy outcomes - miscarriage, 2nd trimester miscarriage

Notes Conference abstract

\section{Kyrgiou 2013}

\begin{tabular}{ll}
\hline Methods & Prospective observational study \\
\hline Participants & Women planned to undergo excisional treatment for CIN who wish to have future pregnancies \\
\hline Interventions & Excisional treatment NOS \\
\hline Outcomes & Fertility outcomes - pregnancy rates \\
& Early pregnancy outcomes - miscarriage, 1st trimester miscarriage, 2nd trimester miscarriage \\
\hline Notes & Conference abstract \\
\hline
\end{tabular}

\section{Kyrgiou 2013b}

\begin{tabular}{ll}
\hline Methods & Retrospective cohort \\
\hline Participants & Pregnant women who had excisional treatment prior to their first pregnancy \\
\hline Interventions & Excisional treatment NOS \\
\hline Outcomes & Early pregnancy outcomes - miscarriage, 1st trimester miscarriage, 2nd trimester miscarriage \\
\hline Notes & Conference abstract \\
\hline
\end{tabular}

\section{Kyrgiou 2014}

\begin{tabular}{ll}
\hline Methods & Prospective observational feasibility study \\
\hline Participants & Women (21-45 years old) planned for excisional CIN treatment. \\
\hline Interventions & Excisional treatment NOS \\
\hline Outcomes & Fertility outcomes - pregnancy rates \\
& Early pregnancy outcomes - miscarriage, 1st trimester miscarriage, 2nd trimester miscarriage \\
\hline Notes & Conference abstract \\
\hline
\end{tabular}


Liu 2009

\begin{tabular}{ll}
\hline Methods & Prospective cohort study \\
\hline Participants & 269 patients with CIN grade II-III who wanted to conceive \\
\hline Interventions & LEEP or CKC \\
\hline Outcomes & Fertility outcomes - pregnancy rates \\
& Early pregnancy outcomes - miscarriage, 1st trimester miscarriage, 2nd trimester miscarriage \\
\hline Notes & Conference abstract \\
\hline
\end{tabular}

McGee 2012

\begin{tabular}{ll}
\hline Methods & Retrospective cohort study \\
\hline Participants & $\begin{array}{l}\text { Women with one or more deliveries following exposure to CEP was compared to women referred to } \\
\text { colposcopy with a cytologic abnormality not exposed to a CEP }\end{array}$ \\
\hline Interventions & Cervical excisional procedures - CKC, LEEP, CT, LC, LA \\
\hline Outcomes & Unclear - 'adverse obstetric outcomes' \\
\hline Notes & Conference abstract \\
\hline
\end{tabular}

Mozo De Rosales 2009

\begin{tabular}{ll}
\hline Methods & Retrospective cohort study \\
\hline Participants & Women with a history of conisation \\
\hline Interventions & Conisation NOS \\
\hline Outcomes & Early pregnancy outcomes - unclear \\
\hline Notes & Conference abstract \\
\hline
\end{tabular}

Nehls 2010

\begin{tabular}{ll}
\hline Methods & Retrospective cohort study \\
\hline Participants & Women with a history of conisation \\
\hline Interventions & Conisation NOS \\
\hline Outcomes & Early pregnancy outcomes - unclear \\
\hline Notes & Conference abstract \\
\hline
\end{tabular}


Papoutsis 2013

\begin{tabular}{ll}
\hline Methods & Retrospective cohort \\
\hline Participants & $\begin{array}{l}\text { Women having had single and repeat LLETZ conisation for CIN pathology were identified from the } \\
\text { colposcopy database during a 14 year period (1998-2012). }\end{array}$ \\
\hline Interventions & LLETZ \\
\hline Outcomes & Early pregnancy outcomes - unclear \\
\hline Notes & Conference abstract \\
\hline
\end{tabular}

\section{Peebles 2013}

\begin{tabular}{ll}
\hline Methods & Record linkage study \\
\hline Participants & Women with cervical histology between 1987 and 2009 \\
\hline Interventions & Unclear \\
\hline Outcomes & Early pregnancy outcomes - miscarriages \\
\hline Notes & Conference abstract \\
\hline
\end{tabular}

Pinborg 2014

\begin{tabular}{ll}
\hline Methods & National controlled cohort study \\
\hline Participants & Women with history of conisation \\
\hline Interventions & Conisation NOS \\
\hline Outcomes & Early pregnancy outcomes - miscarriage, 2nd trimester miscarriage \\
\hline Notes & Conference abstract \\
\hline
\end{tabular}

Ruengkhachorn 2013

\begin{tabular}{ll}
\hline Methods & Retrospective cohort study \\
\hline Participants & Women who underwent LEEP during 6-year period in Siriraj Hospital, Mahidol University, Thailand \\
\hline Interventions & LEEP \\
\hline Outcomes & Ferility outcomes - unclear \\
& Early pregnancy outcomes - unclear \\
\hline Notes & Conference abstract \\
\hline
\end{tabular}


Smrkolj 2009

\begin{tabular}{ll}
\hline Methods & Retrospective cohort study \\
\hline Participants & Women with a history of conisation \\
\hline Interventions & Conisation NOS \\
\hline Outcomes & Early pregnancy outcomes - unclear \\
\hline Notes & Conference abstract \\
\hline
\end{tabular}

\section{Song 2009}

\begin{tabular}{ll}
\hline Methods & Prospective cohort study \\
\hline Participants & Women with CIN \\
\hline Interventions & Unclear \\
\hline Outcomes & Ferility outcomes - unclear \\
& Early pregnancy outcomes - unclear \\
\hline Notes & Conference abstract \\
\hline
\end{tabular}

Underwood 2013

\begin{tabular}{ll}
\hline Methods & Retrospective cohort study \\
\hline Participants & $\begin{array}{l}\text { All patients }(\mathrm{n}=614) \text { undergoing cold coagulation at the Shrewsbury and Telford National Health } \\
\text { Services Trust during the period of } 2000-2012\end{array}$ \\
\hline Interventions & Cold coagulation \\
\hline Outcomes & Early pregnancy outcomes - unclear \\
\hline Notes & Conference abstract \\
\hline
\end{tabular}

Vasiliu 2010

\begin{tabular}{ll}
\hline Methods & Retrospective cohort study \\
\hline Participants & Women undergoing LEEP \\
\hline Interventions & LEEP \\
\hline Outcomes & Early pregnancy outcomes - unclear \\
\hline Notes & Conference abstract \\
\hline
\end{tabular}


CEP: cervical excision procedure

$\mathrm{CIN}$ : cervical intraepithelial neoplasia

CKC: cold knife conisation

LEEP: loop electrosurgical excisional procedure

LLETZ: large loop excision of the transformation zone

NOS: not otherwise specified

Unclear: authors were unable to ascertain whether relevant outcomes were presented from conference abstract

\section{DATA AND ANALYSES}

\section{Comparison 1. Fertility outcomes}

\begin{tabular}{|c|c|c|c|c|}
\hline Outcome or subgroup title & No. of studies & $\begin{array}{l}\text { No. of partici- } \\
\text { pants }\end{array}$ & Statistical method & Effect size \\
\hline 1 Total pregnancy rates & 4 & 38050 & $\begin{array}{l}\text { Risk Ratio (IV, Random, 95\% } \\
\text { Cl) }\end{array}$ & $1.29[1.02,1.64]$ \\
\hline 1.1 LEEP/LLETZ versus no treatment & 2 & 569 & $\begin{array}{l}\text { Risk Ratio (IV, Random, 95\% } \\
\mathrm{Cl} \text { ) }\end{array}$ & $1.00[0.67,1.48]$ \\
\hline $\begin{array}{l}\text { 1.2 Laser conisation versus no treat- } \\
\text { ment }\end{array}$ & 1 & 200 & $\begin{array}{l}\text { Risk Ratio (IV, Random, 95\% } \\
\mathrm{Cl} \text { ) }\end{array}$ & $2.39[1.70,3.37]$ \\
\hline 1.3 Laser ablation versus no treatment & 1 & 666 & $\begin{array}{l}\text { Risk Ratio (IV, Random, 95\% } \\
\mathrm{CI})\end{array}$ & $1.41[1.22,1.63]$ \\
\hline $\begin{array}{l}1.4 \text { Treatment not specified versus no } \\
\text { treatment }\end{array}$ & 1 & 36615 & $\begin{array}{l}\text { Risk Ratio (IV, Random, 95\% } \\
\mathrm{CI} \text { ) }\end{array}$ & $1.09[1.06,1.13]$ \\
\hline $\begin{array}{l}2 \text { Pregnancy rate in women with inten- } \\
\text { tion to conceive }\end{array}$ & 2 & 70 & $\begin{array}{l}\text { Risk Ratio (IV, Random, 95\% } \\
\mathrm{Cl} \text { ) }\end{array}$ & $0.93[0.80,1.08]$ \\
\hline $\begin{array}{l}3 \text { Conception within } 0-3 \text { months (exci- } \\
\text { sional treatment versus no treatment) }\end{array}$ & 2 & 175 & $\begin{array}{l}\text { Risk Ratio (IV, Random, 95\% } \\
\text { Cl) }\end{array}$ & $0.89[0.67,1.19]$ \\
\hline $\begin{array}{l}4 \text { Conception within } 0-6 \text { months (exci- } \\
\text { sional treatment versus no treatment) }\end{array}$ & 2 & 175 & $\begin{array}{l}\text { Risk Ratio (IV, Random, 95\% } \\
\text { Cl) }\end{array}$ & $1.03[0.89,1.19]$ \\
\hline $\begin{array}{l}5 \text { Conception within } 0-9 \text { months (exci- } \\
\text { sional treatment versus no treatment) }\end{array}$ & 1 & 41 & $\begin{array}{l}\text { Risk Ratio (IV, Random, 95\% } \\
\text { Cl) }\end{array}$ & $1.03[0.66,1.59]$ \\
\hline $\begin{array}{l}6 \text { Conception within } 0-12 \text { months (exci- } \\
\text { sional treatment versus no treatment) }\end{array}$ & 2 & 175 & $\begin{array}{l}\text { Risk Ratio (IV, Random, 95\% } \\
\mathrm{Cl} \text { ) }\end{array}$ & $1.04[0.94,1.16]$ \\
\hline $\begin{array}{l}7 \text { Conception within } 0-24 \text { months (exci- } \\
\text { sional treatment versus no treatment) }\end{array}$ & 1 & 41 & $\begin{array}{l}\text { Risk Ratio (IV, Random, 95\% } \\
\mathrm{CI})\end{array}$ & $0.95[0.76,1.20]$ \\
\hline $\begin{array}{l}8 \text { Conception }>12 \text { months (treatment } \\
\text { versus no treatment) }\end{array}$ & 3 & 1348 & $\begin{array}{l}\text { Risk Ratio (IV, Random, 95\% } \\
\mathrm{CI})\end{array}$ & $1.27[0.67,2.39]$ \\
\hline $\begin{array}{l}8.1 \text { Excisional treatment versus no } \\
\text { treatment }\end{array}$ & 3 & 877 & $\begin{array}{l}\text { Risk Ratio (IV, Random, 95\% } \\
\text { Cl) }\end{array}$ & $1.04[0.41,2.63]$ \\
\hline $\begin{array}{l}8.2 \text { Ablative treatment versus no treat- } \\
\text { ment }\end{array}$ & 1 & 471 & $\begin{array}{l}\text { Risk Ratio (IV, Random, 95\% } \\
\mathrm{Cl} \text { ) }\end{array}$ & $1.92[1.00,3.68]$ \\
\hline
\end{tabular}




\begin{tabular}{|c|c|c|c|c|}
\hline Outcome or subgroup title & No. of studies & $\begin{array}{l}\text { No. of partici- } \\
\text { pants }\end{array}$ & Statistical method & Effect size \\
\hline $\begin{array}{l}9 \text { Conception }>12 \text { months (treatment } \\
\text { versus no treatment) }\end{array}$ & 3 & 1348 & $\begin{array}{l}\text { Risk Ratio (IV, Random, 95\% } \\
\mathrm{CI})\end{array}$ & $1.45[0.89,2.36]$ \\
\hline 9.1 CKC versus no treatment & 2 & 396 & $\begin{array}{l}\text { Risk Ratio (IV, Random, 95\% } \\
\mathrm{Cl} \text { ) }\end{array}$ & $1.51[0.78,2.92]$ \\
\hline 9.2 LEEP/LLETZ versus no treatment & 2 & 481 & $\begin{array}{l}\text { Risk Ratio (IV, Random, 95\% } \\
\mathrm{CI})\end{array}$ & $1.06[0.26,4.40]$ \\
\hline 9.3 Laser ablation versus no treatment & 1 & 132 & $\begin{array}{l}\text { Risk Ratio (IV, Random, 95\% } \\
\mathrm{CI})\end{array}$ & $2.71[0.95,7.67]$ \\
\hline 9.4 Cryotherapy versus no treatment & 1 & 339 & $\begin{array}{l}\text { Risk Ratio (IV, Random, 95\% } \\
\text { Cl) }\end{array}$ & $1.61[0.70,3.70]$ \\
\hline $\begin{array}{l}10 \text { Conception }>12 \text { months (col- } \\
\text { poscopy only versus no treatment) }\end{array}$ & 1 & 1172 & $\begin{array}{l}\text { Risk Ratio (IV, Random, 95\% } \\
\mathrm{CI})\end{array}$ & $1.02[0.59,1.79]$ \\
\hline $\begin{array}{l}11 \text { Conception >12 months (treatment } \\
\text { versus colposcopy only) }\end{array}$ & 1 & 303 & $\begin{array}{l}\text { Risk Ratio (IV, Random, 95\% } \\
\text { Cl) }\end{array}$ & $1.91[1.02,3.59]$ \\
\hline $\begin{array}{l}11.1 \text { Excisional treatment versus col- } \\
\text { poscopy only }\end{array}$ & 1 & 181 & $\begin{array}{l}\text { Risk Ratio (IV, Random, 95\% } \\
\mathrm{CI})\end{array}$ & $1.85[0.83,4.16]$ \\
\hline $\begin{array}{l}\text { 11.2 Ablative treatment versus col- } \\
\text { poscopy only }\end{array}$ & 1 & 122 & $\begin{array}{l}\text { Risk Ratio (IV, Random, 95\% } \\
\mathrm{CI})\end{array}$ & $2.0[0.73,5.51]$ \\
\hline $\begin{array}{l}12 \text { Conception }>12 \text { months (treatment } \\
\text { versus colposcopy only) }\end{array}$ & 1 & 303 & $\begin{array}{l}\text { Risk Ratio (IV, Random, 95\% } \\
\text { Cl) }\end{array}$ & $1.88[0.99,3.55]$ \\
\hline 12.1 CKC versus colposcopy only & 1 & 91 & $\begin{array}{l}\text { Risk Ratio (IV, Random, 95\% } \\
\mathrm{Cl} \text { ) }\end{array}$ & $1.71[0.54,5.45]$ \\
\hline $\begin{array}{l}\text { 12.2 LEEP/LLETZ versus colposcopy } \\
\text { only }\end{array}$ & 1 & 90 & $\begin{array}{l}\text { Risk Ratio (IV, Random, 95\% } \\
\text { Cl) }\end{array}$ & $2.0[0.65,6.17]$ \\
\hline $\begin{array}{l}12.3 \text { Laser ablation versus colposcopy } \\
\text { only }\end{array}$ & 1 & 34 & $\begin{array}{l}\text { Risk Ratio (IV, Random, 95\% } \\
\text { Cl) }\end{array}$ & $4.0[0.50,32.20]$ \\
\hline $\begin{array}{l}12.4 \text { Cryotherapy versus colposcopy } \\
\text { only }\end{array}$ & 1 & 88 & $\begin{array}{l}\text { Risk Ratio (IV, Random, 95\% } \\
\text { Cl) }\end{array}$ & $1.5[0.45,4.95]$ \\
\hline $\begin{array}{l}13 \text { Conception }>36 \text { months (treatment } \\
\text { versus no treatment) }\end{array}$ & 1 & 134 & $\begin{array}{l}\text { Risk Ratio (IV, Random, 95\% } \\
\text { Cl) }\end{array}$ & $0.69[0.19,2.45]$ \\
\hline
\end{tabular}

Analysis 1.1. Comparison 1 Fertility outcomes, Outcome 1 Total pregnancy rates.

\begin{tabular}{|c|c|c|c|c|c|}
\hline Study or subgroup & $\begin{array}{c}\text { Treated } \\
n / N\end{array}$ & $\begin{array}{l}\text { Untreated } \\
n / N\end{array}$ & $\begin{array}{c}\text { Risk Ratio } \\
\text { IV, Random, 95\% CI }\end{array}$ & Weight & $\begin{array}{c}\text { Risk Ratio } \\
\text { IV, Random, } 95 \% \mathrm{CI}\end{array}$ \\
\hline \multicolumn{6}{|c|}{ 1.1.1 LEEP/LLETZ versus no treatment } \\
\hline Bigrigg 1994 & $76 / 229$ & $66 / 229$ & $\longrightarrow$ & $19.93 \%$ & $1.15[0.88,1.51]$ \\
\hline
\end{tabular}




\begin{tabular}{|c|c|c|c|c|c|}
\hline Study or subgroup & $\begin{array}{c}\text { Treated } \\
n / N\end{array}$ & $\begin{array}{c}\text { Untreated } \\
n / N\end{array}$ & $\begin{array}{c}\text { Risk Ratio } \\
\text { IV, Random, 95\% CI }\end{array}$ & Weight & $\begin{array}{c}\text { Risk Ratio } \\
\text { IV, Random, } 95 \% \text { CI }\end{array}$ \\
\hline Turlington 1996 & $15 / 54$ & $21 / 57$ & \begin{tabular}{l|l}
$\longrightarrow$ & \\
\end{tabular} & $11.12 \%$ & $0.75[0.44,1.3]$ \\
\hline Subtotal $(95 \% \mathrm{CI})$ & 283 & 286 & & $31.05 \%$ & $1[0.67,1.48]$ \\
\hline \multicolumn{6}{|c|}{ Total events: 91 (Treated), 87 (Untreated) } \\
\hline \multicolumn{6}{|c|}{ Heterogeneity: $\mathrm{Tau}^{2}=0.04 ; \mathrm{Chi}^{2}=1.83, \mathrm{df}=1(\mathrm{P}=0.18) ; \mathrm{I}^{2}=45.47 \%$} \\
\hline \multicolumn{6}{|c|}{ Test for overall effect: $Z=0.01(P=0.99)$} \\
\hline \multicolumn{6}{|c|}{ 1.1.2 Laser conisation versus no treatment } \\
\hline Spitzer 1995 & $67 / 100$ & $28 / 100$ & $\longrightarrow$ & $17.34 \%$ & $2.39[1.7,3.37]$ \\
\hline Subtotal $(95 \% \mathrm{CI})$ & 100 & 100 & & $17.34 \%$ & $2.39[1.7,3.37]$ \\
\hline \multicolumn{6}{|c|}{ Total events: 67 (Treated), 28 (Untreated) } \\
\hline \multicolumn{6}{|c|}{ Heterogeneity: Not applicable } \\
\hline \multicolumn{6}{|c|}{ Test for overall effect: $Z=4.98(P<0.0001)$} \\
\hline \multicolumn{6}{|c|}{ 1.1.3 Laser ablation versus no treatment } \\
\hline Spitzer 1995 & $210 / 333$ & $149 / 333$ & $\rightarrow-$ & $24.63 \%$ & $1.41[1.22,1.63]$ \\
\hline Subtotal $(95 \% \mathrm{CI})$ & 333 & 333 & & $24.63 \%$ & $1.41[1.22,1.63]$ \\
\hline \multicolumn{6}{|c|}{ Total events: 210 (Treated), 149 (Untreated) } \\
\hline \multicolumn{6}{|c|}{ Heterogeneity: Not applicable } \\
\hline \multicolumn{6}{|c|}{ Test for overall effect: $Z=4.64(P<0.0001)$} \\
\hline \multicolumn{6}{|c|}{ 1.1.4 Treatment not specified versus no treatment } \\
\hline Kallialla 2012 & $2578 / 6179$ & $11642 / 30436$ & i & $26.97 \%$ & $1.09[1.06,1.13]$ \\
\hline Subtotal $(95 \% \mathrm{Cl})$ & 6179 & 30436 & 1 & $26.97 \%$ & $1.09[1.06,1.13]$ \\
\hline \multicolumn{6}{|c|}{ Total events: 2578 (Treated), 11642 (Untreated) } \\
\hline \multicolumn{6}{|c|}{ Heterogeneity: Not applicable } \\
\hline \multicolumn{6}{|c|}{ Test for overall effect: $Z=5.2(P<0.0001)$} \\
\hline Total $(95 \% \mathrm{Cl})$ & 6895 & 31155 & & $100 \%$ & $1.29[1.02,1.64]$ \\
\hline \multicolumn{6}{|c|}{ Total events: 2946 (Treated), 11906 (Untreated) } \\
\hline \multicolumn{6}{|c|}{ Heterogeneity: $\mathrm{Tau}^{2}=0.05 ; \mathrm{Chi}^{2}=32.76, \mathrm{df}=4(\mathrm{P}<0.0001) ;\left.\right|^{2}=87.79 \%$} \\
\hline \multicolumn{6}{|c|}{ Test for overall effect: $Z=2.11(P=0.04)$} \\
\hline Test for subgroup dif & $6, \mathrm{df}=1(P<0.000$ & ${ }^{2}=90.34 \%$ & & & \\
\hline
\end{tabular}

Analysis 1.2. Comparison 1 Fertility outcomes, Outcome 2 Pregnancy rate in women with intention to conceive.

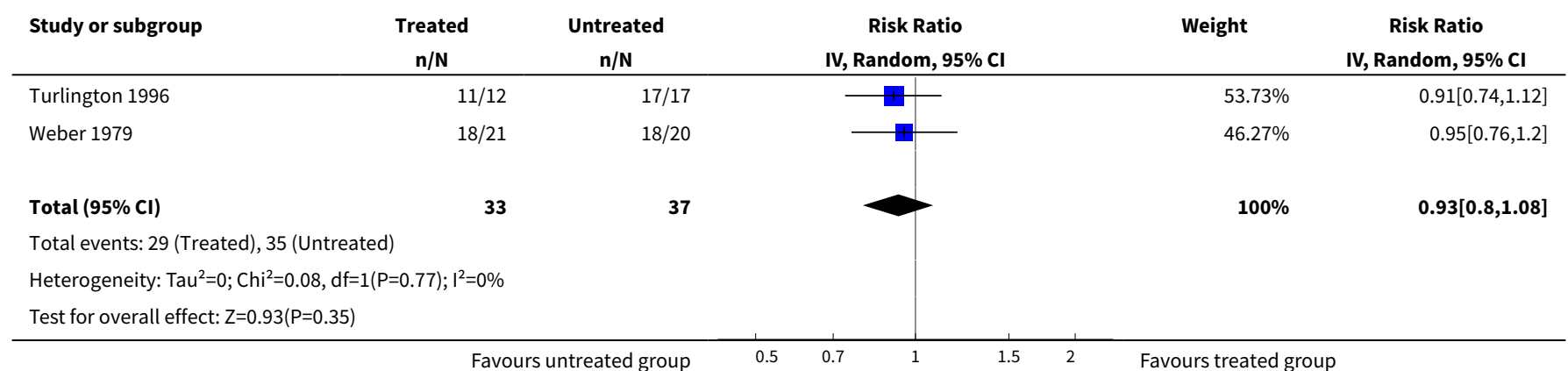


Analysis 1.3. Comparison 1 Fertility outcomes, Outcome 3 Conception within 0-3 months (excisional treatment versus no treatment).

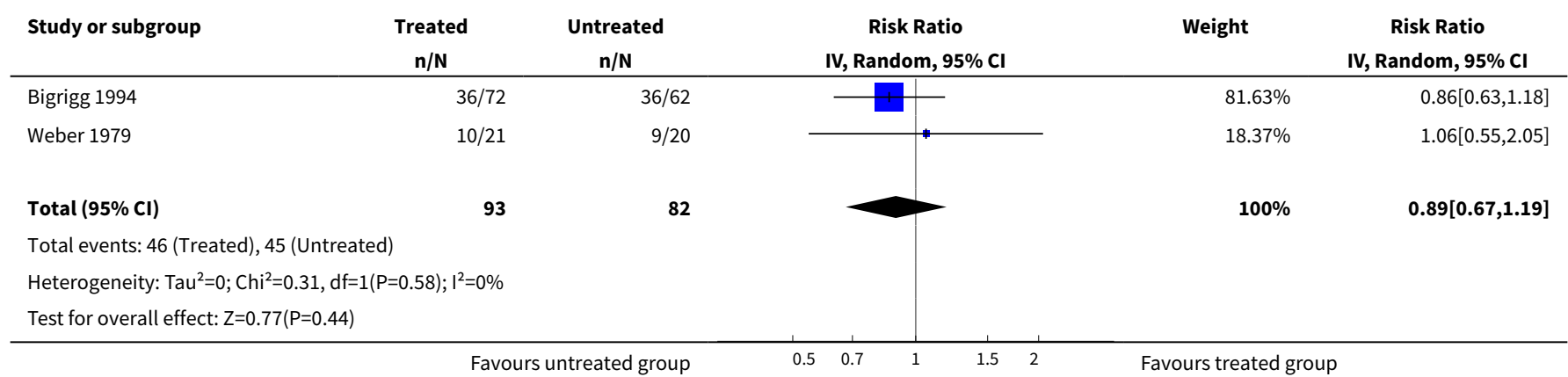

Analysis 1.4. Comparison 1 Fertility outcomes, Outcome 4 Conception within 0-6 months (excisional treatment versus no treatment).

\begin{tabular}{|c|c|c|c|c|c|}
\hline Study or subgroup & $\begin{array}{c}\text { Treated } \\
\mathrm{n} / \mathrm{N}\end{array}$ & $\begin{array}{c}\text { Untreated } \\
\mathrm{n} / \mathrm{N} \\
\end{array}$ & $\begin{array}{c}\text { Risk Ratio } \\
\text { IV, Random, 95\% CI }\end{array}$ & Weight & $\begin{array}{c}\text { Risk Ratio } \\
\text { IV, Random, } 95 \% \mathrm{CI} \\
\end{array}$ \\
\hline Bigrigg 1994 & $61 / 72$ & $51 / 62$ & & $92.76 \%$ & $1.03[0.89,1.2]$ \\
\hline Weber 1979 & $12 / 21$ & $11 / 20$ & & $7.24 \%$ & $1.04[0.6,1.79]$ \\
\hline Total $(95 \% \mathrm{Cl})$ & 93 & 82 & & $100 \%$ & $1.03[0.89,1.19]$ \\
\hline \multicolumn{6}{|c|}{ Total events: 73 (Treated), 62 (Untreated) } \\
\hline Test for overall effect & & & & & \\
\hline
\end{tabular}

Analysis 1.5. Comparison 1 Fertility outcomes, Outcome 5 Conception within 0-9 months (excisional treatment versus no treatment).

\begin{tabular}{|c|c|c|c|c|c|}
\hline Study or subgroup & $\begin{array}{c}\text { Treated } \\
\text { n/N }\end{array}$ & $\begin{array}{l}\text { Untreated } \\
\qquad \mathrm{n} / \mathrm{N}\end{array}$ & $\begin{array}{c}\text { Risk Ratio } \\
\text { IV, Random, } 95 \% \mathrm{Cl}\end{array}$ & Weight & $\begin{array}{c}\text { Risk Ratio } \\
\text { IV, Random, } 95 \% \text { CI }\end{array}$ \\
\hline Weber 1979 & $14 / 21$ & $13 / 20$ & 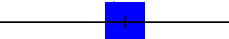 & $100 \%$ & $1.03[0.66,1.59]$ \\
\hline Total $(95 \% \mathrm{Cl})$ & 21 & 20 & & $100 \%$ & $1.03[0.66,1.59]$ \\
\hline \multicolumn{6}{|c|}{ Total events: 14 (Treated), 13 (Untreated) } \\
\hline \multicolumn{6}{|c|}{ Heterogeneity: Not applicable } \\
\hline
\end{tabular}

Analysis 1.6. Comparison 1 Fertility outcomes, Outcome 6 Conception within 0-12 months (excisional treatment versus no treatment).

\begin{tabular}{|c|c|c|c|c|c|}
\hline Study or subgroup & $\begin{array}{c}\text { Treated } \\
n / N\end{array}$ & $\begin{array}{l}\text { Untreated } \\
\mathbf{n} / \mathbf{N}\end{array}$ & $\begin{array}{c}\text { Risk Ratio } \\
\text { IV, Random, 95\% CI }\end{array}$ & Weight & $\begin{array}{c}\text { Risk Ratio } \\
\text { IV, Random, } 95 \% \text { CI }\end{array}$ \\
\hline Bigrigg 1994 & $67 / 72$ & $55 / 62$ & - & $93.61 \%$ & $1.05[0.94,1.17]$ \\
\hline
\end{tabular}




\begin{tabular}{|c|c|c|c|c|c|}
\hline Study or subgroup & $\begin{array}{c}\text { Treated } \\
\mathrm{n} / \mathrm{N}\end{array}$ & $\begin{array}{c}\text { Untreated } \\
\mathrm{n} / \mathrm{N} \\
\end{array}$ & $\begin{array}{c}\text { Risk Ratio } \\
\text { IV, Random, } 95 \% \mathrm{Cl} \\
\end{array}$ & Weight & $\begin{array}{c}\text { Risk Ratio } \\
\text { IV, Random, } 95 \% \mathrm{CI} \\
\end{array}$ \\
\hline Weber 1979 & $14 / 21$ & $14 / 20$ & $\longrightarrow$ & $6.39 \%$ & $0.95[0.63,1.44]$ \\
\hline Total $(95 \% \mathrm{Cl})$ & 93 & 82 & & $100 \%$ & $1.04[0.94,1.16]$ \\
\hline \multicolumn{6}{|c|}{ Total events: 81 (Treated), 69 (Untreated) } \\
\hline \multicolumn{6}{|c|}{ Heterogeneity: $\mathrm{Tau}^{2}=0 ; \mathrm{Chi}^{2}=0.19, \mathrm{df}=1(\mathrm{P}=0.66) ; \mathrm{I}^{2}=0 \%$} \\
\hline \multicolumn{6}{|c|}{ Test for overall effect: $\mathrm{Z}=0.77(\mathrm{P}=0.44)$} \\
\hline
\end{tabular}

Analysis 1.7. Comparison 1 Fertility outcomes, Outcome 7 Conception within 0-24 months (excisional treatment versus no treatment).

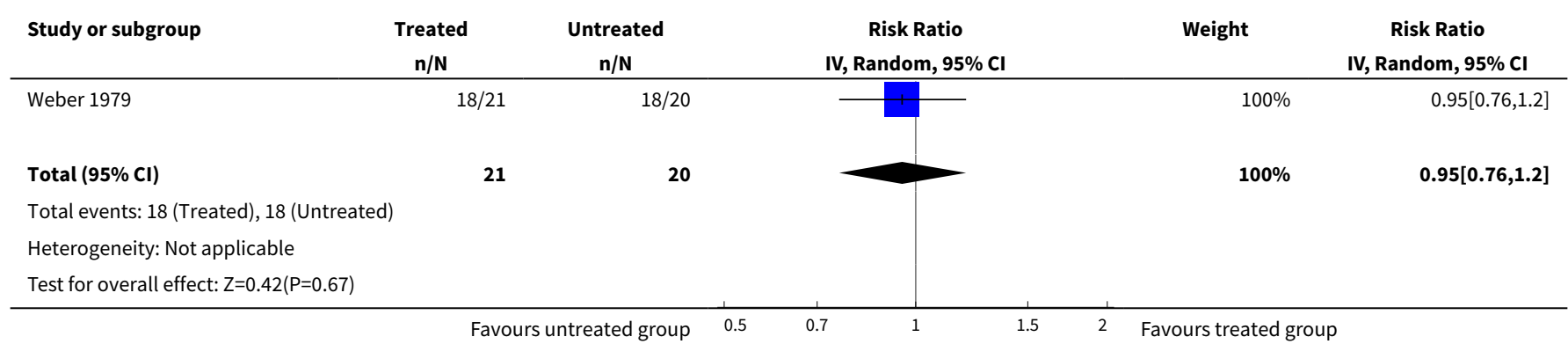

Analysis 1.8. Comparison 1 Fertility outcomes, Outcome 8 Conception $>12$ months (treatment versus no treatment).

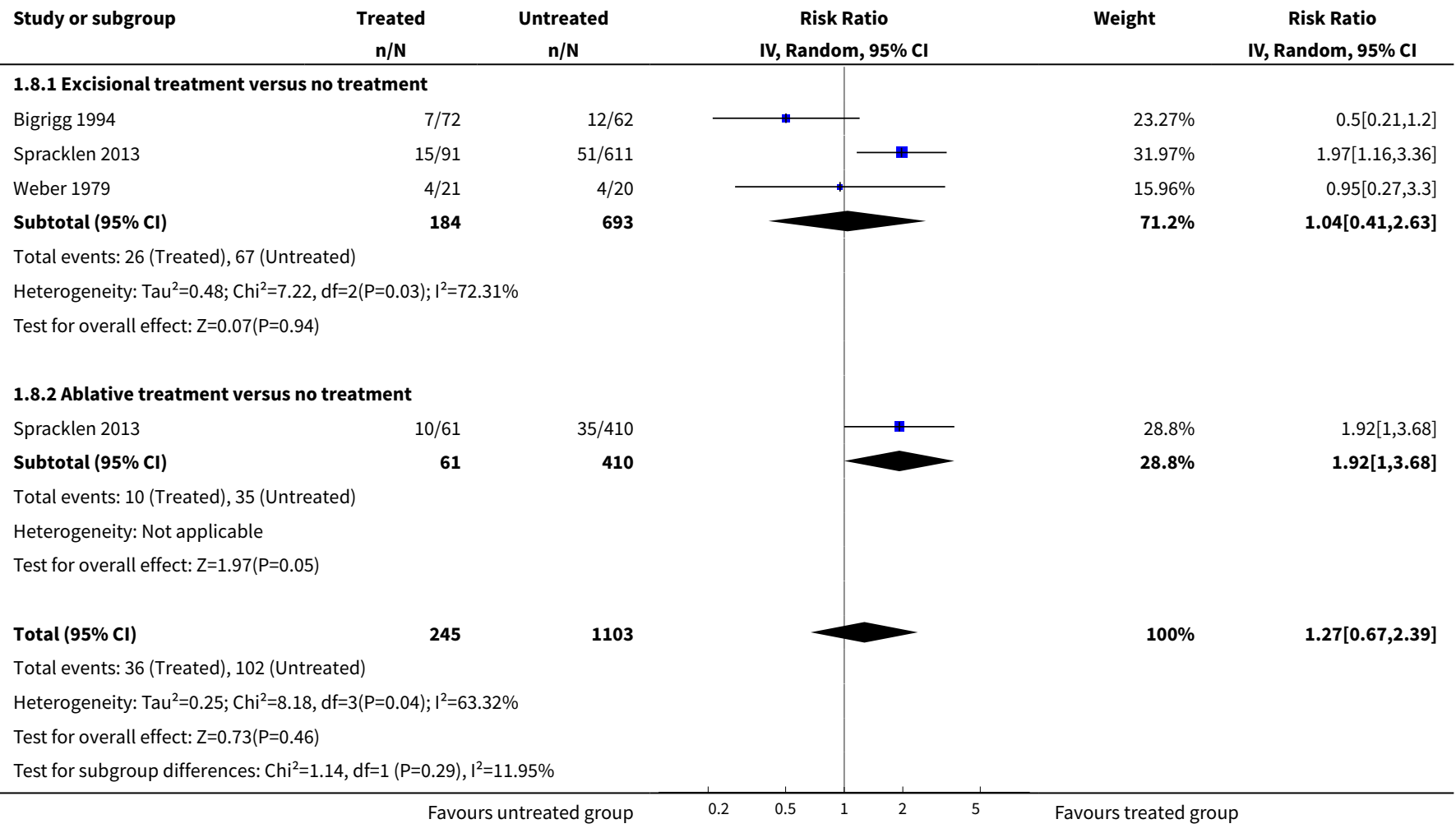


Analysis 1.9. Comparison 1 Fertility outcomes, Outcome 9 Conception $>12$ months (treatment versus no treatment).

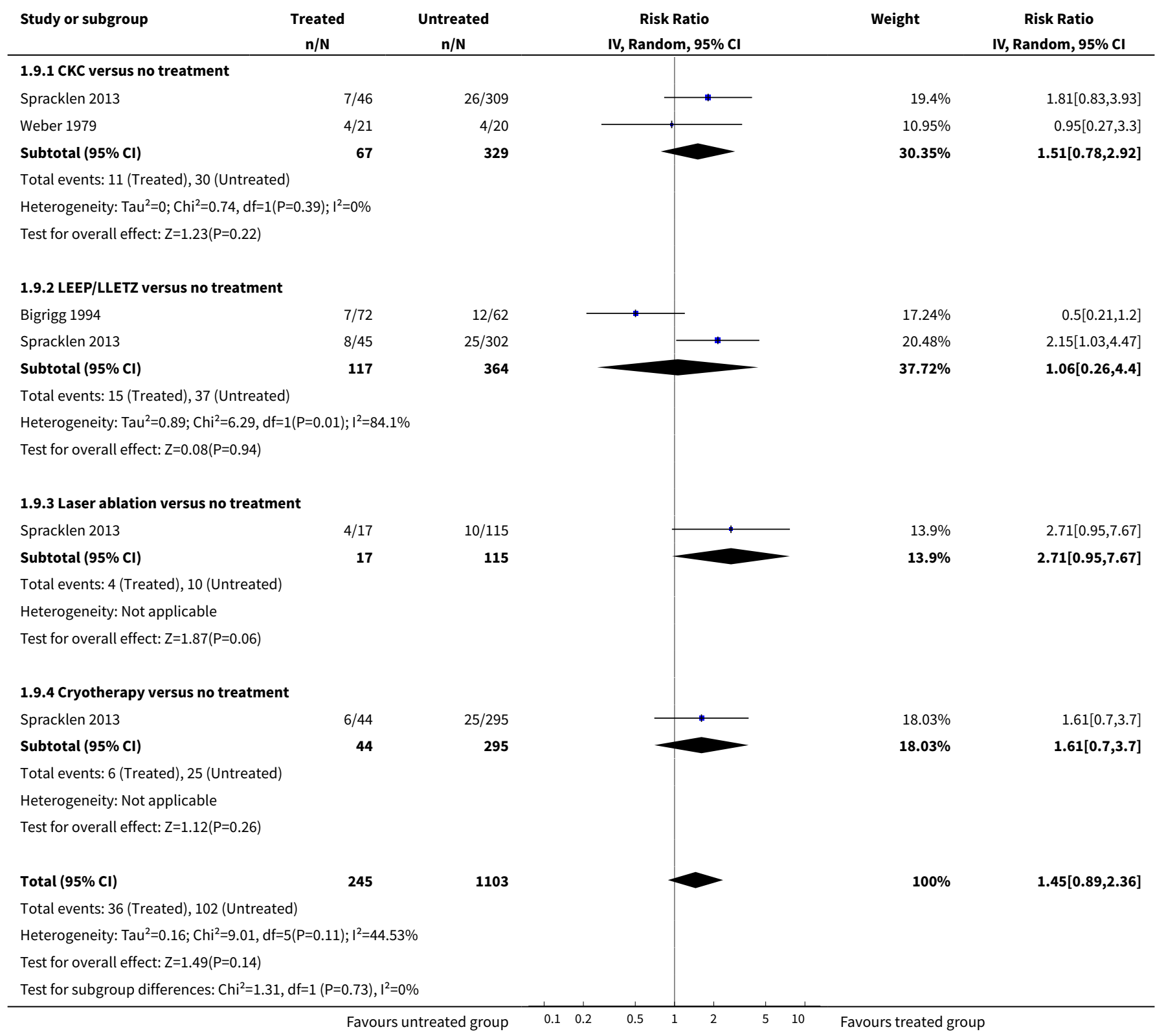

Analysis 1.10. Comparison 1 Fertility outcomes, Outcome 10 Conception $>12$ months (colposcopy only versus no treatment).

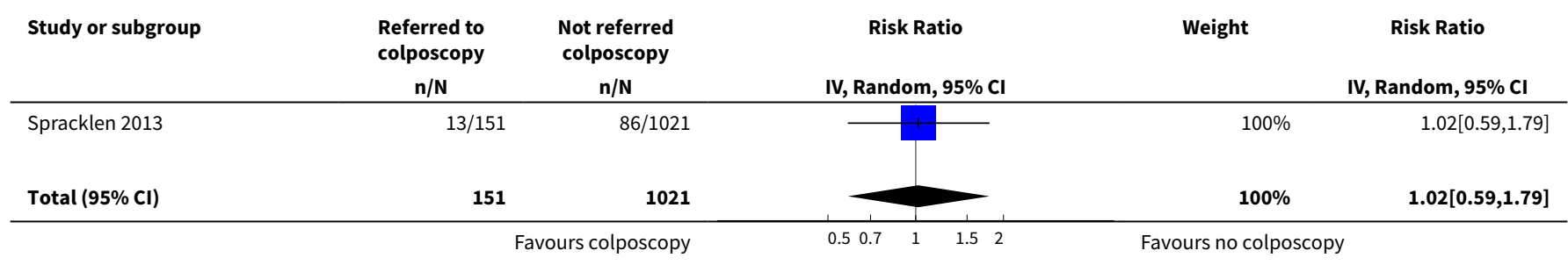




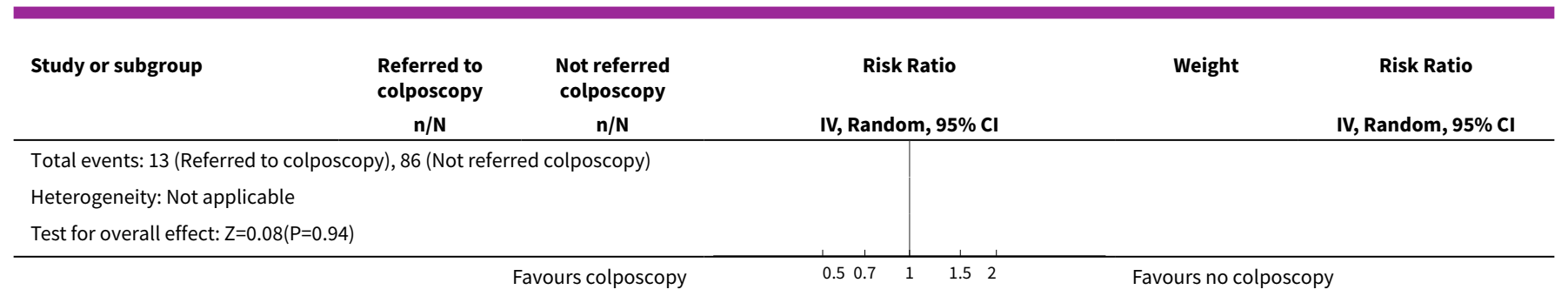

Analysis 1.11. Comparison 1 Fertility outcomes, Outcome 11 Conception >12 months (treatment versus colposcopy only).

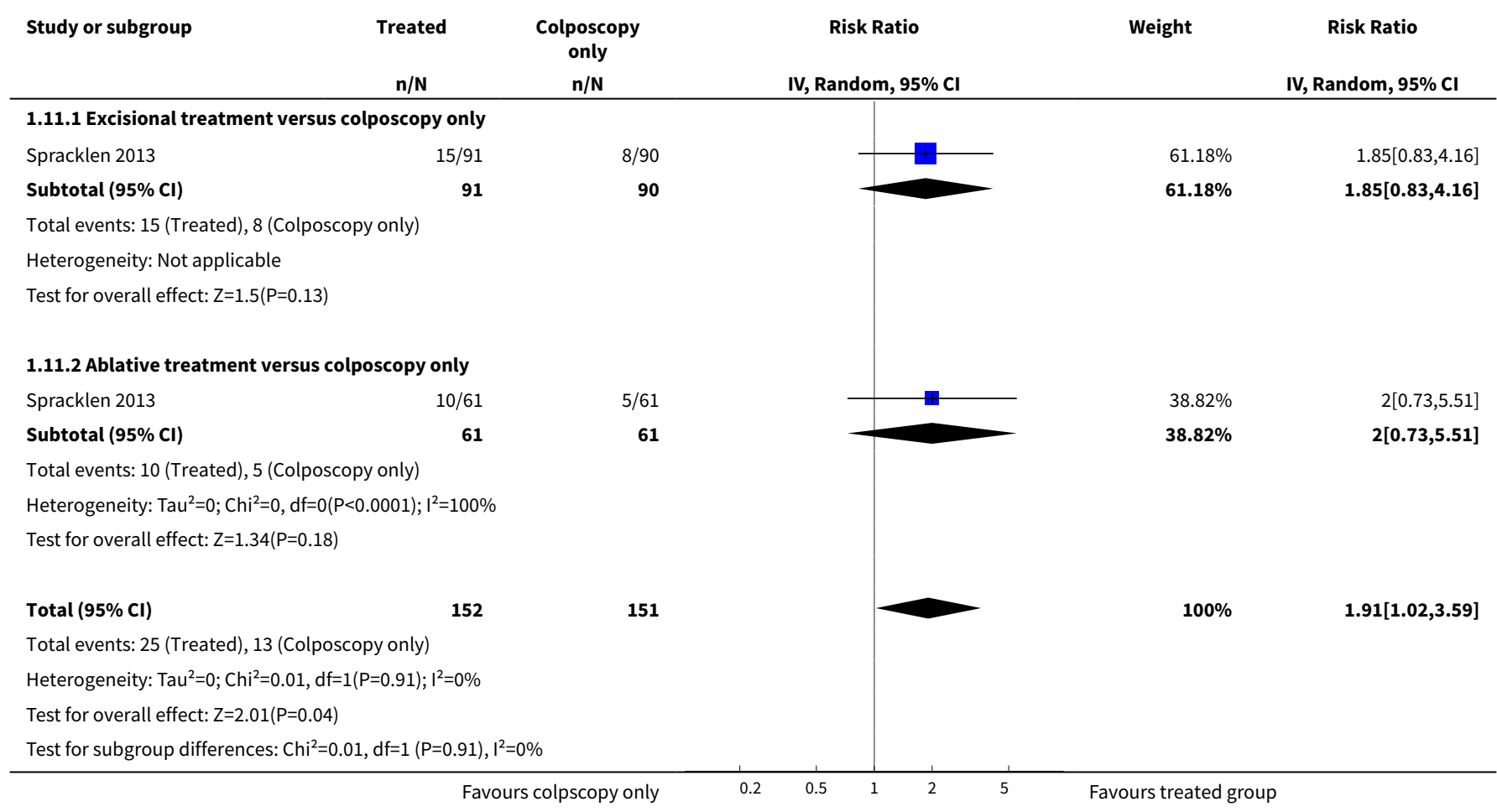

Analysis 1.12. Comparison 1 Fertility outcomes, Outcome 12 Conception >12 months (treatment versus colposcopy only).

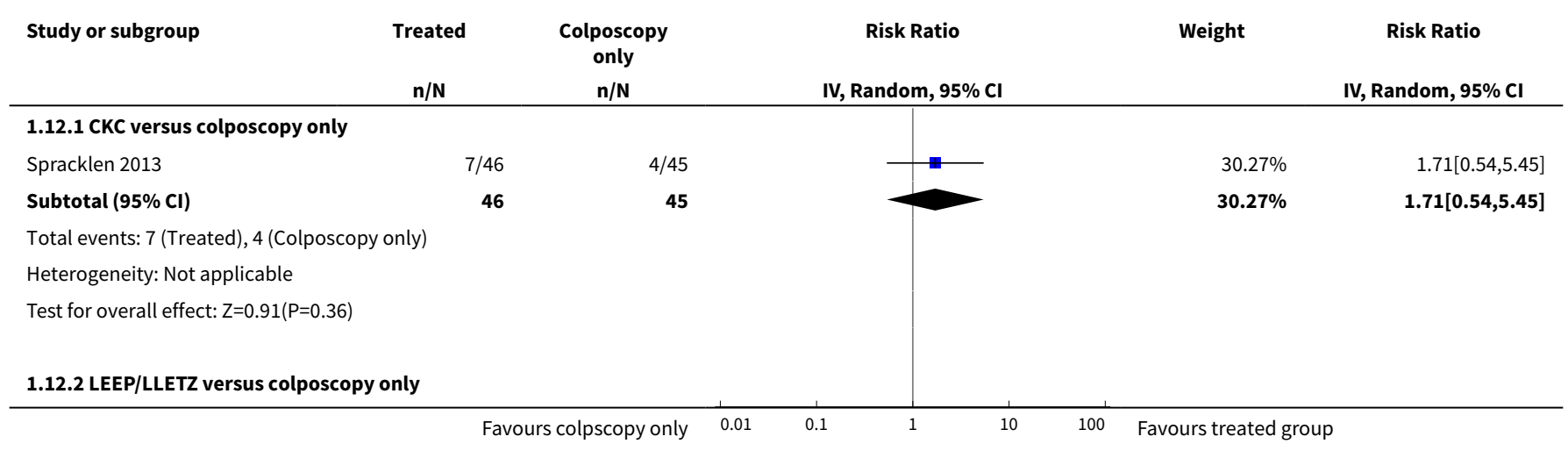




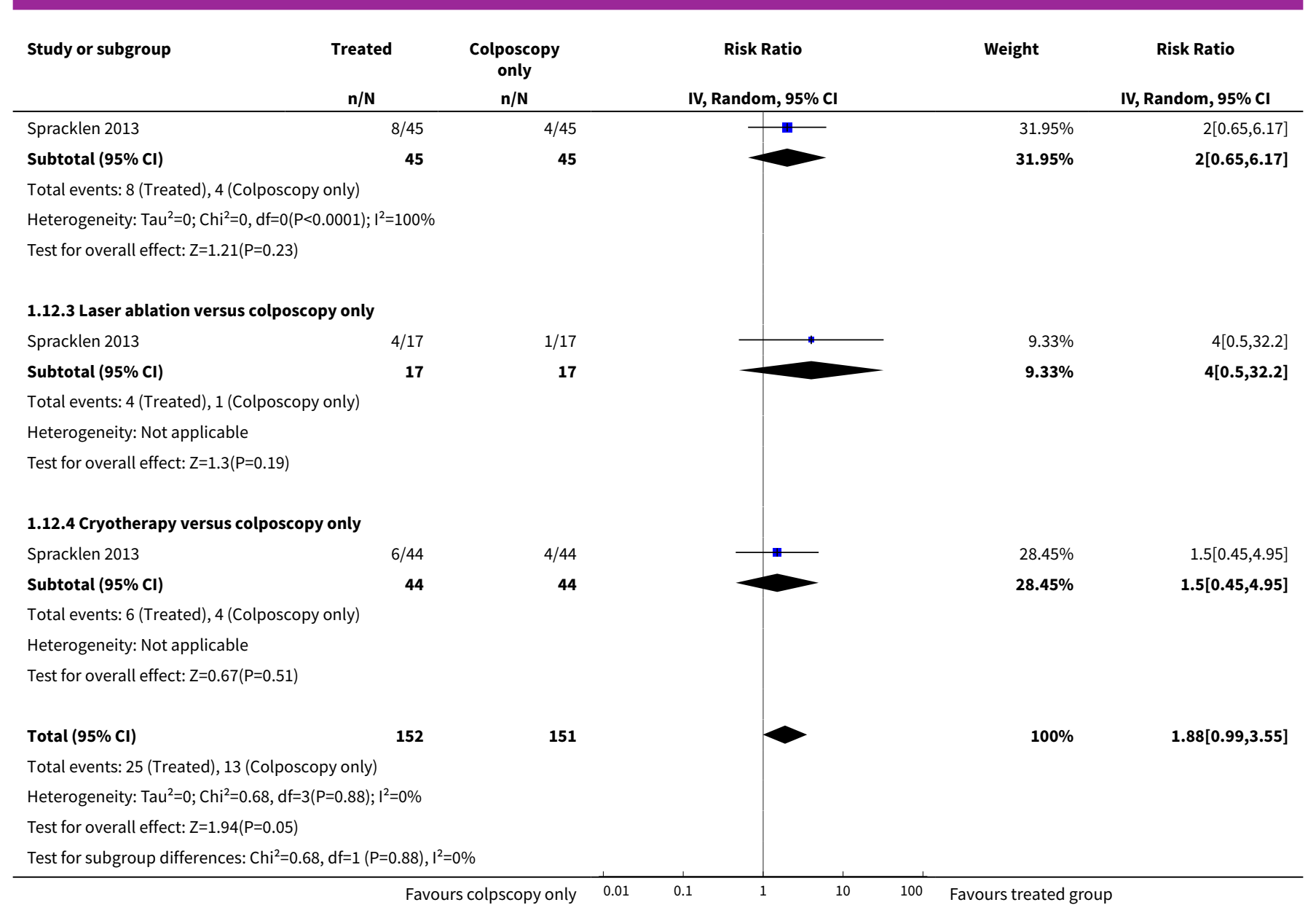

Analysis 1.13. Comparison 1 Fertility outcomes, Outcome 13 Conception $>36$ months (treatment versus no treatment).

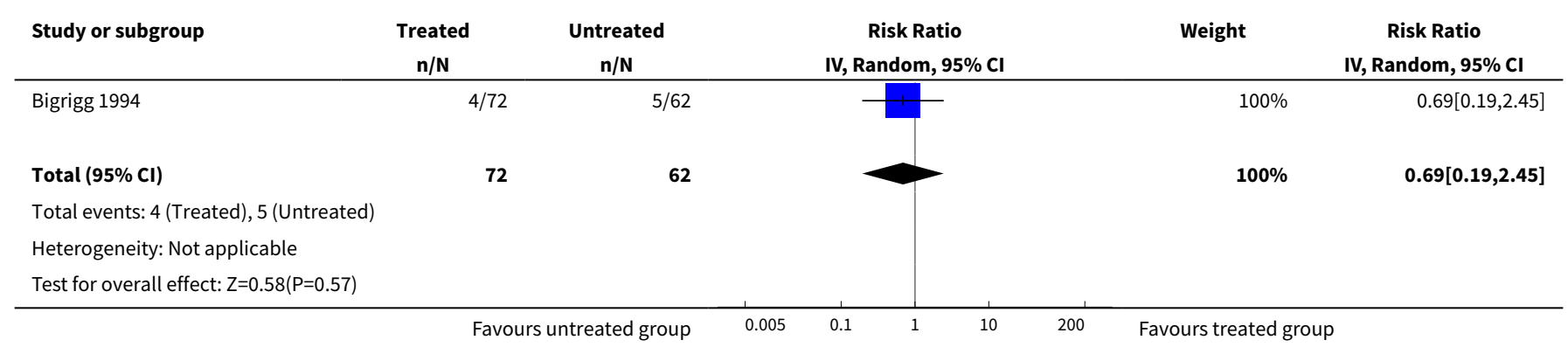

\section{Comparison 2. Early pregnancy outcomes}

\begin{tabular}{lllll}
\hline Outcome or subgroup title & No. of studies & $\begin{array}{l}\text { No. of partici- } \\
\text { pants }\end{array}$ & Statistical method & Effect size \\
\hline $\begin{array}{l}1 \text { Miscarriage rates (treatment versus } \\
\text { no treatment) }\end{array}$ & 10 & 39504 & $\begin{array}{l}\text { Risk Ratio (IV, Random, 95\% } \\
\text { Cl) }\end{array}$ & $1.04[0.90,1.21]$ \\
\hline
\end{tabular}




\begin{tabular}{|c|c|c|c|c|}
\hline Outcome or subgroup title & No. of studies & $\begin{array}{l}\text { No. of partici- } \\
\text { pants }\end{array}$ & Statistical method & Effect size \\
\hline $\begin{array}{l}\text { 1.1 Excisional treatment versus no } \\
\text { treatment }\end{array}$ & 9 & 2530 & $\begin{array}{l}\text { Risk Ratio (IV, Random, 95\% } \\
\text { CI) }\end{array}$ & $1.07[0.87,1.31]$ \\
\hline $\begin{array}{l}\text { 1.2 Ablative treatment versus no treat- } \\
\text { ment }\end{array}$ & 1 & 359 & $\begin{array}{l}\text { Risk Ratio (IV, Random, 95\% } \\
\mathrm{CI} \text { ) }\end{array}$ & $0.65[0.39,1.09]$ \\
\hline $\begin{array}{l}1.3 \text { Treatment not specified versus no } \\
\text { treatment }\end{array}$ & 1 & 36615 & $\begin{array}{l}\text { Risk Ratio (IV, Random, 95\% } \\
\text { CI) }\end{array}$ & $1.11[0.93,1.31]$ \\
\hline $\begin{array}{l}2 \text { Miscarriage rates (treatment versus } \\
\text { no treatment) }\end{array}$ & 10 & 39504 & $\begin{array}{l}\text { Risk Ratio (IV, Random, 95\% } \\
\text { CI) }\end{array}$ & $1.04[0.90,1.21]$ \\
\hline 2.1 CKC versus no treatment & 3 & 950 & $\begin{array}{l}\text { Risk Ratio (IV, Random, 95\% } \\
\text { CI) }\end{array}$ & $1.30[0.92,1.83]$ \\
\hline 2.2 LLETZ/LEEP versus no treatment & 4 & 1332 & $\begin{array}{l}\text { Risk Ratio (IV, Random, 95\% } \\
\text { CI) }\end{array}$ & $1.03[0.77,1.36]$ \\
\hline $\begin{array}{l}2.3 \text { Laser conisation versus no treat- } \\
\text { ment }\end{array}$ & 2 & 248 & $\begin{array}{l}\text { Risk Ratio (IV, Random, 95\% } \\
\text { Cl) }\end{array}$ & $0.69[0.28,1.69]$ \\
\hline 2.4 Laser ablation versus no treatment & 1 & 359 & $\begin{array}{l}\text { Risk Ratio (IV, Random, 95\% } \\
\text { Cl) }\end{array}$ & $0.65[0.39,1.09]$ \\
\hline $\begin{array}{l}2.5 \text { Treatment not specified versus no } \\
\text { treatment }\end{array}$ & 1 & 36615 & $\begin{array}{l}\text { Risk Ratio (IV, Random, 95\% } \\
\mathrm{CI} \text { ) }\end{array}$ & $1.11[0.93,1.31]$ \\
\hline $\begin{array}{l}3 \text { 1st trimester Miscarriage rates (treat- } \\
\text { ment versus no treatment) }\end{array}$ & 4 & 1103 & $\begin{array}{l}\text { Risk Ratio (IV, Random, 95\% } \\
\mathrm{CI} \text { ) }\end{array}$ & $1.16[0.80,1.69]$ \\
\hline 3.1 CKC versus no treatment & 3 & 950 & $\begin{array}{l}\text { Risk Ratio (IV, Random, 95\% } \\
\mathrm{CI} \text { ) }\end{array}$ & $1.20[0.78,1.83]$ \\
\hline $\begin{array}{l}\text { 3.2 Laser Conisation versus no treat- } \\
\text { ment }\end{array}$ & 1 & 153 & $\begin{array}{l}\text { Risk Ratio (IV, Random, 95\% } \\
\mathrm{CI})\end{array}$ & $1.05[0.47,2.33]$ \\
\hline $\begin{array}{l}4 \text { 2nd trimester miscarriage rates } \\
\text { (treatment versus no treatment) }\end{array}$ & 8 & $2.182268 \mathrm{E} 6$ & $\begin{array}{l}\text { Risk Ratio (IV, Random, 95\% } \\
\mathrm{CI} \text { ) }\end{array}$ & $2.61[1.46,4.65]$ \\
\hline 4.1 CKC versus no treatment & 3 & 950 & $\begin{array}{l}\text { Risk Ratio (IV, Random, 95\% } \\
\mathrm{CI} \text { ) }\end{array}$ & $1.55[0.79,3.01]$ \\
\hline 4.2 LLETZ/LEEP versus no treatment & 2 & 567 & $\begin{array}{l}\text { Risk Ratio (IV, Random, 95\% } \\
\mathrm{CI} \text { ) }\end{array}$ & $1.98[0.48,8.21]$ \\
\hline $\begin{array}{l}4.3 \text { Laser conisation versus no treat- } \\
\text { ment }\end{array}$ & 1 & 153 & $\begin{array}{l}\text { Risk Ratio (IV, Random, 95\% } \\
\text { CI) }\end{array}$ & $0.0[0.0,0.0]$ \\
\hline $\begin{array}{l}\text { 4.4 Excisional treatment not specified } \\
\text { versus no treatment }\end{array}$ & 2 & 2.180598E6 & $\begin{array}{l}\text { Risk Ratio (IV, Random, 95\% } \\
\text { CI) }\end{array}$ & $3.82[3.35,4.35]$ \\
\hline $\begin{array}{l}5 \text { Ectopic pregnancy (treatment versus } \\
\text { no treatment) }\end{array}$ & 6 & 38193 & $\begin{array}{l}\text { Risk Ratio (IV, Random, 95\% } \\
\text { CI) }\end{array}$ & $1.89[1.50,2.39]$ \\
\hline
\end{tabular}




\begin{tabular}{|c|c|c|c|c|}
\hline Outcome or subgroup title & No. of studies & $\begin{array}{l}\text { No. of partici- } \\
\text { pants }\end{array}$ & Statistical method & Effect size \\
\hline $\begin{array}{l}5.1 \text { Excisional treatment versus no } \\
\text { treatment }\end{array}$ & 5 & 1219 & $\begin{array}{l}\text { Risk Ratio (IV, Random, 95\% } \\
\text { CI) }\end{array}$ & $1.76[0.62,5.02]$ \\
\hline $\begin{array}{l}5.2 \text { Ablative treatment versus no treat- } \\
\text { ment }\end{array}$ & 1 & 359 & $\begin{array}{l}\text { Risk Ratio (IV, Random, 95\% } \\
\mathrm{Cl} \text { ) }\end{array}$ & $1.77[0.35,9.02]$ \\
\hline $\begin{array}{l}5.3 \text { Treatment not specified versusno } \\
\text { treatment }\end{array}$ & 1 & 36615 & $\begin{array}{l}\text { Risk Ratio (IV, Random, 95\% } \\
\text { CI) }\end{array}$ & $1.91[1.50,2.44]$ \\
\hline $\begin{array}{l}6 \text { Ectopic pregnancy (treatment versus } \\
\text { no treatment) }\end{array}$ & 6 & 38193 & $\begin{array}{l}\text { Risk Ratio (IV, Random, 95\% } \\
\text { CI) }\end{array}$ & $1.89[1.50,2.39]$ \\
\hline 6.1 CKC versus no treatment & 2 & 829 & $\begin{array}{l}\text { Risk Ratio (IV, Random, 95\% } \\
\mathrm{CI} \text { ) }\end{array}$ & $6.83[1.50,31.02]$ \\
\hline 6.2 LLETZ/LEEP versus no treatment & 1 & 142 & $\begin{array}{l}\text { Risk Ratio (IV, Random, 95\% } \\
\mathrm{CI} \text { ) }\end{array}$ & $0.87[0.13,6.00]$ \\
\hline $\begin{array}{l}6.3 \text { Laser conisation versus no treat- } \\
\text { ment }\end{array}$ & 2 & 248 & $\begin{array}{l}\text { Risk Ratio (IV, Random, 95\% } \\
\mathrm{CI} \text { ) }\end{array}$ & $0.82[0.23,2.99]$ \\
\hline 6.4 Laser ablation versus no treatment & 1 & 359 & $\begin{array}{l}\text { Risk Ratio (IV, Random, 95\% } \\
\text { Cl) }\end{array}$ & $1.77[0.35,9.02]$ \\
\hline $\begin{array}{l}6.5 \text { Treatment not specified versus no } \\
\text { treatment }\end{array}$ & 1 & 36615 & $\begin{array}{l}\text { Risk Ratio (IV, Random, 95\% } \\
\text { CI) }\end{array}$ & $1.91[1.50,2.44]$ \\
\hline $\begin{array}{l}7 \text { Molar pregnancy rates (treatment } \\
\text { versus no treatment) }\end{array}$ & 2 & 36809 & Risk Ratio (IV, Fixed, 95\% Cl) & $1.08[0.80,1.47]$ \\
\hline 7.1 CKC versus no treatment & 1 & 194 & Risk Ratio (IV, Fixed, 95\% CI) & $0.40[0.02,9.72]$ \\
\hline $\begin{array}{l}7.2 \text { Treatment not specified versus no } \\
\text { treatment }\end{array}$ & 1 & 36615 & Risk Ratio (IV, Fixed, 95\% Cl) & $1.09[0.81,1.49]$ \\
\hline $\begin{array}{l}8 \text { Termination of pregnancy rates } \\
\text { (Treatment versus no treatment) }\end{array}$ & 7 & 38208 & $\begin{array}{l}\text { Risk Ratio (IV, Random, 95\% } \\
\mathrm{CI} \text { ) }\end{array}$ & $1.71[1.31,2.22]$ \\
\hline $\begin{array}{l}8.1 \text { Excisional treatment versus no } \\
\text { treatment }\end{array}$ & 6 & 1234 & $\begin{array}{l}\text { Risk Ratio (IV, Random, 95\% } \\
\text { CI) }\end{array}$ & $1.87[1.12,3.11]$ \\
\hline $\begin{array}{l}8.2 \text { Ablative treatment versus no treat- } \\
\text { ment }\end{array}$ & 1 & 359 & $\begin{array}{l}\text { Risk Ratio (IV, Random, 95\% } \\
\text { CI) }\end{array}$ & $1.54[0.99,2.38]$ \\
\hline $\begin{array}{l}8.3 \text { Treatment not specified versus no } \\
\text { treatment }\end{array}$ & 1 & 36615 & $\begin{array}{l}\text { Risk Ratio (IV, Random, 95\% } \\
\text { Cl) }\end{array}$ & $1.52[1.41,1.65]$ \\
\hline $\begin{array}{l}9 \text { Termination of pregnancy rates } \\
\text { (treatment versus no treatment) }\end{array}$ & 7 & 38208 & $\begin{array}{l}\text { Risk Ratio (IV, Random, 95\% } \\
\text { Cl) }\end{array}$ & $1.71[1.31,2.22]$ \\
\hline 9.1 CKC versus no treatment & 3 & 950 & $\begin{array}{l}\text { Risk Ratio (IV, Random, 95\% } \\
\text { CI) }\end{array}$ & $2.45[1.68,3.58]$ \\
\hline 9.2 LLETZ/LEEP versus no treatment & 1 & 36 & $\begin{array}{l}\text { Risk Ratio (IV, Random, 95\% } \\
\text { CI) }\end{array}$ & $0.28[0.01,5.35]$ \\
\hline
\end{tabular}




\begin{tabular}{lllll}
\hline Outcome or subgroup title & No. of studies & $\begin{array}{l}\text { No. of partici- } \\
\text { pants }\end{array}$ & Statistical method & Effect size \\
\hline $\begin{array}{l}\text { 9.3 Laser conisation versus no treat- } \\
\text { ment }\end{array}$ & 2 & 248 & $\begin{array}{l}\text { Risk Ratio (IV, Random, 95\% } \\
\text { CI) }\end{array}$ & $1.29[0.38,4.36]$ \\
\hline 9.4 Laser ablation versus no treatment & 1 & 359 & $\begin{array}{l}\text { Risk Ratio (IV, Random, 95\% } \\
\text { Cl) }\end{array}$ & $1.54[0.99,2.38]$ \\
\hline $\begin{array}{l}\text { 9.5 Treatment not specified versus no } \\
\text { treatment }\end{array}$ & 1 & 36615 & $\begin{array}{l}\text { Risk Ratio (IV, Random, 95\% } \\
\text { CI) }\end{array}$ & $1.52[1.41,1.65]$ \\
\hline
\end{tabular}

Analysis 2.1. Comparison 2 Early pregnancy outcomes, Outcome 1 Miscarriage rates (treatment versus no treatment).

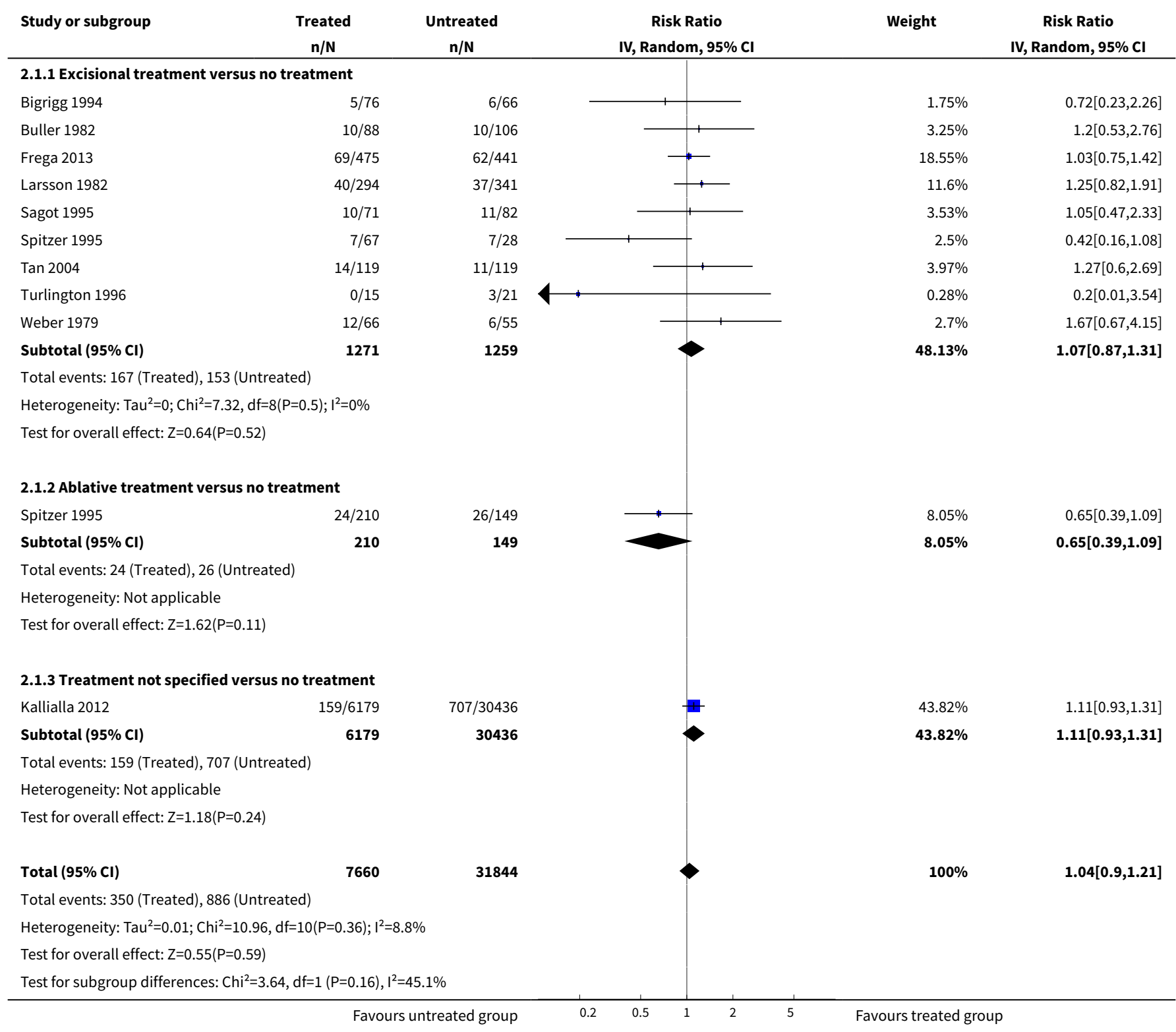


Analysis 2.2. Comparison 2 Early pregnancy outcomes, Outcome 2 Miscarriage rates (treatment versus no treatment).

\begin{tabular}{lrr} 
Study or subgroup & $\begin{array}{c}\text { Treated } \\
\mathbf{n} / \mathbf{N}\end{array}$ & $\begin{array}{c}\text { Untreated } \\
\mathbf{n} / \mathbf{N}\end{array}$ \\
\hline $\mathbf{2 . 2 . 1}$ CKC versus no treatment & & \\
Buller 1982 & $10 / 88$ & $10 / 106$ \\
Larsson 1982 & $40 / 294$ & $37 / 341$ \\
Weber 1979 & $12 / 66$ & $6 / 55$ \\
Subtotal $(\mathbf{9 5 \%} \mathbf{~ C l})$ & $\mathbf{4 4 8}$ & $\mathbf{5 0 2}$
\end{tabular}

Total events: 62 (Treated), 53 (Untreated)

Heterogeneity: $\mathrm{Tau}^{2}=0 ; \mathrm{Chi}^{2}=0.35, \mathrm{df}=2(\mathrm{P}=0.84) ; \mathrm{I}^{2}=0 \%$

Test for overall effect: $\mathrm{Z}=1.47(\mathrm{P}=0.14)$

\subsubsection{LLETZ/LEEP versus no treatment}

Bigrigg 1994

Frega 2013

$5 / 76$

$69 / 475$

Tan 2004

$14 / 119$

Turlington 1996

$0 / 15$

Subtotal $(95 \% \mathrm{Cl})$

685

Total events: 88 (Treated), 82 (Untreated)

Heterogeneity: $\mathrm{Tau}^{2}=0 ; \mathrm{Chi}^{2}=1.94, \mathrm{df}=3(\mathrm{P}=0.59) ; \mathrm{I}^{2}=0 \%$

Test for overall effect: $\mathrm{Z}=0.17(\mathrm{P}=0.86)$

\subsubsection{Laser conisation versus no treatment}

Sagot 1995

Spitzer 1995

$10 / 71$

Subtotal $(95 \% \mathrm{Cl})$

Total events: 17 (Treated), 18 (Untreated)

Heterogeneity: $\mathrm{Tau}^{2}=0.22 ; \mathrm{Chi}^{2}=2.12, \mathrm{df}=1(\mathrm{P}=0.15) ; \mathrm{I}^{2}=52.9 \%$

Test for overall effect: $\mathrm{Z}=0.81(\mathrm{P}=0.42)$

\subsubsection{Laser ablation versus no treatment}

Spitzer 1995

Subtotal $(95 \% \mathrm{Cl})$

$\mathbf{2 1 0}$

$26 / 149$

149

$6 / 66$
$62 / 441$
$11 / 119$
$3 / 21$
647

$6 / 55$

502

\begin{tabular}{cc}
$\begin{array}{c}\text { Risk Ratio } \\
\text { IV, Random, } 95 \% \text { Cl }\end{array}$ & Weight \\
\hline
\end{tabular}

\begin{tabular}{l|l}
\hline \\
\hline \\
\hline
\end{tabular}

$1.75 \%$

$18.55 \%$

$3.97 \%$

$0.28 \%$

$\mathbf{2 4 . 5 5 \%}$

$3.25 \% \quad 1.2[0.53,2.76]$

$11.6 \%$

$1.25[0.82,1.91]$

$1.67[0.67,4.15]$

$17.56 \%$

$1.3[0.92,1.83]$

$11 / 82$

$7 / 28$

110

$3.53 \%$

$1.05[0.47,2.33]$

$0.42[0.16,1.08]$

$2.5 \%$

$0.69[0.28,1.69]$

Total events: 24 (Treated), 26 (Untreated)

Heterogeneity: Not applicable

Test for overall effect: $Z=1.62(P=0.11)$

2.2.5 Treatment not specified versus no treatment

Kallialla 2012

$159 / 6179$

Subtotal $(95 \% \mathrm{Cl})$

6179

Total events: 159 (Treated), 707 (Untreated)

Heterogeneity: Not applicable

Test for overall effect: $\mathrm{Z}=1.18(\mathrm{P}=0.24)$

Total $(95 \% \mathrm{Cl})$

Total events: 350 (Treated), 886 (Untreated) 
Analysis 2.3. Comparison 2 Early pregnancy outcomes, Outcome 3 1st trimester Miscarriage rates (treatment versus no treatment).

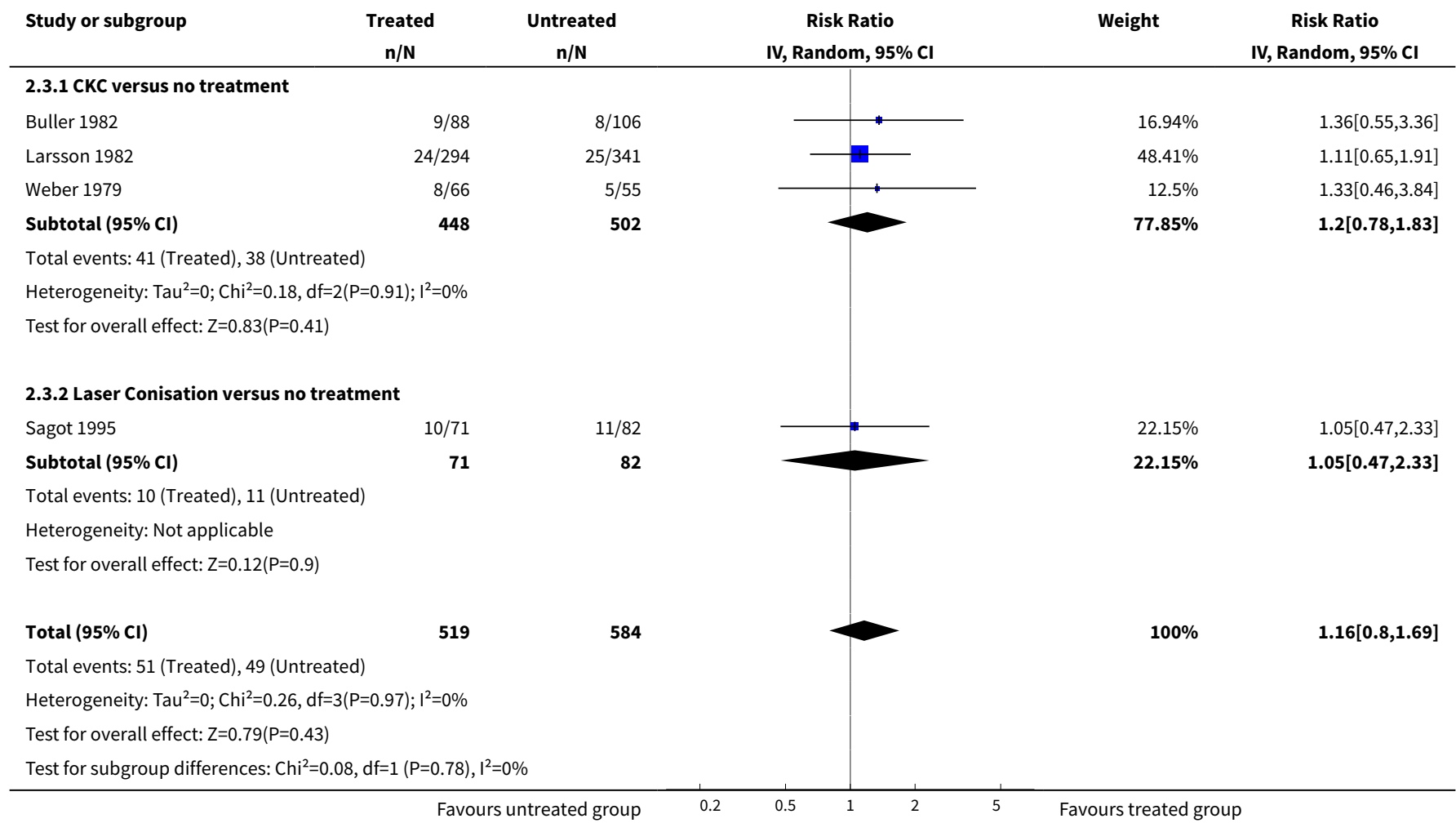

Analysis 2.4. Comparison 2 Early pregnancy outcomes, Outcome 4 2nd trimester miscarriage rates (treatment versus no treatment).

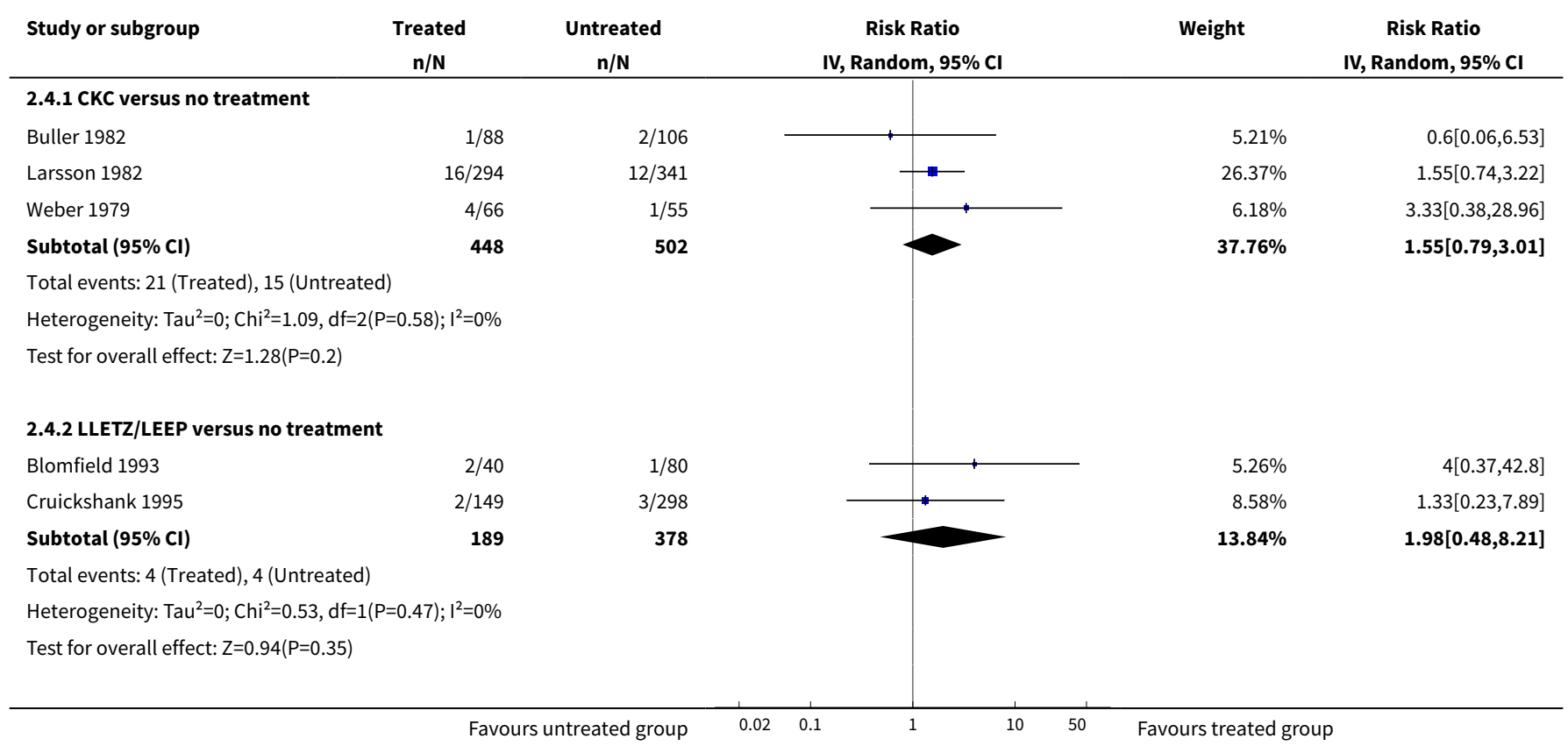




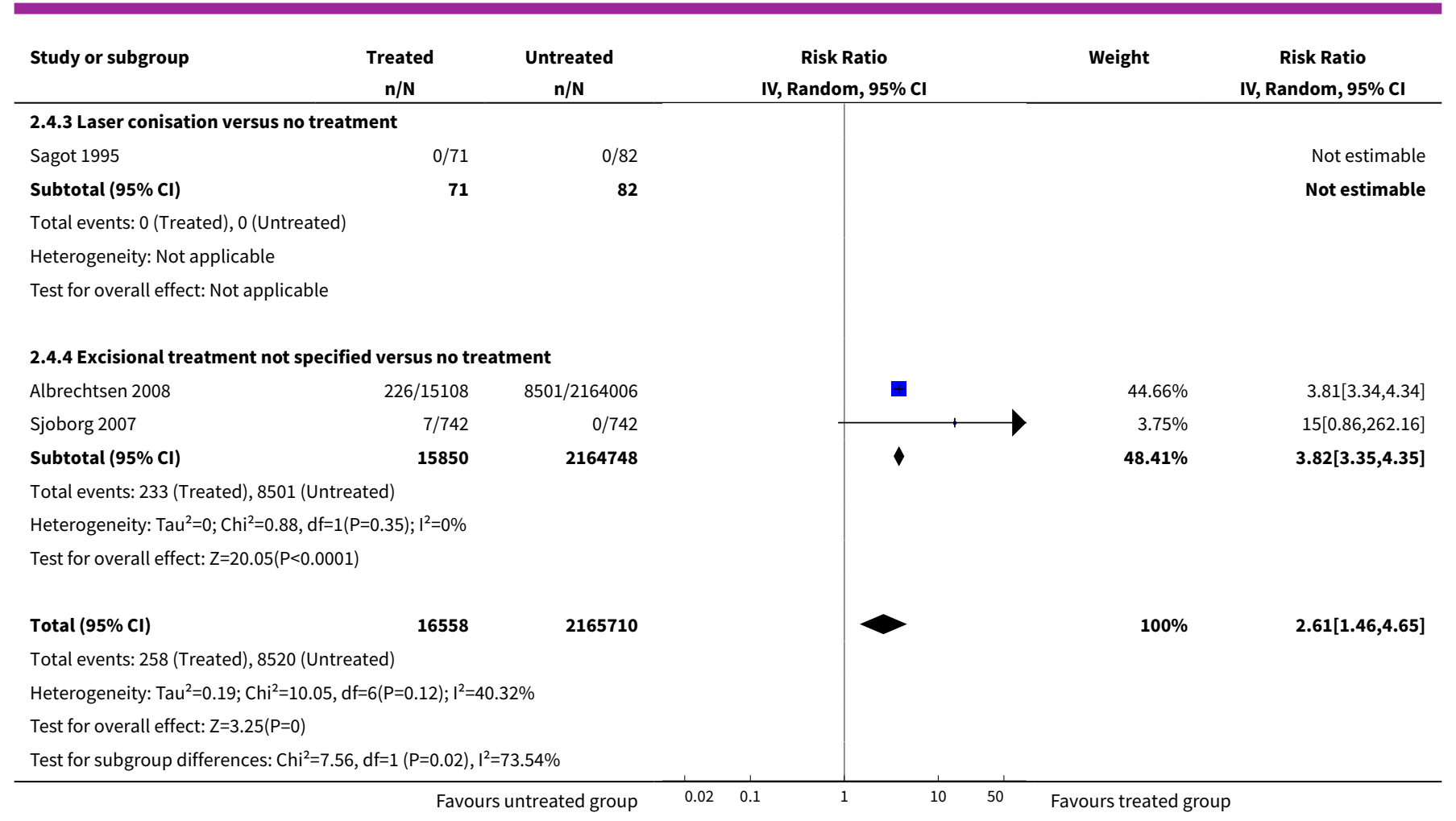

Analysis 2.5. Comparison 2 Early pregnancy outcomes, Outcome 5 Ectopic pregnancy (treatment versus no treatment).

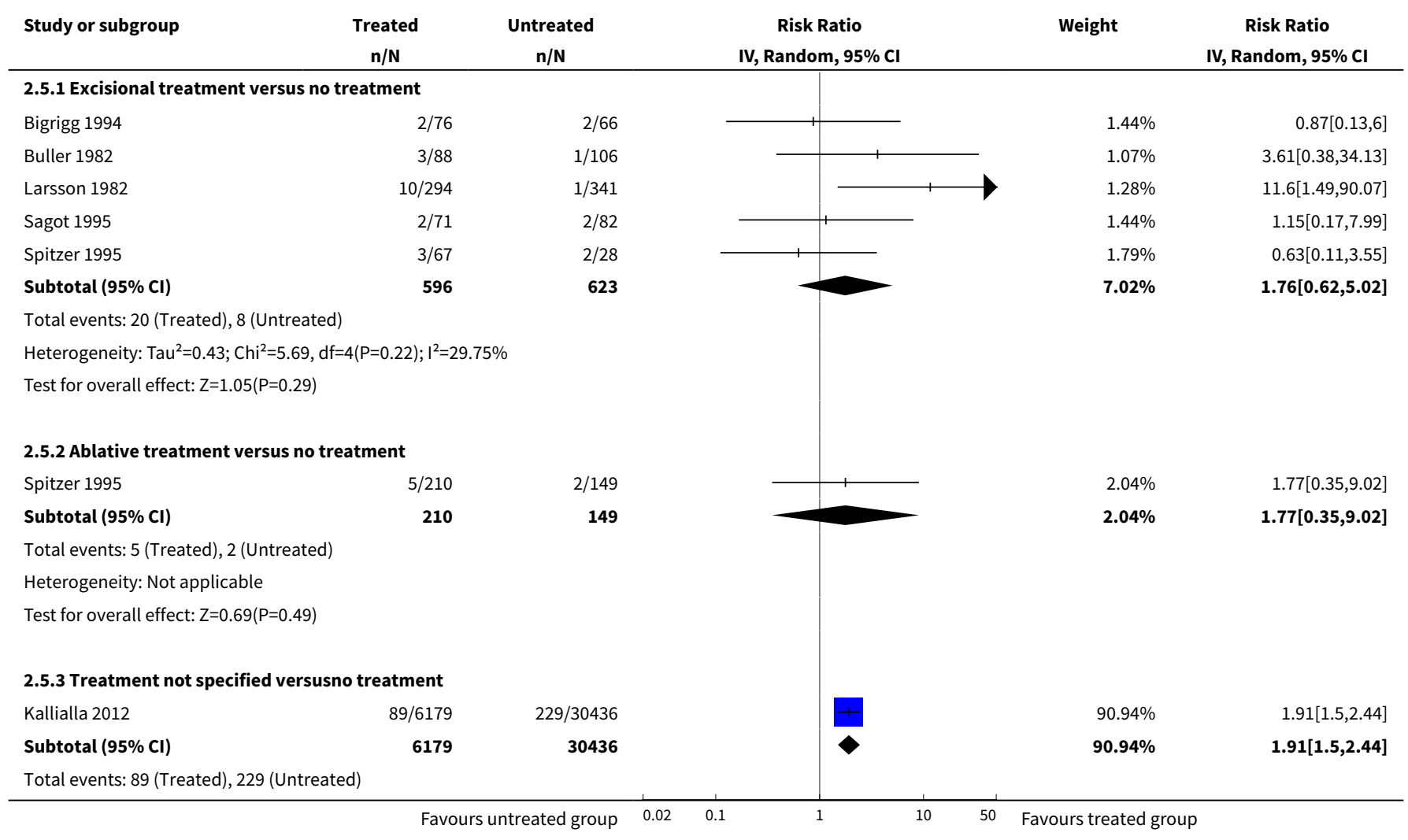




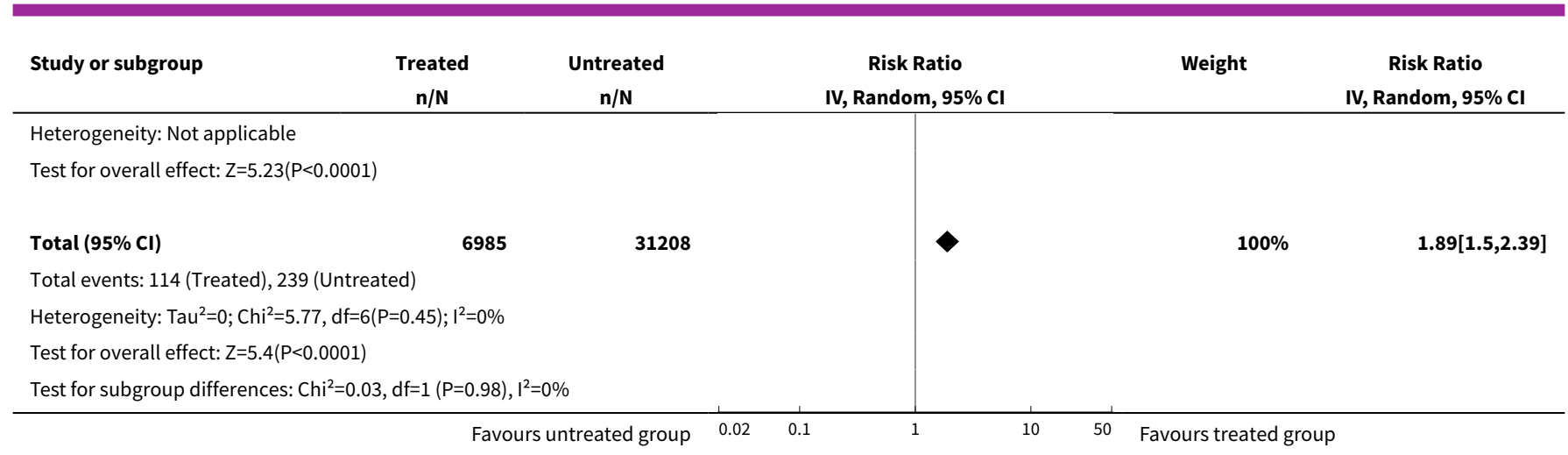

Analysis 2.6. Comparison 2 Early pregnancy outcomes, Outcome 6 Ectopic pregnancy (treatment versus no treatment).

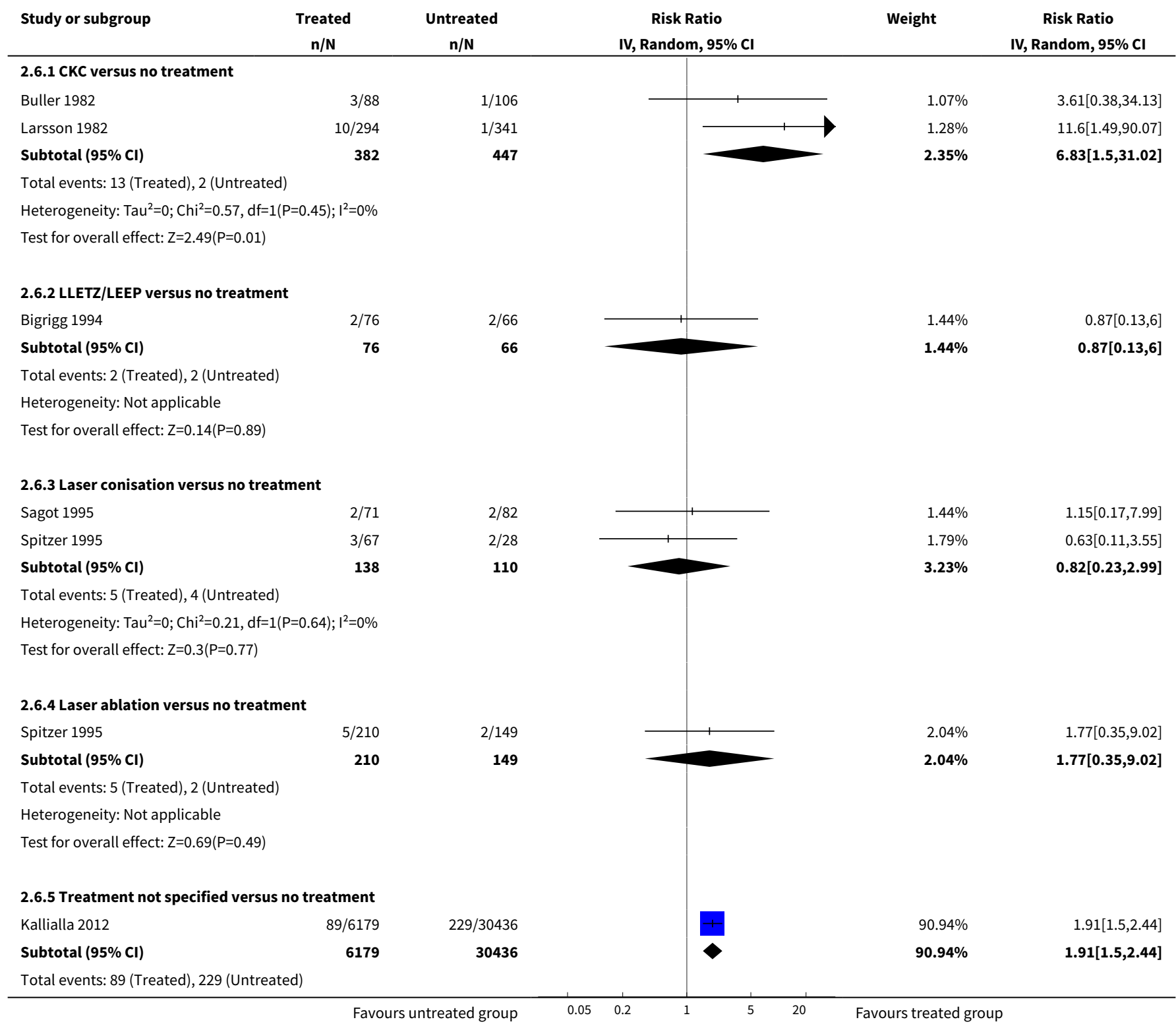




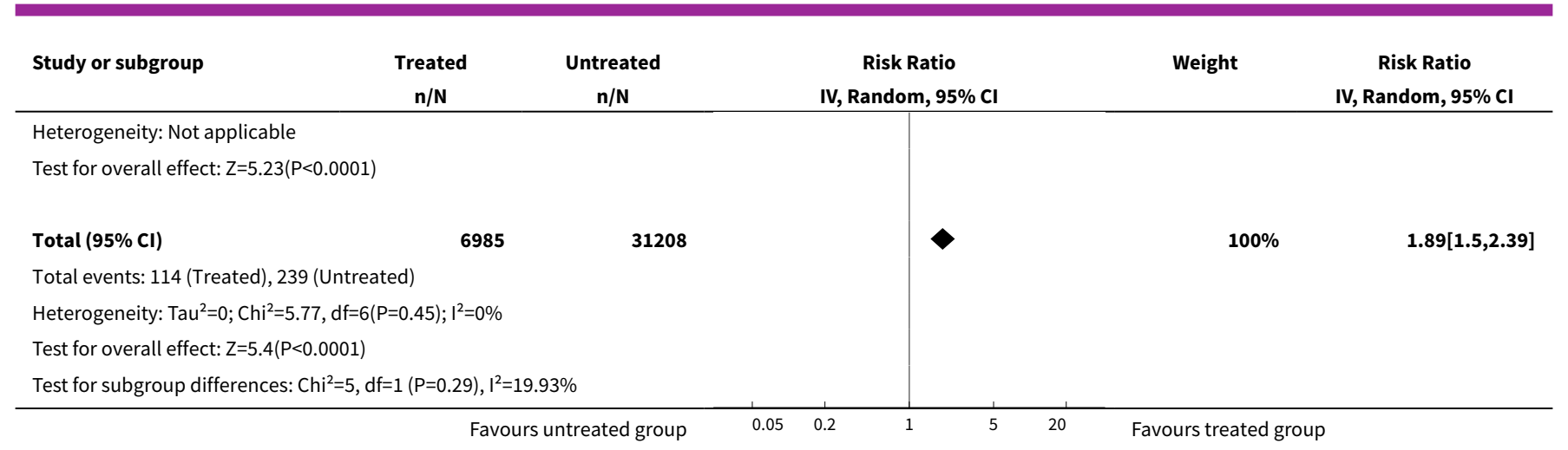

\section{Analysis 2.7. Comparison 2 Early pregnancy outcomes, Outcome 7 Molar pregnancy rates (treatment versus no treatment).}

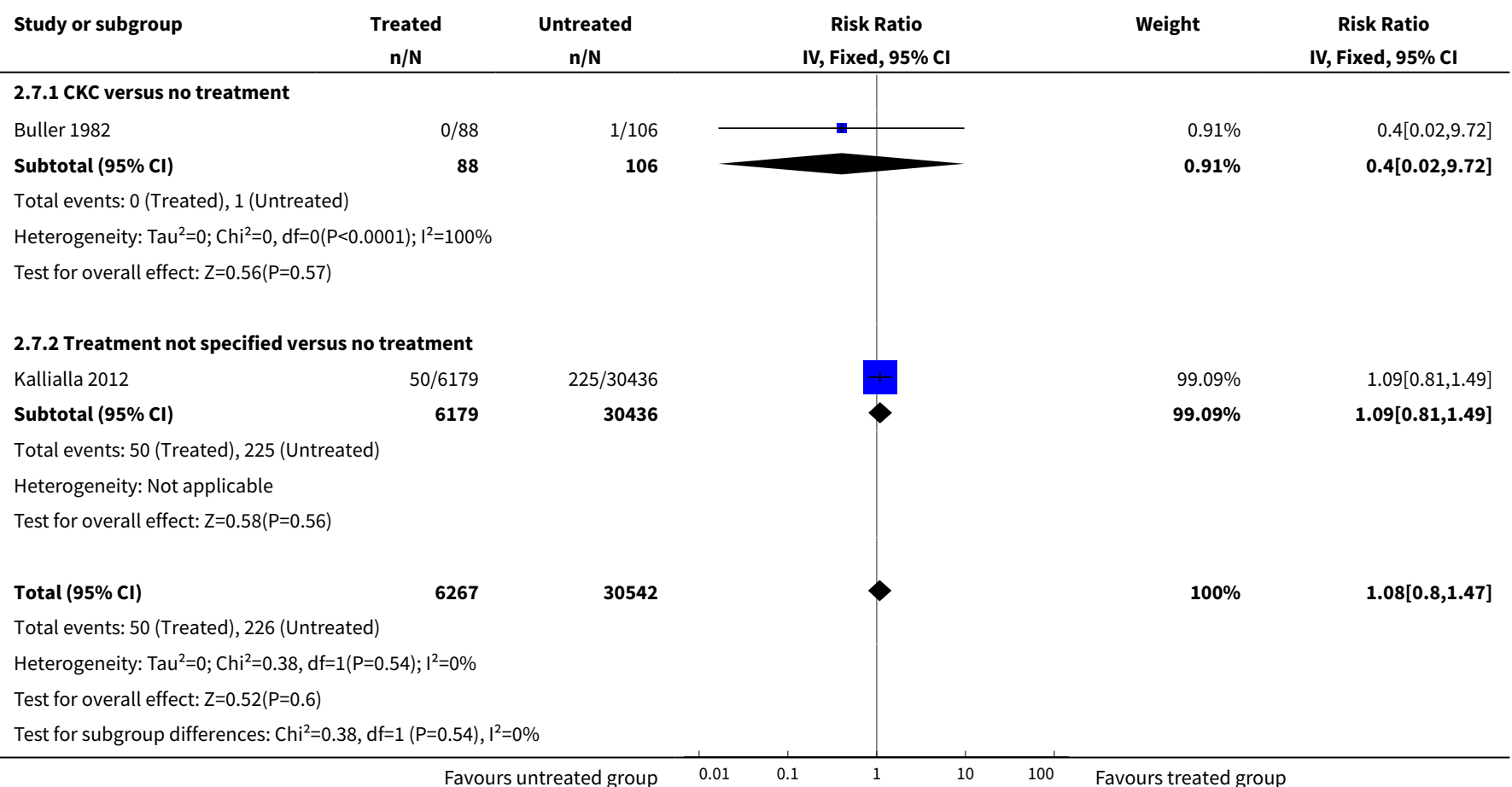

Analysis 2.8. Comparison 2 Early pregnancy outcomes, Outcome 8 Termination of pregnancy rates (Treatment versus no treatment).

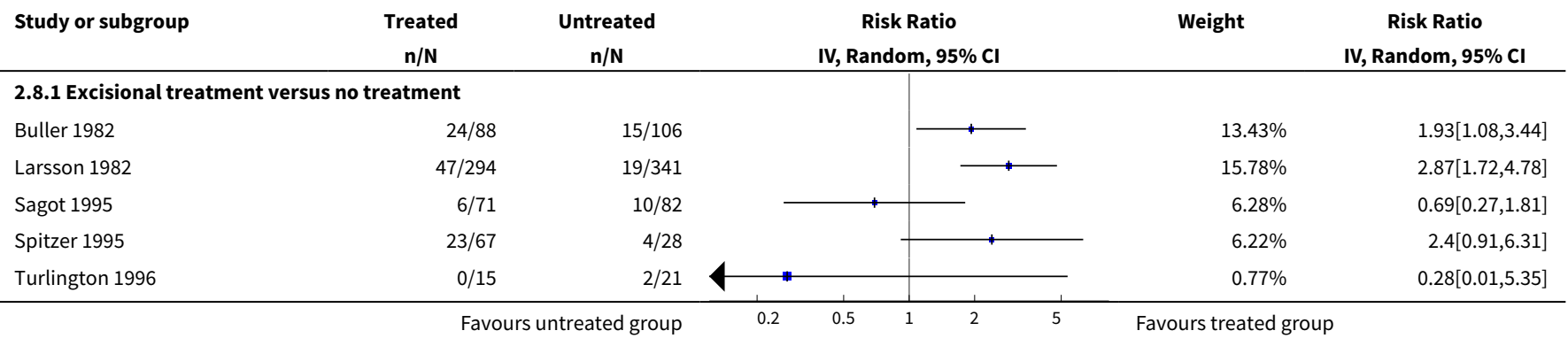




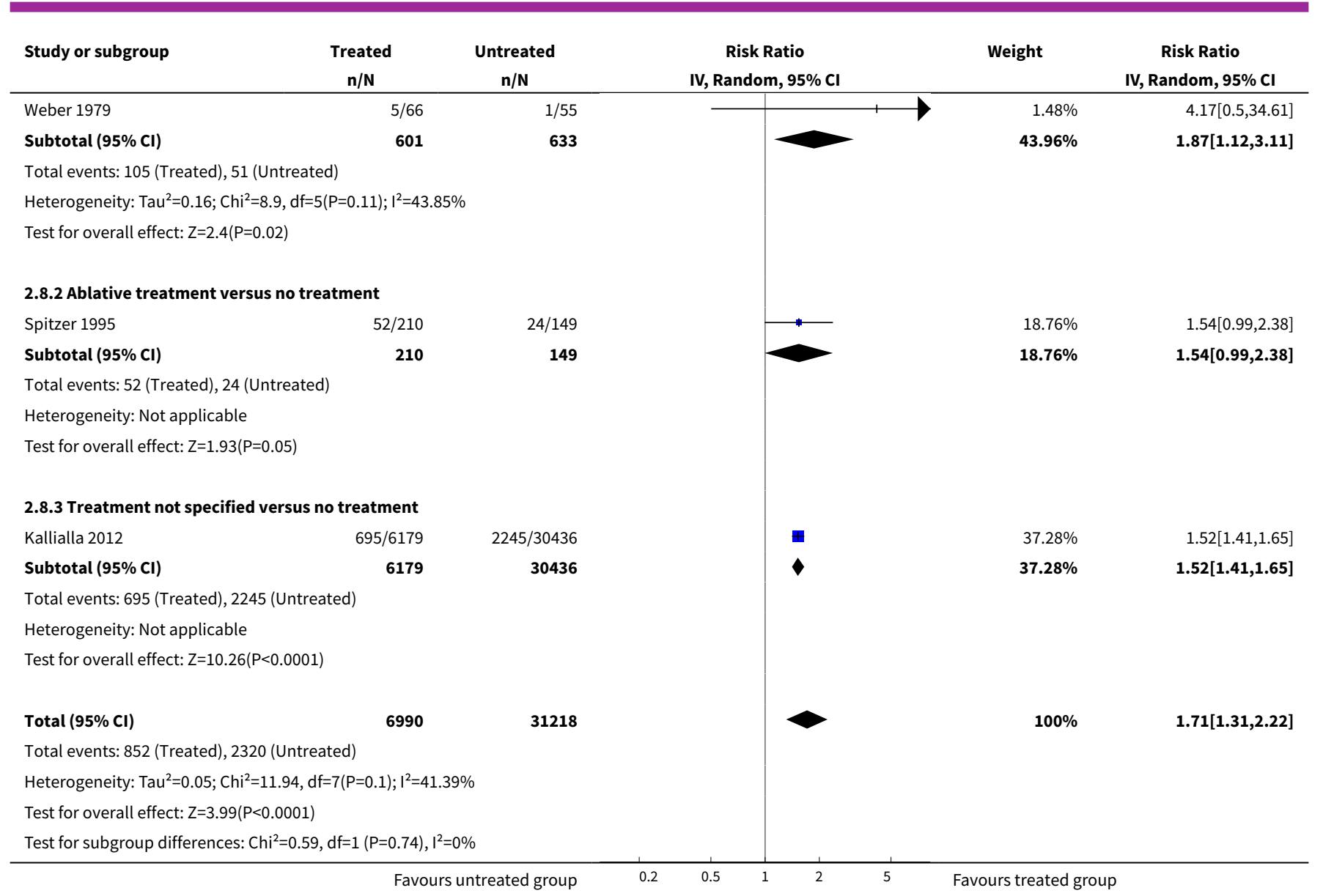

Analysis 2.9. Comparison 2 Early pregnancy outcomes, Outcome 9 Termination of pregnancy rates (treatment versus no treatment).

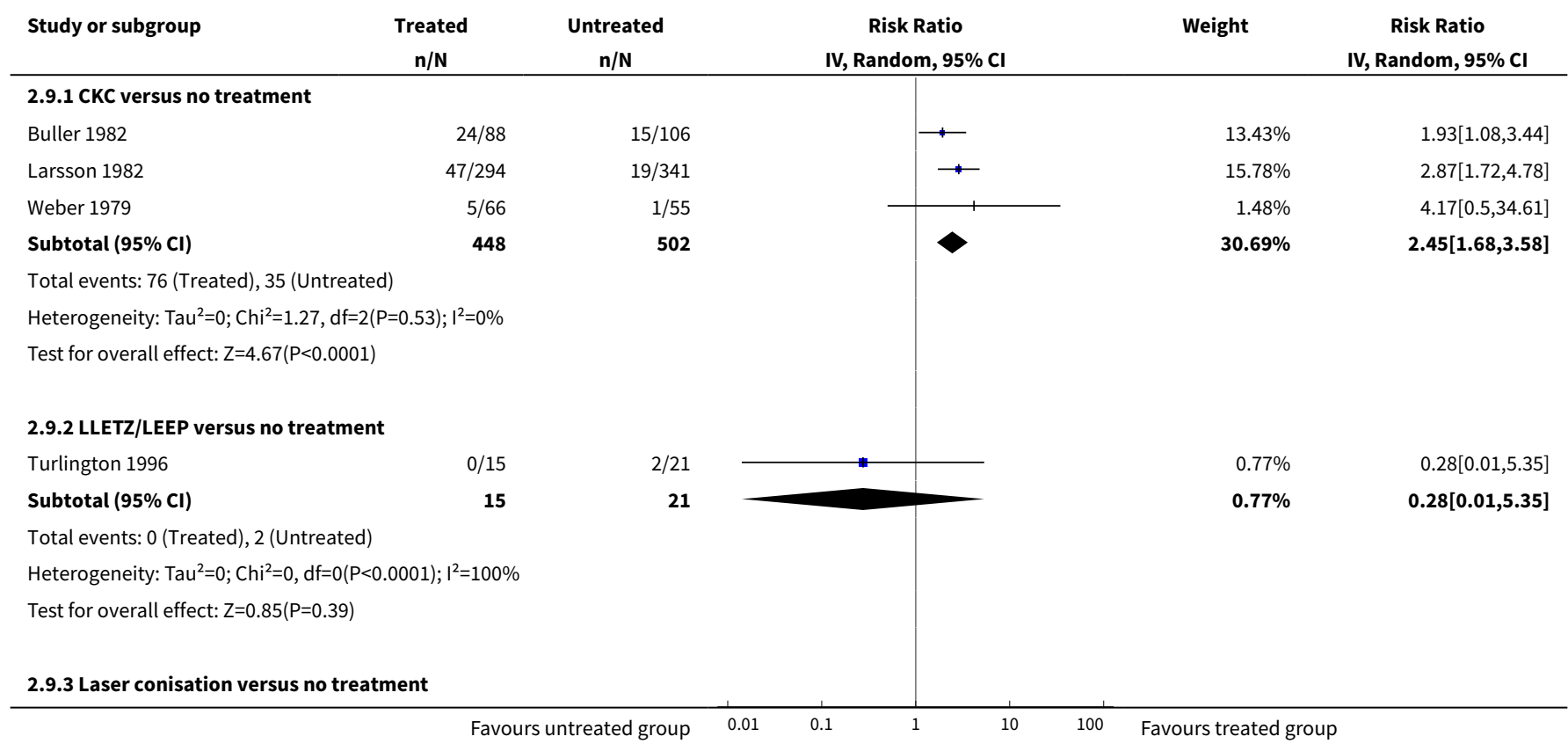




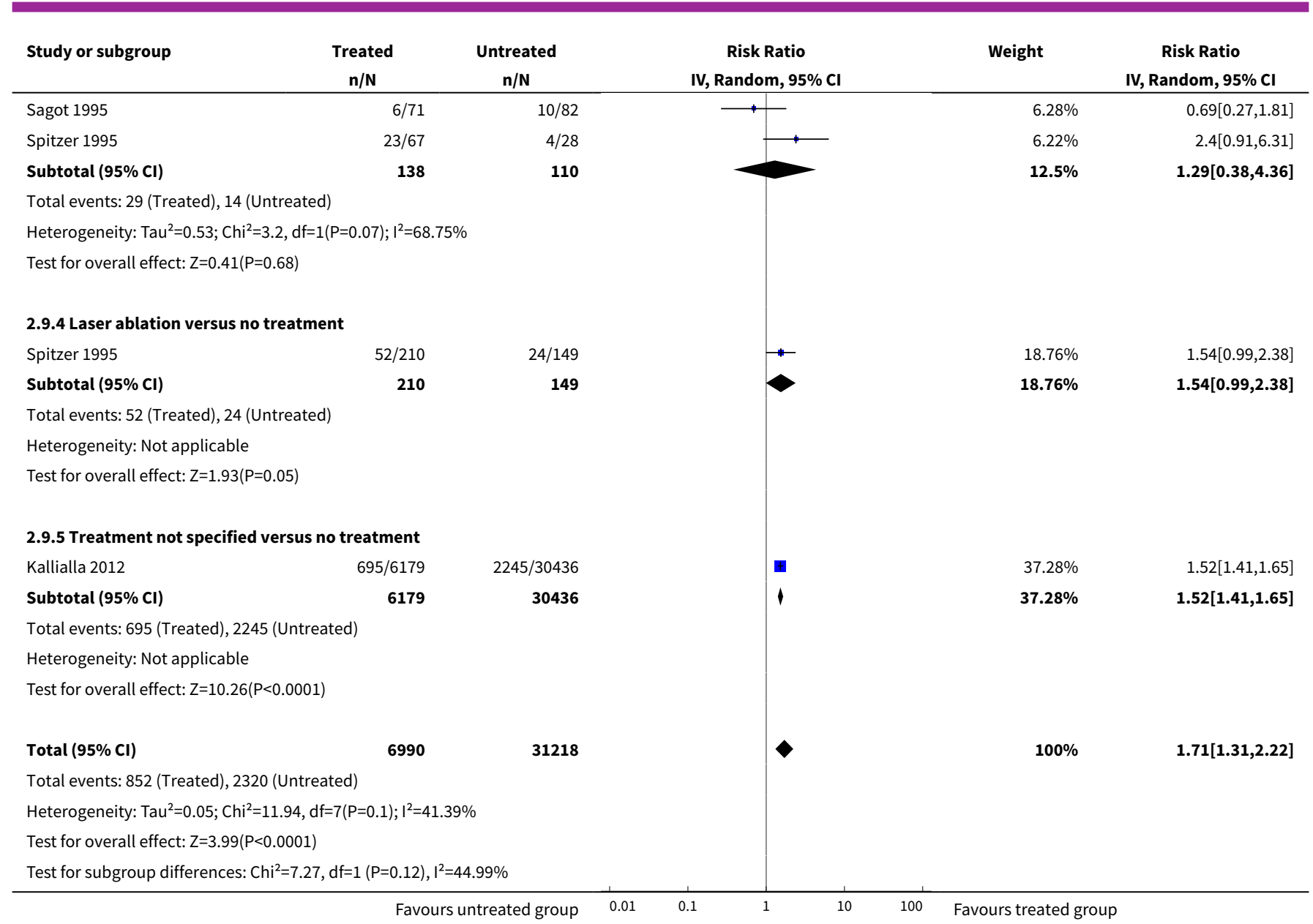

\section{APPENDICES}

\section{Appendix 1. MEDLINE Search Strategy}

1 exp Uterine Cervical Neoplasms/

2 (cervi ${ }^{\star}$ and (cancer* or tumor $^{\star}$ or tumour ${ }^{\star}$ or neoplas* or malignan* or carcinom $\left.^{\star}\right)$ ).mp.

3 exp Cervical Intraepithelial Neoplasia/

4 CIN.mp.

$5\left(\right.$ cervi $^{\star}$ and (intraepithel ${ }^{\star}$ or epithel ${ }^{\star}$ or dysplasia or pre-cancer ${ }^{\star}$ or precancer $\left.{ }^{\star}\right)$ ).mp.

6 or $1-5$

7 exp Conization/

8 (conisation or conization).mp.

9 exp Laser Therapy/

10 laser.mp.

11 exp Cryotherapy/

12 cryotherapy.mp.

13 cold coagulation.mp.

14 exp Diathermy/

15 diatherm ${ }^{\star} . \mathrm{mp}$.

16 cone biopsy.mp.

17 loop.mp.

18 LLETZ.mp.

19 LEEP.mp.

20 ablat $^{\star} . \mathrm{mp}$.

21 excision*.mp.

Fertility and early pregnancy outcomes after conservative treatment for cervical intraepithelial neoplasia (Review) 
22 transformation zone.mp.

23 (CKC or LA or LC or CC or RD or TZ).mp.

24 (conservative and (method ${ }^{\star}$ or treatment $^{\star}$ or intervention $^{\star}$ or management)).mp.

25 or/7-24

266 and 25

27 exp Premature Birth/

28 (preterm or premature).mp.

29 exp Infant, Low Birth Weight/

30 birth weight.mp.

31 Perinatal Mortality/

32 perinatal mortality. $\mathrm{mp}$.

33 exp Intensive Care, Neonatal/

34 (neonatal and intensive care).mp.

35 exp Fertility/

36 fertil $^{\star} . \mathrm{mp}$.

37 conception.mp.

38 exp Pregnancy/

39 pregnancy.mp.

40 gestation ${ }^{\star} . \mathrm{mp}$.

41 exp Abortion, Spontaneous/

42 miscarriage*.mp.

43 exp Cesarean Section/

44 (cesarean or caesarean).mp.

45 exp Obstetric Labor, Premature/

46 exp Labor, Obstetric/

47 (labor or labour).mp.

48 Fetal Membranes, Premature Rupture/

49 pPROM.mp.

50 or/ $27-49$

5126 and 50

key:

$\mathrm{mp}=$ title, original title, abstract, name of substance word, subject heading word

\section{Appendix 2. EMBASE Search Strategy}

1 exp uterine cervix tumor/

2 (cervi ${ }^{\star}$ and (cancer ${ }^{\star}$ or tumor ${ }^{\star}$ or tumour ${ }^{\star}$ or neoplas ${ }^{\star}$ or malignan ${ }^{\star}$ or carcinom $\left.\left.{ }^{\star}\right)\right) . m p$.

3 uterine cervix carcinoma in situ/

4 CIN.mp.

5 (cervi ${ }^{\star}$ and (intraepithel ${ }^{*}$ or epithel ${ }^{*}$ or dysplasia or pre-cancer ${ }^{\star}$ or precancer $\left.\left.^{\star}\right)\right) . \mathrm{mp}$.

6 or/1-5

7 uterine cervix conization/

8 (conisation or conization).mp.

9 low level laser therapy/

10 laser.mp.

11 exp cryotherapy/

12 cryotherapy.mp.

13 cold coagulation.mp.

14 diathermy/

15 diatherm ${ }^{\star} . \mathrm{mp}$.

16 cone biopsy.mp.

17 loop.mp.

18 LLETZ.mp.

19 LEEP.mp.

20 ablat $^{\star} . \mathrm{mp}$

21 excision*.mp.

22 transformation zone.mp.

23 (CKC or LA or LC or CC or RD or TZ).mp.

24 (conservative and (method* ${ }^{\star}$ or treatment* or intervention* or management)).mp.

25 or/ $7-24$

266 and 25

Fertility and early pregnancy outcomes after conservative treatment for cervical intraepithelial neoplasia (Review) 
27 prematurity/

28 (preterm or premature).mp.

29 exp low birth weight/

30 birth weight.mp.

31 perinatal mortality/

32 perinatal mortality.mp.

33 newborn intensive care/

34 (neonat* $^{\star}$ and intensive care).mp.

35 female fertility/

36 fertil $^{\star}$.mp.

37 conception/

38 conception.mp.

39 exp pregnancy/

40 pregnancy.mp.

41 gestation ${ }^{\star} . \mathrm{mp}$.

42 spontaneous abortion/

43 miscarriage ${ }^{\star} . \mathrm{mp}$.

44 cesarean section/

45 (cesarean or caesarean).mp.

46 premature labor/

47 (labor or labour).mp.

48 premature fetus membrane rupture/

49 pPROM.mp.

50 or/27-49

5126 and 50

key:

$\mathrm{mp}=$ title, abstract, subject headings, heading word, drug trade name, original title, device manufacturer, drug manufacturer name

\section{Appendix 3. CENTRAL search strategy}

\#1 MeSH descriptor Uterine Cervical Neoplasms explode all trees

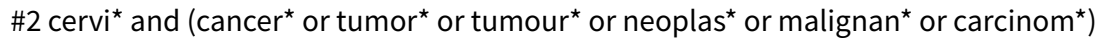

\#3 MeSH descriptor Cervical Intraepithelial Neoplasia explode all trees

\#4 CIN

$\# 5$ cervi $^{\star}$ and (intraepithel ${ }^{\star}$ or epithel ${ }^{\star}$ or dysplasia or pre-cancer ${ }^{\star}$ or precancer $^{\star}$ )

\#6 (\#1 OR \#2 OR \#3 OR \#4 OR \#5)

$\# 7 \mathrm{MeSH}$ descriptor Conization explode all trees

\#8 conisation or conization

\#9 MeSH descriptor Laser Therapy explode all trees

\#10 laser

\#11 MeSH descriptor Cryotherapy explode all trees

\#12 cryotherapy

$\# 13$ cold coagulation

\#14 MeSH descriptor Diathermy explode all trees

\#15 diatherm*

\#16 cone biopsy

\#17 loop

\#18 LLETZ

\#19 LEEP

\#20 ablat*

\#21 excision*

\#22 transformation zone

\#23 CKC or LA or LC or CC or RD or TZ

$\# 24$ conservative and (method* or treatment* or intervention* or management)

\#25 (\#7 OR \#8 OR \#9 OR \#10 OR \#11 OR \#12 OR \#13 OR \#14 OR \#15 OR \#16 OR \#17 OR \#18 OR \#19 OR \#20 OR \#21 OR \#22 OR \#23 OR \#24)

\#26 (\#6 AND \#25)

\#27 MeSH descriptor Premature Birth explode all trees

\#28 preterm or premature

\#29 MeSH descriptor Infant, Low Birth Weight explode all trees

\#30 birth weight

\#31 MeSH descriptor Perinatal Mortality explode all trees

Fertility and early pregnancy outcomes after conservative treatment for cervical intraepithelial neoplasia (Review) 
\#32 perinatal mortality

\#33 MeSH descriptor Intensive Care, Neonatal explode all trees

\#34 neonat* and (intensive care)

\#35 MeSH descriptor Fertility explode all trees

\#36 fertil*

\#37 conception

\#38 MeSH descriptor Pregnancy explode all trees

\#39 pregnancy

\#40 gestation*

\#41 MeSH descriptor Abortion, Spontaneous explode all trees

\#42 miscarriage*

\#43 MeSH descriptor Cesarean Section explode all trees

\#44 cesarean or caesarean

\#45 MeSH descriptor Obstetric Labor, Premature explode all trees

\#46 MeSH descriptor Labor, Obstetric explode all trees

\#47 labor or labour

\#48 MeSH descriptor Fetal Membranes, Premature Rupture explode all trees

\#49 pPROM

\#50 (\#27 OR \#28 OR \#29 OR \#30 OR \#31 OR \#32 OR \#33 OR \#34 OR \#35 OR \#36 OR \#37 OR \#38 OR \#39 OR \#40 OR \#41 OR \#42 OR \#43 OR \#44 OR \#45 OR \#46 OR \#47 OR \#48 OR \#49)

\#51 (\#26 AND \#50) 


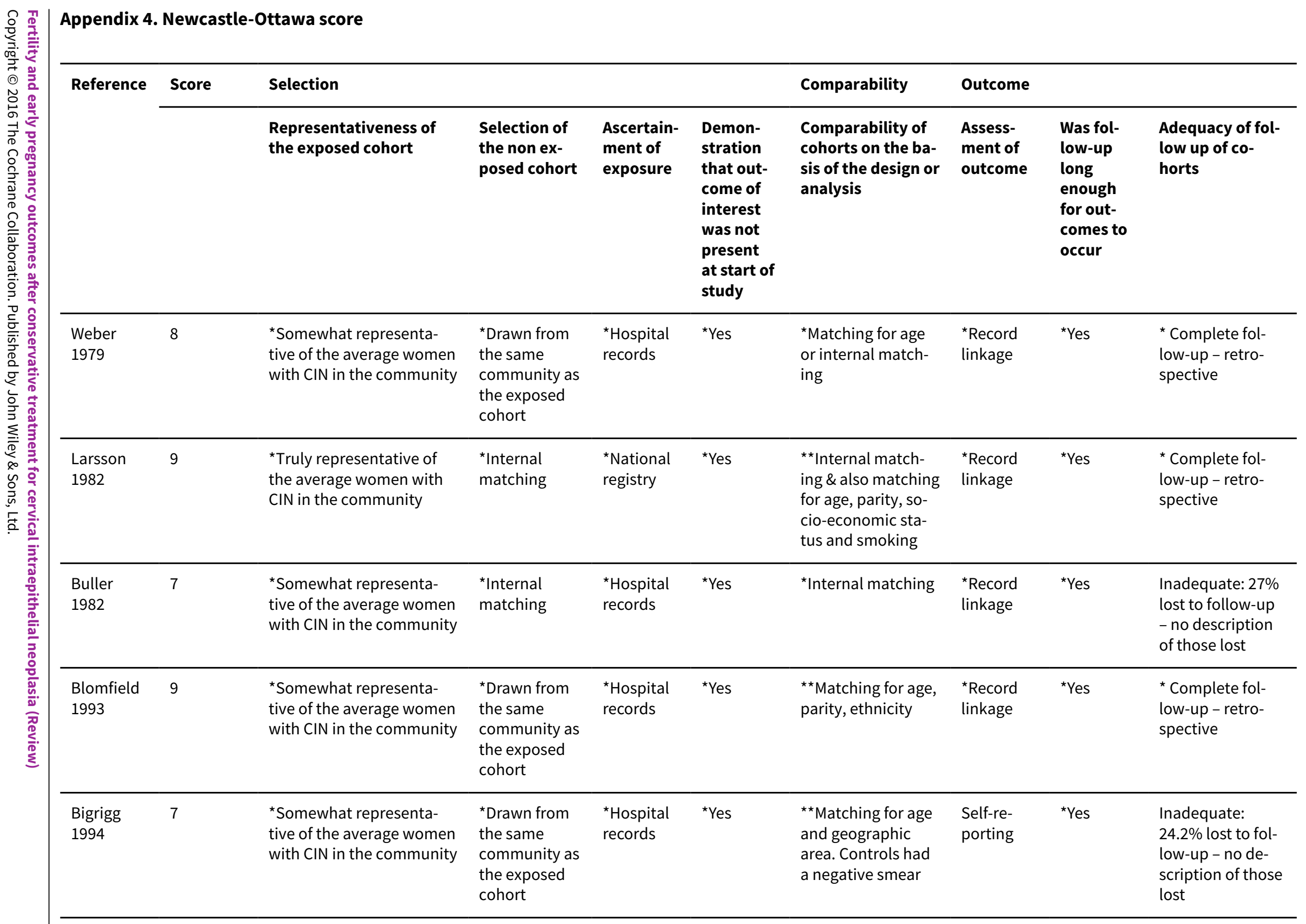




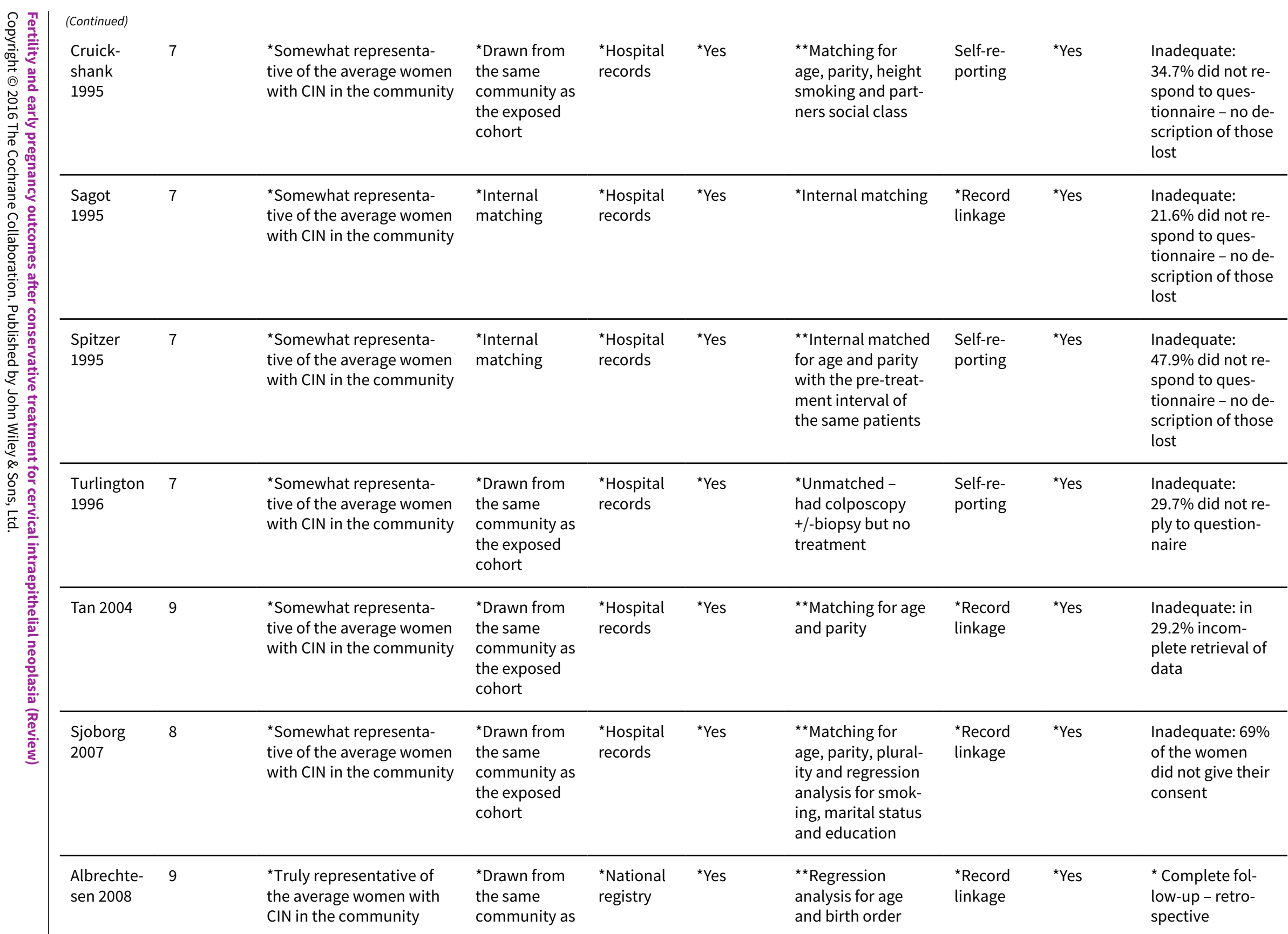




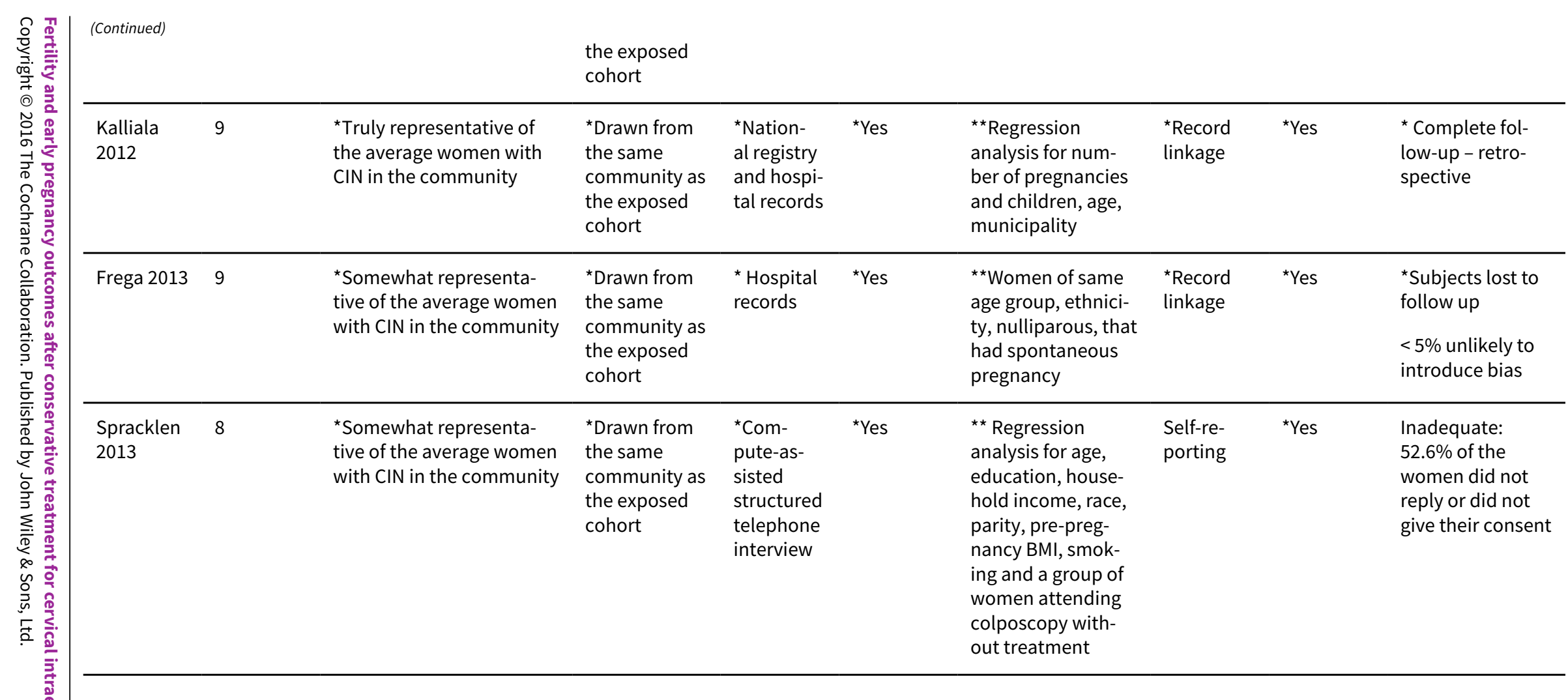




\section{Appendix 5. List of abbreviations}

CENTRAL: Cochrane Central Register of Controlled Trials

CKC: cold knife conisation

$\mathrm{Cl}$ : (95\%) confidence interval

$\mathrm{CIN}$ : cervical intraepithelial neoplasia

CC: cold coagulation

CT: cryotherapy

LA: laser ablation

LC: laser conisation

LEEP: loop electrosurgical excision procedure

LLETZ: large loop excision of the transformation zone

NE: not estimable

NETZ: needle excision of the transformation zone

NOS: not otherwise specified

RCT: randomised controlled trial

$\mathrm{RD}$ : radical diathermy

RR: relative risk

SWETZ: straight wire excision of the transformation zone

TOP: Termination of pregnancy

TZ: transformation zone

\section{Appendix 6. List of definitions}

First trimester miscarriage: miscarriage less than 12 weeks of gestation

Second trimester miscarriage: miscarriage between 13 and 24 weeks of gestation

WHAT'S NEW

\begin{tabular}{lll}
\hline Date & Event & Description \\
\hline 21 September 2016 & Amended & Contact details updated. \\
\hline
\end{tabular}

\section{H I S T O R Y}

Protocol first published: Issue 4, 2010

Review first published: Issue 9, 2015

\begin{tabular}{lll}
\hline Date & Event & Description \\
\hline 21 September 2015 & Amended & Co-author contact details amended. \\
\hline
\end{tabular}

\section{CONTRIBUTIONS OF AUTHORS}

The study was conceived and designed by MK, PB and EP. The data was acquired and collated by MK, AM, AA and MP and analysed by MK, AM and MA. MA provided methodological support. The manuscript was drafted and revised critically for important intellectual content by all authors. All authors gave final approval of the version to be published and have contributed to the manuscript. PB and EP are joint last authors.

\section{DECLARATIONS OF INTEREST}

The authors have no conflicts of interest to declare. 


\section{SOURCESOF SUPPORT}

\section{Internal sources}

- Gynaecological Cancer Cochrane Review Collaboration, UK.

Unit Cancer Epidemiology received financial support for conducting meta-analyses on questions related to cervical cancer prevention.

\section{External sources}

- Seventh Framework Programme of DG Research of the European Commission, Belgium.

MA received support from the COHEAHR Network (Grant No 603019), coordinated by the Free University of Amsterdam (the Netherlands) as leader of the working package "Meta-Analysis".

- Institut National du Cancer, France.

MA received support from the COSPCC study (Conséquences obstétricales du (sur)traitement des précurseurs du cancer du col utérin), a collaboration between the Univeristy of Amiens and four other French universities (Angers, Marseille, Paris, Strassbourg) with the Scientific Institute of Public Health (Brussels), involving an individual-patient data meta-analysis.

- European Federation of Colposcopy, UK.

MA received support to the Unit Cancer Epidemiology (IPH, Brussels) to conduct systematic reviews on the quality, safety and effectiveness of the diagnosis and treatment of cervical precancer.

- NIHR Biomedical Research Centre, UK.

The study and the authors (MK, AM, PB) were supported by the Imperial Healthcare NHS Trust Biomedical Research Council grant P45272.

- BSCCP Jordan/Singer Research Award, UK.

MK was supported by the British Society of Colposcopy and Cervical Pathology (BSCCP) Jordan/Singer Award.

- Imperial College Healthcare Charity Fellowship, UK.

AM and MK were supported by the Imperial College Healthcare Charity Fellowship.

\section{DIFFERENCES BETWEEN PROTOCOLANDREVIEW}

The original protocol was drafted to analyse fertility, early pregnancy and obstetric outcomes in women with a history of treatment for CIN versus untreated controls. Due to the clinical difference of the outcomes and the large number of studies, interventions and outcomes, it was decided to split the review into two. This review addresses the impact of treatment on fertility and early pregnancy outcomes and the second review will address obstetric outcomes. The type of participants section is altered to reflect the focus of this review which is fertility and early pregnancy outcomes after the original protocol was split. We also included a treatment technique called NETZ or SWETZ as they are a variation of LLETZ/LEEP.

We intended to assess the risk of publication bias (Steichen 1998), the analysis for small study effects and other potential sources of heterogeneity for each individual meta-analysis, however due to the small number of studies this could not be formally assessed.

\section{N DEX TERMS}

\section{Medical Subject Headings (MeSH)}

*Fertility; *Pregnancy Outcome; Abortion, Spontaneous [epidemiology]; Case-Control Studies; Cervical Intraepithelial Neoplasia [*surgery]; Pregnancy Rate; Retrospective Studies

\section{MeSH check words}

Female; Humans; Pregnancy 